\title{
A political economy approach to measuring EU food standard enforcement and their implications on agri- food trade
}

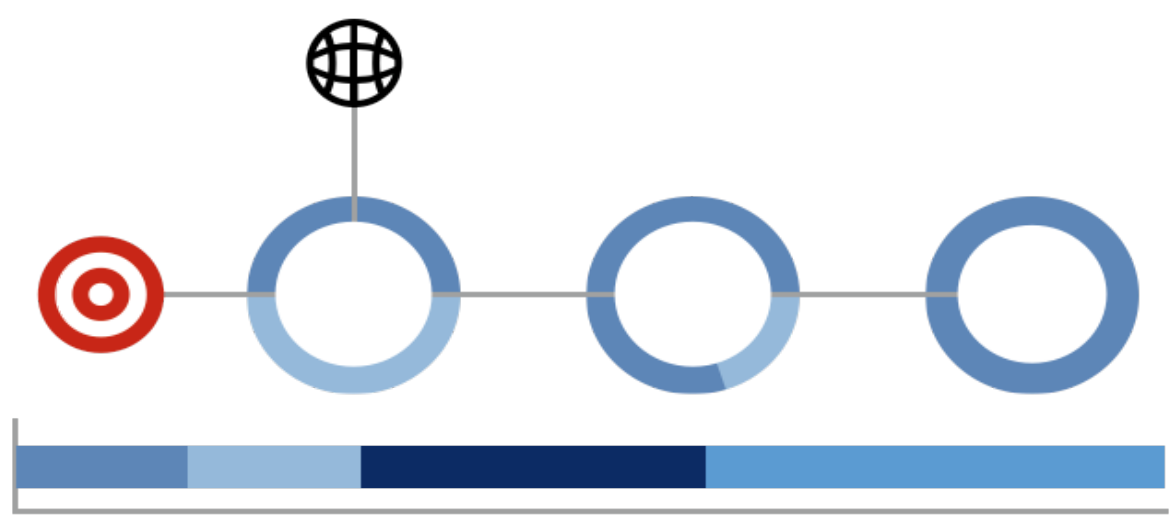

Doctoral Thesis

By

\section{Ibtissem Taghouti}

Under the supervision of

Dr. José Maria Garcia-Alvarez-Coque

Dr. Victor Martinez-Gomez

Dr. Mohamed Elloumi 


\title{
A political economy approach to measuring EU food standard enforcement and their implications on agri- food trade
}

Doctoral Thesis

By

\section{Ibtissem Taghouti}

Under the supervision of

\author{
Dr. José Maria Garcia-Alvarez-Coque \\ Dr. Victor Martinez-Gomez \\ Dr. Mohamed Elloumi
}




\section{Acknowledgments}

I would like to express my sincere thanks to many people and institutions that have helped me to achieve my academic goals and who deserve my acknowledgment.

First among those I want to thank is my supervisor Dr. José Maria Garcia-AlvarezCoque, I would like to express my deepest thanks and gratitude for his supervision, insightful guidance, encouragement, constructive criticism and friendly treatment throughout my $\mathrm{PhD}$ study. Without his guidance, this dissertation would not have been accomplished. I am honored to have learned from his innumerable lessons and insights in the academic research. I owe you so much.

I am very thankful for Dr. Victor Martinez-Gomez for his valuable advice, support, encouragement and friendly treatment throughout this Thesis. I am grateful for his time and effort spent in reviewing this research.

I would also like to thank Dr. Mohamed Elloumi for his valuable suggestions and contributions to this dissertation.

My sincere thanks also go to the Platform for Agricultural Risk Management (PARM) - IFAD and in particular to Dr. Jesus Anton, who provided me an opportunity to join their team as an intern, and who gave access to various research facilities.

I am thankful for my colleagues Lorena Tudela-Marco, Emma Santarremigia, Paula Nieto and Maria Carmen Garcia Martinez for providing a friendly working atmosphere and always being ready to lend a hand when I need them.

I would also like to thank all the Dep. of Economics and Social Sciences team, which have always warmly welcomed me.

I am thankful to all my professors at the "Ecole Supérieur d'Agriculture de Mograne (ESAM)", the "Mediterranean Agronomic Institute of Zaragoza (IAMZ)" and the "Universitat Politècnica de Valencia (UPV)", for their support and the scientific formation during all my studies.

Finally, I am deeply and forever indebted to all my family for their tremendous love, continued support and encouragement throughout my entire life. Especially, my deepest thanks go to my husband "Bouali" for his patience and support in both the easy and hard times that I have faced. 


\begin{abstract}
The effect of Non-Tariff Measures (NTMs) on agri-food trade has drawn broad research interest and gained a substantial attention by scientific community as well as by policy makers. Sanitary and Phytosanitary (SPS) standards among others represent a major challenge for trade policy and food safety. The identification and measurement of the economic implications of NTMs require the use of an adequate both methodological and empirical framework to derive sound estimates. By targeting economic sectors and issues not previously investigated, this Thesis contributes to previous literature on determining the factors that affect the implementation of SPS and their effects on trade flows.
\end{abstract}

Four specific objectives have been pursued in four papers that constitute the main body of the present Thesis. The main purpose of the first paper is to investigate the scope of the reputation effect over time. To do so, we use The European Union (EU)'s Rapid Alert System for Food and Feed (RASFF) data on sanitary and phytosanitary notifications from 1998 to 2013. Two count data models have been implemented to estimate the distribution of current notifications. In line with previous literature, our findings indicate that reputation does affect current EU notifications. Furthermore, we identify some relevant exporter countries for which reputation is long-lasting.

The second paper aims at analyzing the behavior of the EU in controlling Aflatoxin (AF) contamination with respect to tree nuts and groundnuts for the period (1998-2015). To conduct this analysis, we have used a count data model, based on political economy considerations, past alerts and path dependence effects. Policy changes, including harmonization of AF standards and their further relaxing are estimated to have significant impact on the frequency of border controls.

In the third paper, we seek to assess the influencing factors on food standard enforcement in the EU with a special attention to agri-food imports from Mediterranean countries. We explore if there is any special treatment toward Mediterranean countries in controlling agri-food imports, testing if past border notifications affect current decisions on the implementation of food standards by the EU. RASFF notifications data over the period 2000-2012, and count data models are used for this purpose. Our empirical results support the hypothesis that previous food notifications may slightly affect current notifications; nevertheless, this effect seems to be less relevant for products of interest for Mediterranean 
Partner Countries. Hence, we cannot identify a pro or anti Mediterranean bias in the way that food safety controls are implemented at the EU borders.

The last paper focuses on the assessment of the competitiveness of the Tunisian agrifood sector before signing the Deep and Comprehensive Free Trade Agreement (DCFTA) with the EU. Specifically, competitive advantage measurement, based on the Tunisian National Institute of Statistics (INS) data over 2007-2012 period, has been used for this purpose. The analysis of the Tunisian agri-food sector reveals an important potential for exporting some agri-food staples. Recently, Tunisia is facing new challenges in exporting strategic products underlying the importance of adopting new business and marketing strategies or prospecting new markets. However, some agri-food subsectors, mainly animal products, milk and dairy products and cereals, remain unprepared to overcome the costs of the DCFTA due to their low competitiveness. Hence, Tunisian authorities could propose a progressive trade liberalization strategy with the EU. 


\section{Resumen}

El efecto de las medidas no arancelarias sobre el comercio agroalimentario ha generado un amplio interés en la investigación y ha recibido una atención considerable por parte de la comunidad científica y de los políticos de comercio. Las Medidas Sanitarias y Fitosanitarias (MSP), entre otras, representan un reto importante para la política comercial y la inocuidad de los alimentos. La identificación y medición de las implicaciones económicas de las MNT requieren el uso de un marco metodológico o empírico adecuado para derivar estimaciones sólidas. Al enfocarse en sectores económicos y temas no investigados previamente, esta tesis contribuye a la literatura previa sobre la determinación de los factores que afectan la implementación del MSP.

La tesis estudia cuatro cuestiones principales que se reflejan en cuatro artículos científicos independientes, que constituyen el elemento central de la misma. El principal objetivo del primer artículo es el de investigar el efecto reputación a lo largo del tiempo. Para ello, utilizamos los datos RASFF para el periodo 1998-2013. Se han implementado dos modelos de datos de recuento para estimar la distribución de las notificaciones actuales. De acuerdo con la literatura anterior, nuestras conclusiones indican que la reputación afecta a las notificaciones actuales de la UE. Además, identificamos algunos países exportadores relevantes cuya reputación es duradera.

El segundo artículo analiza el comportamiento de la UE en el control de la contaminación por Aflatoxina (AF) con respecto a los frutos secos entre el periodo 1998 y 2015. Para llevar a cabo este análisis, hemos utilizado un modelo de datos de recuento, basado en consideraciones de economía política, alertas pasadas y efectos de dependencia de trayectoria. Se estima que los cambios en las políticas, incluida la armonización de las normas AF y su posterior relajación, tienen un impacto significativo en la frecuencia de los controles en las fronteras.

En el tercer artículo, tratamos de evaluar los factores que influyen en la aplicación de normas alimentarias en la UE prestando especial atención a las importaciones agroalimentarias procedentes de países mediterráneos. Así, estudiamos si hay algún tratamiento especial hacia los países mediterráneos en el control de las importaciones agroalimentarias, contrastando si las notificaciones pasadas afectan las decisiones actuales sobre la aplicación de las normas alimentarias por parte de la UE. Los datos de las notificaciones RASFF durante el período 2000-2012 y los modelos de datos de recuento se 
utilizan para este fin. Nuestros resultados empíricos apoyan la hipótesis de que las notificaciones anteriores pueden afectar ligeramente a las notificaciones actuales. Sin embargo, este efecto parece ser menos relevante para los productos procedentes de los países mediterráneos. Por lo tanto, no podemos identificar un comportamiento pro o anti mediterráneo en la forma en que se implementan controles de seguridad alimentaria en las fronteras de la UE.

El último documento se centra en la evaluación de la competitividad del sector agroalimentario tunecino antes de firmar el Acuerdo de Libre Comercio Profundo y Amplio con la UE. Concretamente, se han utilizado indicadores de las ventajas competitivas, basándose en los datos del INS para el período 2007-2012. El análisis del sector agroalimentario tunecino revela un importante potencial de exportación de algunos productos básicos agroalimentarios. Recientemente, Túnez se enfrenta a nuevos retos en la exportación de productos estratégicos subrayando la importancia de adoptar nuevas estrategias comerciales y de comercialización o prospección de nuevos mercados. Sin embargo, algunos subsectores agroalimentarios, principalmente productos de origen animal, leche y productos lácteos y cereales, siguen sin estar preparados para soportar los costos del acuerdo de libre comercio profundo y completo debido a su baja competitividad. Por lo tanto, las autoridades tunecinas podrían proponer una estrategia progresiva de liberalización del comercio con la UE. 


\section{Resum}

L'efecte de les mesures no aranzelàries (MNT) sobre el comerç agroalimentari ha generat un ampli interés en la investigació $i$ ha rebut una atenció considerable per part de la comunitat científica i dels polítics de comerç. Les Mesures Sanitàries i Fitosanitàries (MSP), entre altres, representen un repte important per a la política comercial i la innocuïtat dels aliments. La identificació i mesurament de les implicacions econòmiques de les MNT requerixen l'ús d'un marc metodològic o empíric adequat per a derivar estimacions sòlides. A l'enfocar-se en sectors econòmics i temes no investigats prèviament, esta tesi contribuïx a la literatura prèvia sobre la determinació dels factors que afecten la implementació del MSF.

La tesi estudia quatre qüestions principals que es reflectixen en quatre articles científics independents, que constituïxen l'element central de la mateixa. El principal objectiu del primer article és el d'investigar l'efecte reputació al llarg del temps. Per a això, utilitzem les dades RASFF per al període 1998-2013. S'han implementat dos models de dades de recompte per a estimar la distribució de les notificacions actuals. D'acord amb la literatura anterior, les nostres conclusions indiquen que la reputació afecta les notificacions actuals de la UE. A més, identifiquem alguns països exportadors rellevants la reputació de les quals és duradora.

El segon article analitza el comportament de la UE en el control de la contaminació per Aflatoxina (AF) respecte a les fruites seques entre el període 1998 i 2015. Per a dur a terme esta anàlisi, hem utilitzat un model de dades de recompte, basat en consideracions d'economia política, alertes passades i efectes de dependència de trajectòria. S'estima que els canvis en les polítiques, inclosa l'harmonització de les normes AF i la seua posterior relaxació, tenen un impacte significatiu en la freqüència dels controls en les fronteres.

En el tercer article, tractem d'avaluar els factors que influïxen en l'aplicació de normes alimentàries en la UE, prestant especial atenció a les importacions agroalimentàries procedents de països mediterranis. Així, estudiem si hi ha algun tractament especial cap als països mediterranis en el control de les importacions agroalimentàries, contrastant si les notificacions passades afecten les decisions actuals sobre l'aplicació de les normes alimentàries per part de la UE. Les dades de les notificacions RASFF durant el període 20002012 i els models de dades de recompte s'utilitzen per a este fi. Els nostres resultats empírics recolzen la hipòtesi que les notificacions anteriors poden afectar lleugerament les notificacions actuals. No obstant això, este efecte pareix menys rellevant per als productes 
procedents dels països mediterranis. Per tant, no podem identificar un comportament pro o anti mediterrani en la forma en què s'implementen controls de seguretat alimentària en les fronteres de la UE.

L'últim document se centra en l'avaluació de la competitivitat del sector agroalimentari tunisenc abans de firmar l'Acord de Lliure Comerç Profund i Ampli amb la UE. Concretament, s'ha utilitzat indicadors dels avantatges competitius, basant-se en les dades de l'INS per al període 2007-2012. L'anàlisi del sector agroalimentari tunisenc revela un important potencial d'exportació d'alguns productes bàsics agroalimentaris. Recentment, Tunis s'enfronta a nous reptes en l'exportació de productes estratègics subratllant la importància d'adoptar noves estratègies comercials i de comercialització o prospecció de nous mercats. No obstant això, alguns subsectors agroalimentaris, principalment productes d'origen animal, llet i productes lactis i cereals, seguixen sense estar preparats per a suportar els costos de l'ALCD a causa de la seua baixa competitivitat. Per tant, les autoritats tunisenques podrien proposar una estratègia progres 


\section{Acronyms}

AA Association Agreements

ADF Augmented Dickey Fuller

AF $\quad$ Aflatoxin

AIC Akaike Information Criterion

DCFTA The Deep and Comprehensive Free Trade Area

EC European Commission

EFSA The European Food Safety Agency

ENPARD The European Neighborhood Program for Agriculture and Rural Development

EU European Union

Euro-Med Euro-Mediterranean

FAO Food and Agriculture Organization of the United Nations

GATT The General Agreement on Tariffs and Trade

GDP Gross Domestic Product

HS Harmonized System

INS The Tunisian National Institute of Statistics

JECFA The Joint FAO/WHO Expert Committee on Food Additives

MPCs $\quad$ Mediterranean Partner Countries

MRL Maximum Residue Level

MS Member States

MTND Millions of Tunisian Dinar

NB The Negative Binomial model

NTMs Non-Tariff Measures 
ppb Parts Per Billion

RASFF Rapid Alert System for Food and Feed

RCA Revealed Comparative Advantage

SMC South Mediterranean countries

SPS Sanitary and phytosanitary

TBT Technical Barriers to Trade

UMA The Arab Maghreb Union

UN The United Nations

UNCTAD The United Nations Conference on Trade and Development

US United States

WTO World Trade Organization

ZINB The Zero-Inflated Negative Binomial model 


\section{Table of contents}

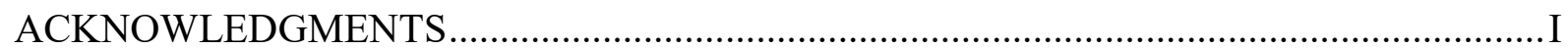

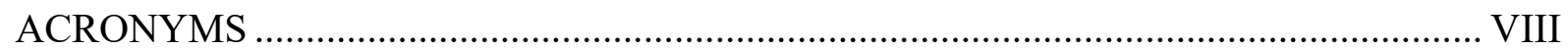

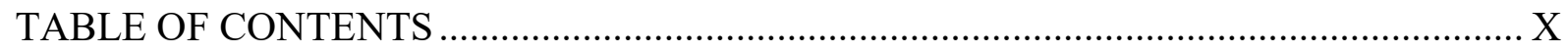

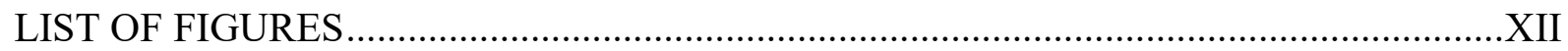

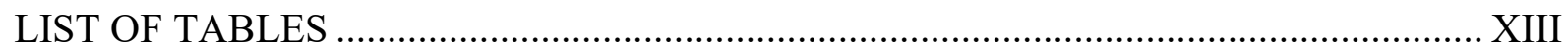

CHAPTER 1. INTRODUCTION AND OBJECTIVES …................................................ 1

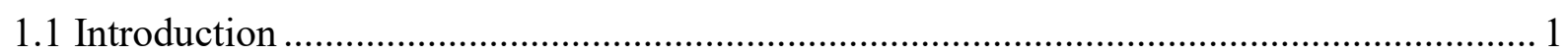

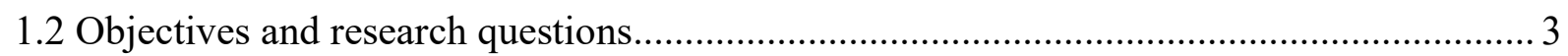

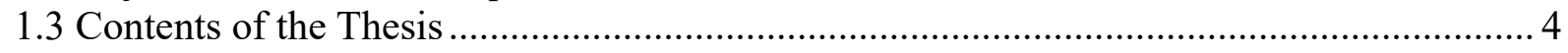

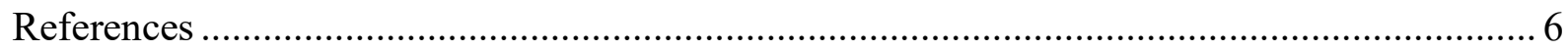

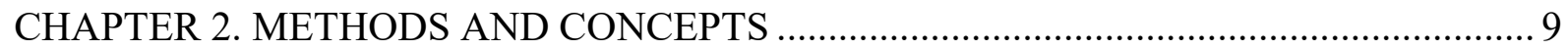

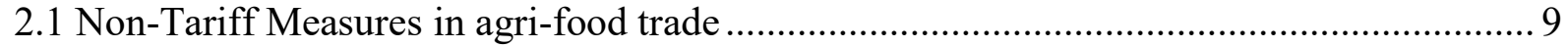

2.2. Euro-Mediterranean integration: Basic agreements on agri-food trade with the

Mediterranean Partner Countries ....................................................................................... 11

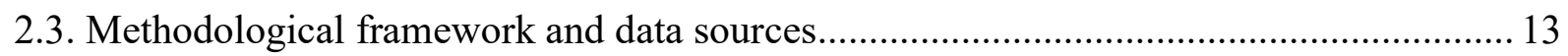

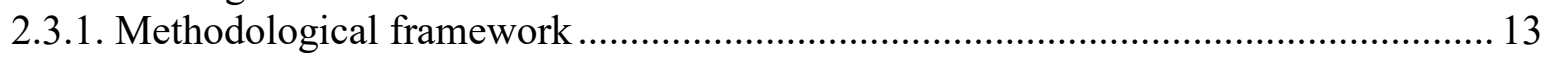

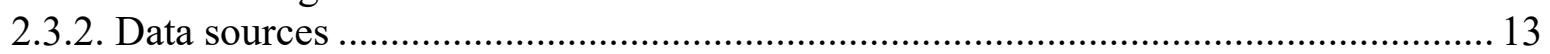

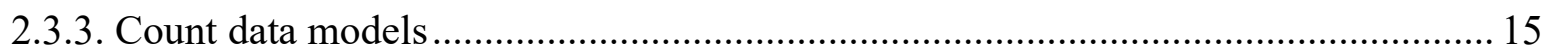

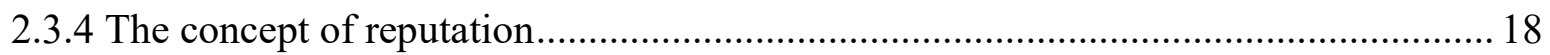

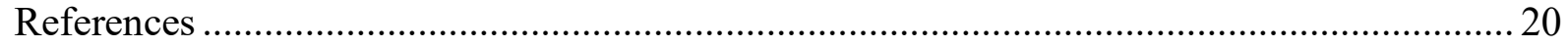

CHAPTER 3. SANITARY AND PHYTOSANITARY MEASURES IN AGRI-FOOD

IMPORTS FROM THE EUROPEAN UNION: REPUTATION EFFECTS OVER TIME... 26

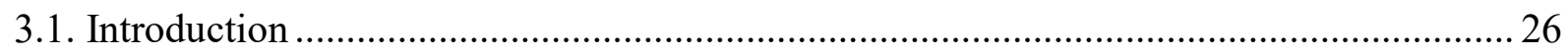

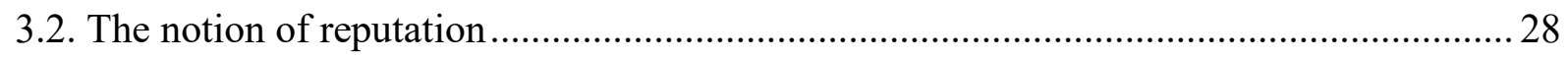

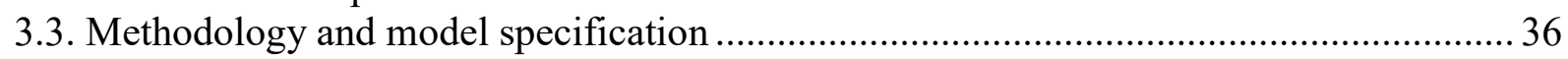

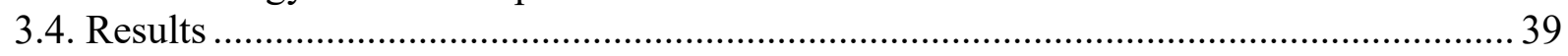

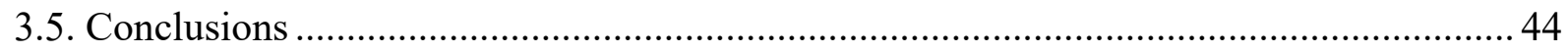

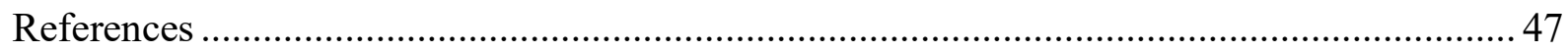

CHAPTER 4. IMPLICATIONS OF CHANGING AFLATOXIN STANDARDS FOR EU

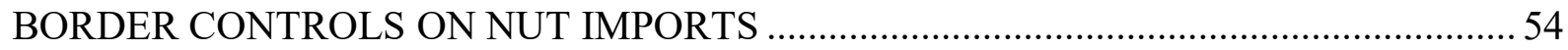

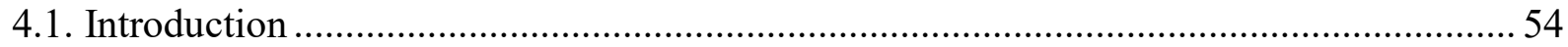

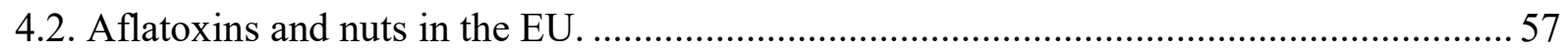

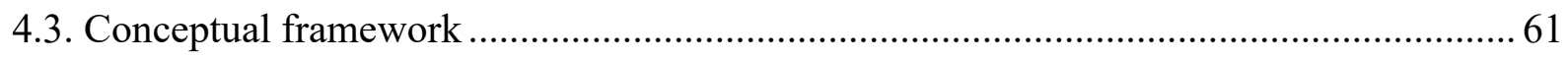

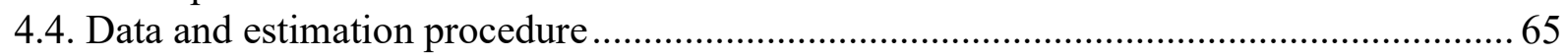

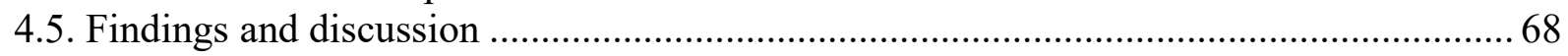

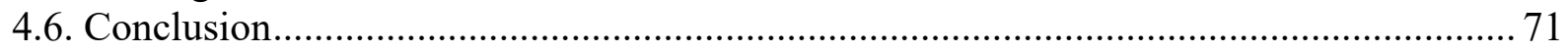

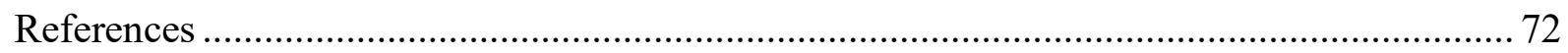

CHAPTER 5. EXPLORING EU FOOD SAFETY NOTIFICATIONS ON AGRO-FOOD IMPORTS: ARE MEDITERRANEAN PARTNER COUNTRIES DISCRIMINATED? ...... 80 


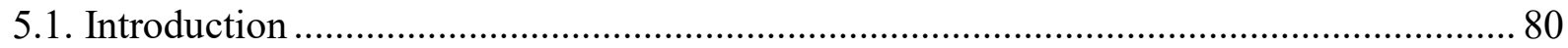

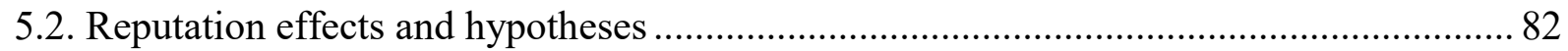

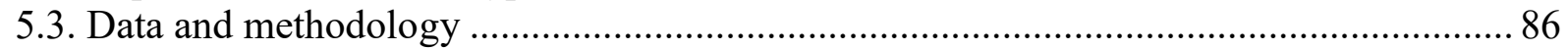

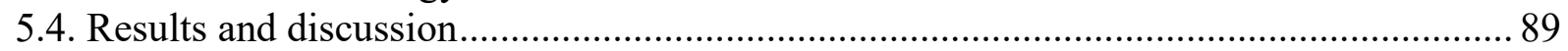

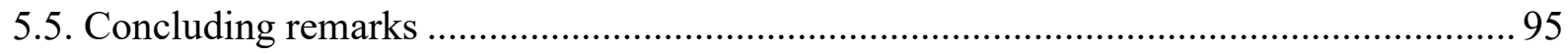

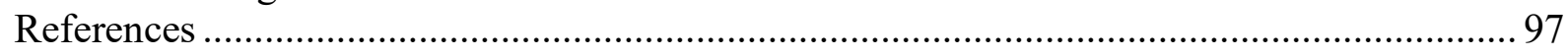

CHAPTER 6. FOOD SECURITY, COMPETITIVENESS AND TRADE: THE CASE OF

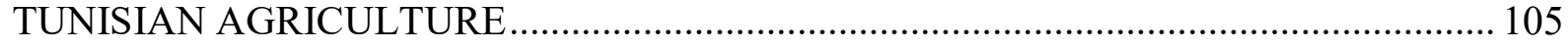

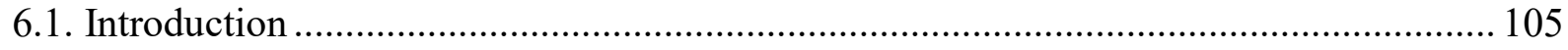

6.2. Agri-food sector, trade and DCFTA in Tunisia ........................................................... 107

6.3. Methodology: measuring the competitiveness of Tunisian agri-food products ............... 114

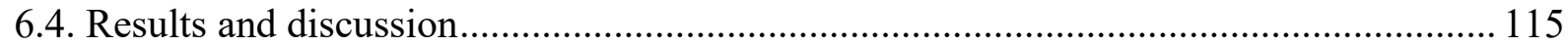

6.5. Conclusion and policy implications ……………………….................................... 117

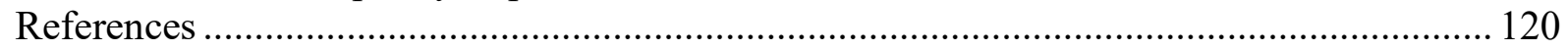

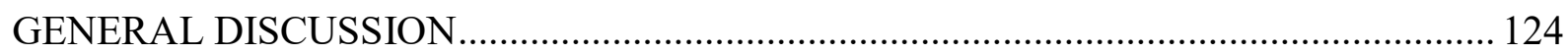

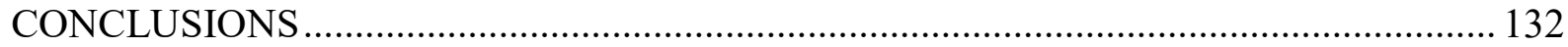

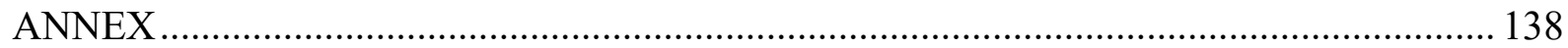




\section{List of figures}

Figure 1. Evolution in the number of notifications and breakdown by type (1998-2013)...... 32

Figure 2. Percent of total notifications by Member State (1998-2013) ................................. 33

Figure 3. Percent of total notifications by country, (average 1998-2013) .............................. 34

Figure 4. Percent of total notifications by Harmonized System 2 chapter, (average 1998-2013)

Figure 5. Comparison of the reputation effects between the top-ten notified countries and the

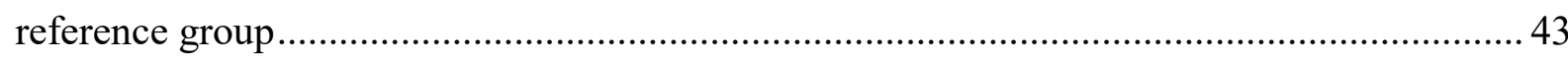

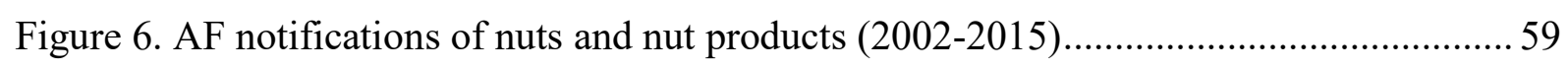

Figure 7. Percent of nuts and groundnut notifications by country , (average 1998-2015)....... 59

Figure 8. Main external suppliers of edible nuts of the EU in 2015 in thousands of euros ..... 60

Figure 9. Number of notifications applied by EU on agrifood Mediterranean exporters ........ 84

Figure 10. Product reputation. A correlation analysis of one-year lagged and current

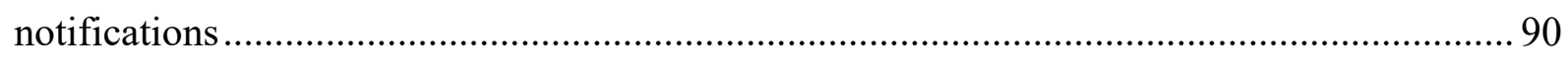

Figure 11. Relationship between the single average of notifications and their GDP per capita

Figure 12. Different counts of observed notification and those predicted by both models ..... 94

Figure 13. Agriculture value added share in Tunisia's GDP (1980-2014) ........................... 107

Figure 14. Evolution of Tunisian's Agri-food imports and exports (1993-2015) .................. 108

Figure 15. Evolution of Tunisia's agri-food imports and exports from the European Union

(2001-2014) 110 


\section{List of tables}

Table 1. Classification of Non-Tariff Measures by chapter............................................... 10

Table 2. Overview of discussed count regression models .................................................. 17

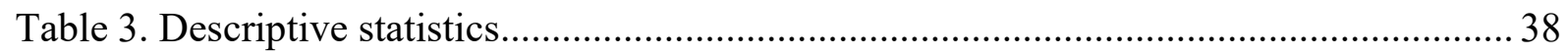

Table 4. Comparison between NB1 and ZINB1 estimations. Vuong test............................. 40

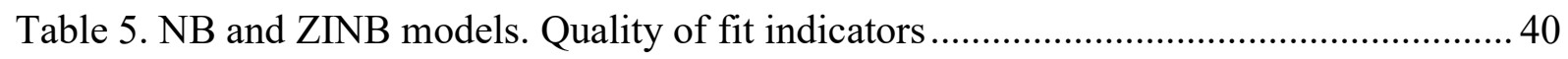

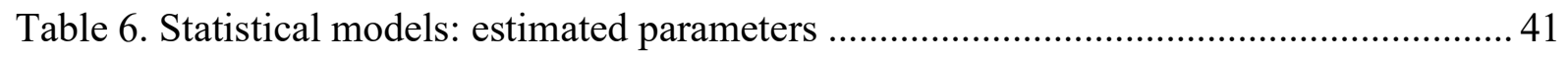

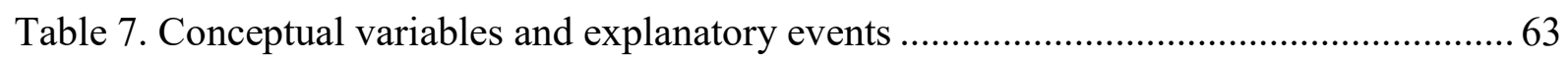

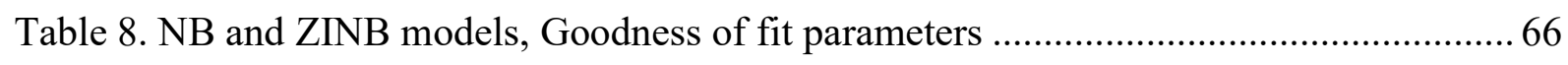

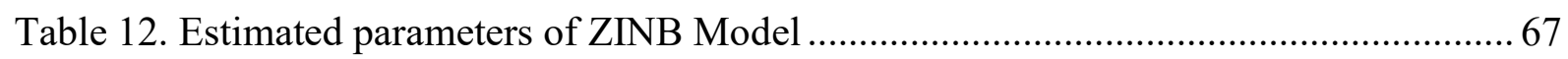

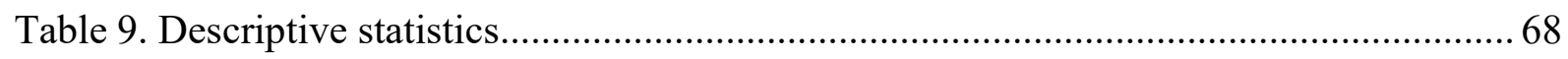

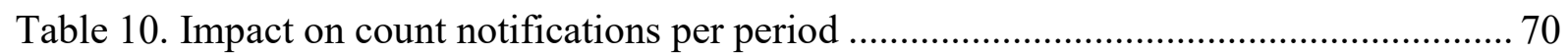

Table 11. Average notification count (2013-2015): No Codex scenario ................................ 71

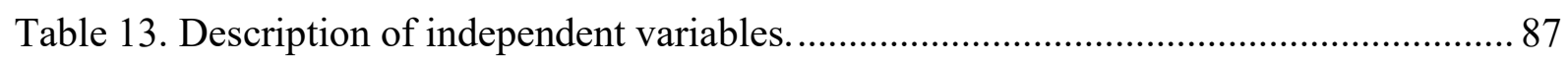

Table 14. Statistical models: estimated parameters and models' fit indicators ...................... 92

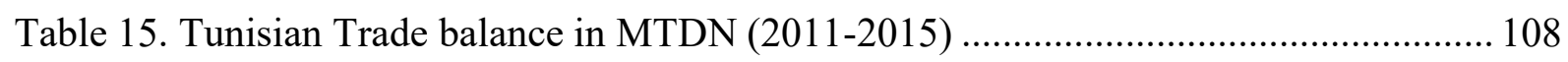

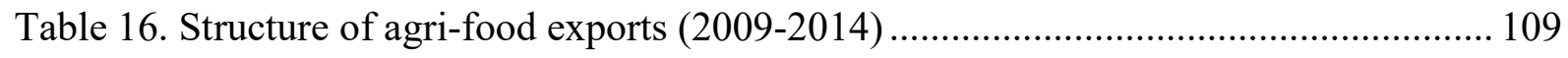

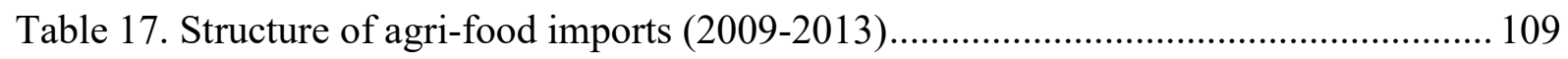

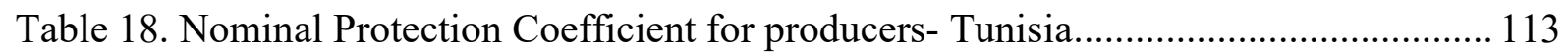

Table 19. RCA index of the Tunisian Agri-food products with the EU and UMA (\%) ........ 119 
Introduction and objectives 


\section{Chapter 1. Introduction and objectives}

\subsection{Introduction}

International agri-food trade has rapidly grown during the last decades. One of the most determinant factors of this expansion is the economic globalization. It significantly contributes to the integration of developing countries in the world markets. Agricultural trade policy is formed in a dynamic environment which has progressively incorporated new trade rules and negotiations.

Early agreements on agriculture began under the Uruguay Round of multilateral trade negotiations. The Uruguay Round Agreement represented an important first step toward the fundamental reform of the international trading system for agri-food commodities. Since then, negotiations and rules on agricultural trade have continuously been changed through multiple bilateral agreements to facilitate the developing countries access to developed country markets and make trade in agri-food products easier. This round led to conclude an agreement on Sanitary and Phytosanitary (SPS) measures providing a framework to implement, discuss and negotiate these standards. However, this reform may have "institutionalized" the production -and trade-distorting policies- of the developed countries and the fundamental concerns of developing countries have still to be addressed (Green and Priyadarshi, 2002). Under the reform process of agricultural trade policies (e.g. the long-lasting and not yet concluded Doha Round of multilateral trade negotiations, 1999-2001) there are discussions on issues such as the reduction of barriers to trade in agricultural and food products, including tariffs, quantitative restrictions and other trade measures.

Despite the progressive liberalization of world trade and the effort to reduce obstacles to trade through successive rounds of negotiations, concerns about the impact of other measures on agricultural and food exports have substantially increased since many of them are not explicitly trade-related (Henson and Loader, 2001). Non-Tariff Measures (NTMs) are becoming a potential challenge for developing countries' agricultural trade. These measures, known as technical or qualitative restrictions (e.g., food quality and SPS requirements), tend to prevent the development of agri-food exports by developing countries due to the lack of necessary resources and institutions to fulfill new and stricter standards set by developed countries (Petrey \& Johnson, 1993; Sykes, 1995; Thilmany \& Barrett, 1997). On one hand, NTMs have been used as frequent instruments that aim at the protection of food safety, human, plant and animal health, and the natural environment. On the other hand, the other 
side of these regulations may have a protectionist behavior which allows developed countries to effectively control their domestic markets and reduce imports (Yue \& Beghin, 2009; Nimenya et al., 2012; Disdier et al., 2015). According to Bacchetta \& Beverelli (2012), 94\% of specific trade concerns related to SPS measures overwhelmingly affects the agricultural sector. Thus, technical measures, including SPS and Technical Barriers to Trade (TBT), have significantly progressed in developed countries in general and in the European Union (EU) in particular. For instance, the number of notifications of technical measures has increased from 474 in 2000 to 2,583 in 2016 (RASFF, 2016). There is evidence that NTMs can have, either explicitly or implicitly an analogous effect as a barrier to trade like tariffs and quantitative restrictions (Vogel, 1995; Messerlin \& Zarrouk, 2000) that goes beyond the aforementioned protection of public goods.

Horton (1998) reported compliance with standards requirements is a necessary condition toward successful export trade especially in the case of agri-food commodities. The effect of standards has received an increasing attention of economists and policy makers to identify their implications on trade flows. NTMs are increasingly becoming an important determinant of agri-food trade and hence the international political concern about their implementation is on the rise (Disdier et al., 2008; Cadot et al., 2012).

The analysis of trade liberalization is an interesting area of research given the large number of countries that are involved in various preferential agreements. Several studies were devoted to analyze the agricultural trade liberalization in the Euro-Mediterranean region. The Euro-Mediterranean relations were led by a number of initiatives and programs to enhance trade. The EU is an attractive destination for the Mediterranean Partner Countries (MPCs) exports, given the relevant size and purchasing power of its agri-food demand, the geographical proximity and the importance of the historical trade relations. The implementation of NTMs on EU agri-food imports has been widely examined in previous literature. It has paid attention to Mediterranean exports to the EU by assessing the welfare effects of NTMs elimination (Kavallari et al., 2013) or the analysis of specific trade policy instruments (Garcia-Alvarez-Coque et al., (2009, 2010); Cioffi et al., 2011; Santeramo et al., 2014). Another line of research aimed to study the policy substitution between tariffs and NTMs in some MPCs (Tudela-Marco et al., 2014). As noted earlier, the notifications on SPS requirements have been rapidly increased. However, in recent years there have been a few attempts to study the factors that influence this trend of notifications. Indeed, it is of considerable interest to determine the possible rationale behind the food notifications, which 
can be the result of the management of specific risks and of the compliance level of the product or the country of origin.

Our work contributes to fill this gap in the literature on examining the past history compliance of product and country. Specifically, we attempt to identify the reputation effect in the case of EU agri-food imports by testing whether past notifications affect current notifications. More precisely, we want to ascertain, in the first place, whether this reputation exists or not and, if so, we aim to identify and address other questions that can help us gain an insight into the topic: Are there differences in the "trade effect" of reputation across countries? What are the influencing factors that determine the reputation of a given product, country, sector or region in agri-food trade? Does reputation evolve over time for a given country?

\subsection{Objectives and research questions}

The broad objective of the present dissertation is to analyze factors affecting the implementation of NTMs by the EU in importing agri-food products. In order to achieve this main objective, the specific objectives are the following:

- To analyze the behavior of the EU in controlling imported agri-food products.

- To examine NTM notifications by the EU to evaluate the compliance of developing economies with the EU standards, and understand the reasons why the number of notifications is increasing.

- To evaluate the impact of the reputation effects on EU import controls: reputation by product, sector, country and region.

Starting from these objectives we aim to explore the following research questions:

Q1. Reputation effects (or "path dependency") over time: What are the influencing factors that determine the reputation of a given product or county in agri-food trade? Does the past history compliance persist over time to influence the EU control in imports of agri-food staples?

Q2. Political and economic factors: In addition to history compliance, are there other factors such as political and economic considerations that could influence the EU controls for agrifood products affected by the aflatoxin hazard? (Case study of nut imports)

Q3. Limited capacities to comply with standards and controls have constrained the agri-food export of MPCs. Is there an anti or pro Mediterranean strategy in implementing EU's food 
safety policy? What are the influencing factors on food standard enforcement in the EU toward imports from the MPCs? (Case study of Mediterranean Countries)

Q4. Can trade agreements resolve the problem of market access to the MPCs? What are the expected outcomes from the Deep and Comprehensive Free Trade Area (DCFTAs) accruing to these countries? (Case study of Tunisia)

\subsection{Contents of the Thesis}

This Thesis employs count model estimation techniques to examine the determinant factors that influence notifications on agricultural and food products of developing countries to access markets in developed countries, particularly the EU, as well as competitiveness measures to assess the competitiveness of Tunisian agri-food products in respect to Europe and Maghreb before signing DCFTAs. Our scientific contribution is both methodological and of an empirical nature, and is organized in four main core chapters that constitute four independent published scientific papers. The analysis of the "reputation effect » which can affect agri-food trade is the guideline of this Thesis.

The first paper analyzes the scope of the reputation effect over time for the period 1998-2013. Further, this study contributes to the literature by extending the concept of reputation to allow for the dynamic effect of its pattern. To date, the impact of reputation has been checked only over a one-year period, and our starting research question is that this effect might be longer-lasting. So, we will check not only whether notifications in a given year affect notifications the following year, but we will also examine whether product reputation extends backwards in time up to the third preceding year.

The second research paper analyzes aflatoxin (AF) notifications of tree nuts, the most affected sector by this problem. For it, we analyze imports from 65 countries during the period 1998-2015. The revision of AF standards has involved changes in controls and in border refusals as measured by notifications at the Rapid Alert System for Food and Feed (RASFF). A count data model tested the determinants of border controls on EU imports of these products, based on political economy considerations, past alerts and path dependence effects.

The third paper seeks to assess the influencing factors on food standard enforcement in the EU with a special attention to agri-food imports from MPCs. We explore if there is any special treatment toward MPCs in controlling agri-food imports, testing if past border notifications affect current notifications. In other words, if past notifications affect current 
decisions on the implementation of food standards by the EU. Methodologically, notifications are extracted from those reported on the RASFF over the period 2000-2012, and count data models are used to account for the over-dispersion existing in them.

The last paper has the form of a book chapter. It pays attention to assess the competitiveness of Tunisian agri-food products in respect to Europe and Maghreb before signing DCFTAs. In addition, it aims at identifying and assessing the main points of controversy related to the DCFTAs between the EU and Tunisia and the ways to mitigate them from the Tunisian point of view, by exploring some of the issues related to the rural communities and market actors in Tunisia.

In addition to this general introduction, the used methods and concepts and the concluding remarks section, the present Thesis is organized into four chapters containing the four papers summarized above. The first paper (chapter 3) entitled "Sanitary and Phytosanitary measures in agri-food imports from the European Union: Reputation effects over time", has been published in the journal "Economia Agraria y Recursos Naturales". The second paper (chapter 4) is entitled "Implications of changing aflatoxin standards for EU border controls on nut imports", will be presented in the XV congress of the European Association of Agriculture Economists 2017. The third paper (chapter 5), entitled "Exploring EU food safety notifications on agro-food imports: Are Mediterranean Partner Countries discriminated?" has been published in the International Journal of Food and Agricultural Economics. The last paper (chapter 6) entitled "Food security, competitiveness and trade: The case of Tunisian agriculture", has been already published as a book chapter in the book "Food Security and Sustainability"1. These chapters will be followed by a general discussion and conclusions to synthesize the main findings achieved in the four previous chapters. Based on these results, some policy implications as well as recommendations for future studies are derived. Then the dissertation finishes with some concluding remarks.

\footnotetext{
${ }^{1}$ Mergos, G. and Papanastassiou, M. (2017). Food Security and Sustainability. Cham: Springer International Publishing.
} 


\section{References}

Bacchetta, M., \& Beverelli, C. (2012). Trade and public policies: A closer look at non-tariff measures in the 21st century. International Trade Forum, 3(19), International Trade Center.

Cadot, O., Malouche, M. \& Sáez, S. (2012). Streamlining Non-Tariff Measures: A Toolkit for Policy Makers. World Bank Publications.

Cioffi, A., Santeramo, F. G., \& Vitale, C. D. (2011). The price stabilization effects of the EU entry price scheme for fruit and vegetables. Agricultural Economics, 42(3), 405-418.

Disdier, A. C., Fontagné, L., \& Cadot, O. (2015). North-South standards harmonization and international trade. The World Bank Economic Review, 29(2), 327-352.

Disdier, A. C., Fontagné, L., \& Mimouni, M. (2008). The impact of regulations on agricultural trade: evidence from the SPS and TBT agreements. American Journal of Agricultural Economics, 90(2), 336-350.

Garcia-Alvarez-Coque, J. M., Martinez-Gomez, V., \& Villanueva, M. (2009). A trade model to evaluate the impact of trade liberalisation on $\mathrm{EU}$ [European Union] tomato imports. Spanish Journal of Agricultural Research, 7(2), 235-247.

Garcia-Alvarez-Coque, J. M., Martinez-Gomez, V., \& Villanueva, M. (2010). Seasonal protection of F\&V imports in the EU: impacts of the entry price system. Agricultural Economics, 41(2), 205-218.

Green, D., \& Priyadarshi, S. (2001). Proposal for a 'Development Box'. The WTO Agreement on Agriculture. FAO Geneva Round Table on Special and Differential Treatment in the Context of the WTO Negotiations on Agriculture, 1.

Henson, S., \& Loader, R. (2001). Barriers to agricultural exports from developing countries: The role of sanitary and phytosanitary requirements. World development, 29(1), 85102.

Horton, L. R. (1998). Food from developing countries: steps to improve compliance. Food and Drug Law Journal, 53, 139.

Kavallari, A., Rau, M. L., \& Rutten, M. (2013). Economic Growth in the Euro-Med Area through Trade Integration: Focus on Agriculture and Food Regional impact analysis. Joint Research Center Scientific and Policy Report.

Messerlin, P. A., \& Zarrouk, J. (2000). Trade Facilitation: Technical regulations and customs procedures. The World Economy, 23(4), 577-593. 
Chapter 1. Introduction and objectives

Nimenya, N., Ndimira, P. F., \& de Frahan, B. H. (2012). Tariff equivalents of non tariff measures: The case of European horticultural and fish imports from African countries. Agricultural Economics, 43(6), 635-653.

Petrey, L. A., \& Johnson, R. W. M. (1993). Agriculture in the Uruguay round: sanitary and phytosanitary measures. Review of Marketing and Agricultural Economics, 61(3), 433 442.

Santeramo, F. G., Capitanio, F., \& Adinolfi, F. (2014). Integrating agricultural risks management strategies in selected EU Partner Countries: Syria, Tunisia, Turkey. Romanian Journal of European Affairs, 14, 22.

Thilmany, D. D., \& Barrett, C. B. (1997). Regulatory barriers in an integrating world food market. Review of Agricultural Economics, 91-107.

Tudela-Marco, L., Garcia-Alvarez-Coque, J. M., \& Martinez-Gomez, V. (2014). Are nontariff measures a substitute for tariffs in agricultural trade? Recent evidence from southern Mediterranean countries. Outlook on Agriculture, 43(4), 235-240.

Vogel, D. (2009). Trading up: Consumer and environmental regulation in a global economy. Cambridge, MA: Harvard University Press.

Yue, C., \& Beghin, J. C. (2009). Tariff equivalent and forgone trade effects of prohibitive technical barriers to trade. American Journal of Agricultural Economics, 91(4), 930941. 
Methods and concepts 


\section{Chapter 2. Methods and concepts}

The economics of regulatory barriers to international agri-food trade has gained relevant attention during the last decades. NTMs are one of the main reasons that may increase trade costs. However, their impacts are still poorly understood and not easily assessed given the frequency and the complexity of these measures and the challenge they present for future trade pattern (Ndaysienga and Kinsey, 1994; Sykes, 1995; Gourdon, 2014). A better understanding of NTMs would be helpful for policymakers who are interested in establishing more efficient trade policy decisions. These decisions can improve the performance of international trade as well as promote economic development. In the following sections, a description of the methods and concepts relative to NTMs is presented.

\subsection{Non-Tariff Measures in agri-food trade}

\subsubsection{NTMs definition and classification}

Broadly defined, NTMs include all measures distorting the conditions of international trade, hence affecting prices and quantities traded. They encompass policies and regulations that restrict trade and those that facilitate it. The most commonly used definition was introduced by the United Nations Conference on Trade and Development (UNCTAD) $(2010,16)$ "NTMs are policy measures, other than ordinary customs tariffs, that can potentially have an economic effect on international trade in goods, changing quantities traded, or prices or both". For practical purposes, NTMs were aggregated into various "chapters" based on the UNCTAD classification (WTO, 2012): Each "chapter" is differentiated into several subgroups to include measures with similar purposes and belonging to the same scope. This breakdown consists of 16 chapters (A to P) classified into two main categories to facilitate the data assembling and collection (table 1):

- Technical measures: include SPS, TBT and other border requirements. They are the chapters A-C in the UNCTAD classification.

- Non-Technical measures: group hard measures such as price and quantity control measures, threat measures (antidumping and safeguards) and other measures such as trade related finance and investment measures. Chapters D-O in the UNCTAD classification.

- Export-related measures that are classified under the P chapter. 
Table 1. Classification of Non-Tariff Measures by chapter

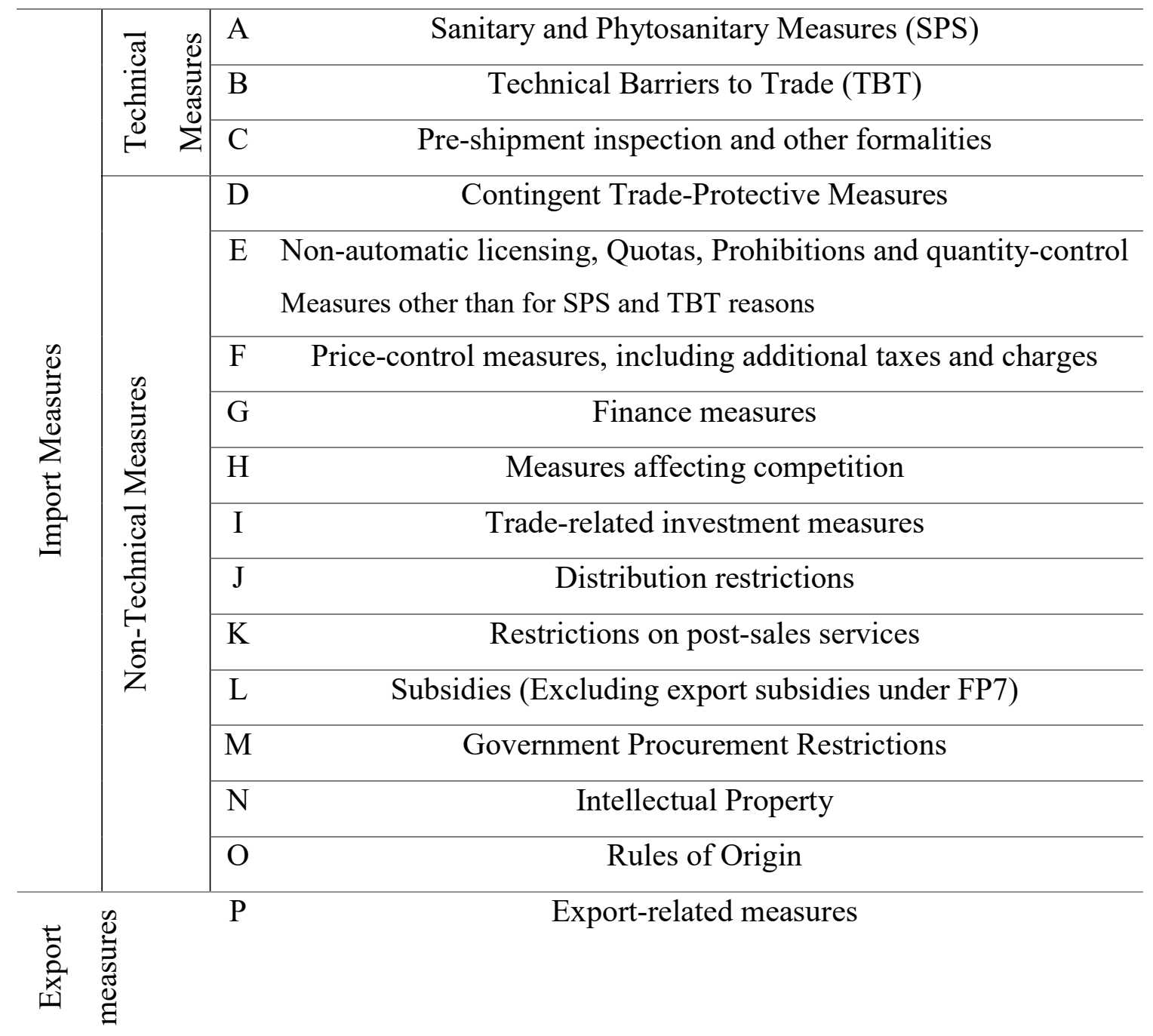

Source: UNCTAD secretariat, 2015

The incidence of NTMs varies across countries and products. The SPS and TBT are the most employed forms of NTMs especially in case of agri-food products and present many concerns for exporting countries. SPS standards aim to insure a certain level of food safety for consumers and to protect the human, animal and plant health. Besides, all quality aspects related with the production process (organic, fair trade) are considered as SPS measures. However, TBT standards encompass related standards with the physical attributes of products such as the labelling and marketing standards (size, quality classes).

There are various reasons to focus attention on NTMs as an important source of trade costs. The analysis of NTMs is still considered a difficult and challenging task due to the lack of detailed information on these measures across countries and products. NTMs are possibly 
used to address market failures, to ensure high quality and compliance with technical standards (Mahé et al., 1997; Disdier et al., 2015), but also for protectionist purposes (Yue \& Beghin, 2009; Nimenya et al., 2012). Another line of discussion refers to the political economy behind the implementation of NTMs in different countries.

A relevant issue for both researchers and policymakers is regarding the impact of NTMs on trade. The number of studies that focus on investigating the trade effect of NTMs on agri-food trade is significantly increasing (Yue and Beghin, 2009; Cadot et al., 2012). However, there is a shortage of studies dealing with NTMs trade impact by product or country, even existing studies tend to be rather scarce and inconclusive. Indeed, De Frahan and Vancauteren (2006) suggest that NTMs have a positive and significant impact on intraEurope trade (except for condiments) after the harmonization of standards. The analysis of NTMs effects on agri-food trade represents the mainstream of the literature using frequently gravity models (Otsuki et al., 2001; Wilson and Otsuki, 2004; Anders and Caswell, 2009).

\subsection{Euro-Mediterranean integration: Basic agreements on agri- food trade with the Mediterranean Partner Countries}

In the current stage of Euro-Mediterranean integration, its main objective is to create a free trade area which aims to remove trade barriers and enhance investment between the EU and the MPCs. This is consistent with the past stages, as the Euro-Mediterranean relations were guided by a number of initiatives and programs to boost trade. The analysis of trade liberalization is an interesting area of research given the large number of countries that are involved in Euro-Mediterranean trade agreements and preferential programs. In addition, the EU is an attractive destination for the MPCs' exports, given the relevant size of its agri-food market, the geographical proximity and the importance of the historical trade relations. Not surprisingly, the EU is the main trade partner for most Mediterranean countries.

The Barcelona Process or Euro-Med partnership was launched in 1995 with the participation of $15 \mathrm{EU}$ Member States (MS) at that time and 12 Mediterranean non-member countries (Algeria, Cyprus, Egypt, Israel, Jordan, Lebanon, Malta, Morocco, Syria, Palestine, Tunisia and Turkey). This conference aimed at the creation of free trade area to share prosperity in the Mediterranean region. Then, a number of Association Agreements (AA) have been signed since the beginning of the process. They are steps to enhance the EuroMediterranean cooperation and to move from shallow to deep integration with standards and regulatory framework harmonization. 
Almost all MPCs concluded the AA with the EU. ${ }^{2}$ Tunisia was the first country that signed an AA with the EU in 1995. Negotiations keep advancing to ensure trade liberalization of agri-food products with other MPCs. Accordingly, the Agadir agreement was established to reinforce trade liberalization in agri-food products between some Arabic Mediterranean countries (Jordan, Egypt, Morocco and Tunisia). It was signed in 2004 and entered into effect in 2006 to create a free trade area between the abovementioned countries. In line with the Barcelona Process, the objectives of this agreement support the harmonization of the economic legislations, the private and public economic policies with the European MS especially in areas of international trade and agriculture.

Ten years after the launch of the Barcelona Process, the objective of creating a Free Trade Area by 2010 was reaffirmed. The partners insisted on the fact that achieving this objective would allow reshaping the Mediterranean strategy for sustainable development through reviewing the implementation of all relevant regional agreements. Besides, the nontariff aspects of agricultural trade liberalization were discussed to take into account the characteristics of the agricultural sector in each country.

Furthermore, two European initiatives have been launched to support MPCs: the European Neighborhood Program for Agriculture and Rural Development (ENPARD), running from 2014 to 2020, and the Deep and Comprehensive Free Trade Agreements (DCFTA) which are under discussion. Hence, the EU attempts to re-define a new Mediterranean policy to deal with existing social and trade issues.

In the beginning, the DCFTA was an initiative to create a free trade area with Georgia, Moldova and Ukraine. In 2011, preparation sessions for negotiations were begun to implement DCFTAs with different Mediterranean Countries (Egypt, Jordan, Morocco and Tunisia). The DCFTA guarantees the access of associated countries to the EU domestic market in selected sectors. Besides, this agreement aims to ensure to the European investors the same regulatory environment in the MPCs.

In the Mediterranean area, negotiations about trade liberalization of agriculture and processed food remain open and controversial. Besides, the indicators of openness vary across

\footnotetext{
${ }^{2}$ Chronological order of Signing the Association Agreement by partner: Tunisia (1995), Israel (1995), Morocco (1996), Palestinian authorities (1997), Jordan (1997), Egypt (2001), Algeria (2002), Lebanon (2002).
} 
MPCs given the heterogeneity of macroeconomic performance. In the current Thesis, the case of Tunisia has been selected to investigate about the effects of further trade liberalization. Tunisia has concluded a number of agreements in agri-food trade. Among them, current negotiations on the liberalization of trade in agriculture will be integrated in the framework of the DCFTA. In this country, agriculture is a relevant economic and social sector with national priority. Nowadays, the EU is the main destination of Tunisian agri-food products and only the agricultural sector is expected to benefit from this agreement (Ecorys, 2013).

\subsection{Methodological framework and data sources}

The present research proposes an analysis of the determinant factors in implementing NTMs applied by the EU. Indeed, two complementary approaches have been developed: The first one deals with whether the application of food notifications is guided by economic and political considerations. The second one aims at assessing whether the implementation of NTMs varies among exporting countries or imported products.

The first approach addresses the first and second research questions (Q1 and Q2), while the second approach focuses on related issues with trade with MPCs based on the third and fourth research questions (Q3 and Q4). After reviewing the methodologies employed to deal with them, the research questions are investigated separately based on different empirical methodologies.

\subsubsection{Methodological framework}

This research proposes an analysis of the European application of NTMs at different levels: the product, the sector, the exporter and the region. The first step of analysis focuses on a number of political and economic factors that could explain the implementation of NTMs in importing agri-food products. The second level extends the analysis to deal with a specific region (the MPCs) and then deals with a specific product (nuts and peanuts). The third level considers the implication of applying a free trade agreement on agri-food export of a selected country (the case of Tunisia). The following lines offer a description of the methodology used to achieve the aforementioned objectives.

\subsubsection{Data sources}

For this Thesis, the main source regarding the notifications issued at the EU borders is the RASSF. It is a searchable online database of notifications. This portal is constructed to provide the control authorities of food and feed with an effective tool for exchange of 
information on measures adopted to warrant food safety. More specifically this tool allows responding rapidly to serious dangers detected with respect to food or feed. The exchange of data is of a great importance for MS to act faster and in an organized manner against any health risk detected in one or more consignments of a food or feed.

RASFF notifications usually account about risks identified in food, feed or food contact materials that are placed on the market in the notifying country or detained at an EU point of entry at the border with an EU neighboring country (EC, No 16/2011). According to this regulation, the notifying country has to report on the risks it has detected, the product and its traceability and the measure it has taken.

Depending on the seriousness of the identified risks and the distribution of the product on the market, the RASFF notification can be classified after check by the Commission contact point as alert, information or border rejection notification. The identification procedure precedes the transmitting of any type of notification to all network members. Following the aforementioned regulation, these types of notifications can be defined as follows:

- Alert notifications: An 'alert notification' or 'alert' is identified when a food, feed or food contact material presenting a serious risk on the market. The detected product needs a rapid action in another country than the notifying country. Alerts are sent by the Member State that detects the problem and has initiated a relevant measure, such as withdrawal or recall. This type of notification attempts to give all the members of the network the information to check whether the concerned product is on their market, so that they can take the necessary measures.

- Information notifications: An 'information notification' refers to food, feed or food contact material for which a risk has been identified. This type of notification does not require quick action either because the risk is not perceived dangerous or the product is not on the market at the time of notification.

- Border rejection notifications: this type of notification concerns a consignment of food, feed or food contact material that was refused access to the European Union for reason of a risk to human health and also to animal health or to the environment if it concerns feed.

It is worth noting that the RASFF portal provides a complete database with product information in verbal form, but notifications are not classified under the Harmonized System. The number of notifications can be taken as a direct measure of NTMs. Indeed, the RASFF has been used previously to analyze the impact of SPS measures of the EU trade (Jaud et al, 
2013; Kallummal et al, 2013; Kleter et al, 2009). Three original databases were built from the RASFF text information system by counting food notification.

The first dataset has been used in chapter 3, for the period 1998-2013, to analyze the effect of sanitary and phytosanitary measures in agri-food imports from the EU over time. This dataset covers HS chapter 4 of all agri-food products from the top 39 most notified countries in the period under consideration. These countries' export received 15,098 notifications which account for $34 \%$ of total notifications in the mentioned period.

The second dataset that has been used in chapter 4 includes all aflatoxins notifications of nuts and peanuts. All notifications were coded into HS 6 digits to insure the identification of notified product. Other explicative variables were included in the dataset referring to some economic and political considerations: the import value of each notified product, the per capita GDP of exporting county and the number of published scientific articles.

The third dataset has been prepared including notifications registered by the EU on shipments from 21 countries in the last years (2000-2012); the latter are selected to cover a wide range of geographical origins, by taking top developing countries ranked according their weight in total exports to the EU. The selection started with a larger list of countries though we finally took only those who have a significant number of notifications according to RASFF. Apart from the selected top exports a series of countries from the Southern and Eastern Mediterranean region was considered in order to assess the impact of NTMs on the agri-food trade from MPCs. Thus, eight MPCs, namely Algeria, Egypt, Israel, Jordan, Lebanon, Morocco, Syria, Tunisia and Turkey, are included in the sample.

The last paper includes data from the Tunisian national portal of statistics to analyze the competitiveness of Tunisian agri-food products. The data is used to estimate the revealed comparative advantage index of Tunisian agri-food exports with respect to the European Union and the Arab Maghreb.

\subsubsection{Count data models}

Once the three datasets extracted from the RASFF portal are built, the statistical treatment is carried out through count data models. Count data is a statistical data type in which all observations are non-negative integers representing the number of occurrences of an event within a fixed period.

The scope of count data models is very large. Modeling count data is a common task in economics and the social sciences. The statistical treatment of count data is distinct from that of binary and ordinal data. With regard to estimation of the models fitting to the datasets 
built, we faced two main challenges. The data were overdispersed with a high presence of zeros which could have qualitative consequences of the estimated model. The problem of overdispersion occurs when the observed variability exceeds the expected variability. Undetected overdispersion may cause important misleading inferences: First, the standard errors obtained from the model will be incorrect and may be underestimated (Ridout et al., 1998). Therefore, the significance of individual regression parameters will be incorrectly interpreted. Second, changes in deviance connected with model terms will also be too large and this will lead to choose an over complex model. An important task in this Thesis is choosing a parametric model to fit a given set of empirical observations. This step necessitates an evaluation of the fit of the chosen model.

The classical model for count data is the Poisson regression model, which is a special case of the Generalized Linear Model. This model is resulted from the Poisson distribution and deals with count data in many fields such as insurance number of insurance claims (Heller et al., 2007), public health -as the number of doctor visits or epidemiology (Winkelmann, 2004). This model is often of limited use on these disciplines due to particularities of empirical count data sets (overdispersion or an excess of zeros). The problem of overdispersion can be corrected by estimating an additional dispersion parameter to obtain the so-called quasi-Poisson model. To deal with this issue, the negative binomial regression has been proposed as an appropriate tool. The negative binomial is an alternative approach to modeling overdispersion in count data by adding a multiactive random effect to show the unobserved heterogeneity. All of these models are classified under the family of generalized linear models (McCullagh and Nelder, 1989). Typically, these models can resolve the problem of overdispersion but they are not sufficient to estimate data with excess zeros.

Since Mullahy (1986) and Lambert (1992), there is an increasing interest in zeroaugmented models that capture the excess number of zeros. To do so, a second model component was added to capture zero counts. We distinguish zero inflated models introduced by Mullahy (1986) which associate a left truncated count component with a right-censored hurdle component. There are two origins of zeros: zeros sourced from both the point mass and from the count component. Besides, the zero-inflated models are presented by different approaches and considered as mixture models by integrating a count component and a point mass at zero. A complete overview of count data models is provided by Cameron and Trivedi $(1998,2005)$. The probability density function of discussed models above is presented in table 2. 
Chapter 2. Methods and concepts

Table 2. Overview of discussed count regression models

\begin{tabular}{|c|c|}
\hline Model & The probability density function \\
\hline $\begin{array}{l}\text { Generalized } \\
\text { Linear Model }\end{array}$ & $\begin{array}{l}\qquad f(y ; \lambda, \Phi)=\exp \left(\frac{y * \lambda-b(\lambda)}{\Phi}+c(y, \Phi)\right) \\
y_{i}(\mathrm{i}=1, \ldots, \mathrm{n}): \text { a vector of regressors } x_{i} \\
\lambda: \text { the canonical parameter } \\
\Phi: \text { a dispersion parameter } \\
\mathrm{b}(.), \mathrm{c}(.) \text { : determine which member of the family is used (the normal, } \\
\text { binomial or Poisson distribution) }\end{array}$ \\
\hline Poisson & $\begin{array}{l}\qquad f(y ; \mu)=\frac{\exp (-\mu) * \mu^{y}}{y !} \\
g(\mu)=\log (\mu): \text { the canonical link }{ }^{3} \\
\text { The dispersion parameter is fixed at } \\
\Phi=1\end{array}$ \\
\hline Negative & $\begin{array}{l}\qquad f(y ; \mu ; \theta)=\frac{\Gamma(y+\theta)}{\Gamma(\theta) * y !} * \frac{\mu^{y} * \theta^{\theta}}{(\mu+\theta)^{y+\theta}} \\
\theta \text { : the shape parameter } \\
\Gamma() \text { : the gamma function } \\
\text { The dispersion parameter is fixed at } \\
\Phi=1\end{array}$ \\
\hline $\begin{array}{l}\text { Zero Inflated } \\
\text { Negative } \\
\text { Binomial }\end{array}$ & $\begin{array}{l}\text { This model is a mixture of a point mass at zero } I_{\{0\}} \text { and a count distribution } \\
f_{\text {count }}(y ; x ; \beta) \text {. The probability of observing a zero count is inflated with } \\
\text { probability } \pi=f_{\text {zero }}(0 ; z ; \gamma) \text { : } \\
f_{\text {soroinfl }}\left(y ; x_{1} z_{1}, \beta, y\right)=f_{\text {aore }}(0 ; z, y) * I_{[0\}}(y)+\left(1-f_{\text {sore }}(0 ; z, y)\right) * f_{\text {oount }}\left(y ; x_{1}, \beta\right)\end{array}$ \\
\hline
\end{tabular}

\footnotetext{
${ }^{3}$ The canonical link mentioned in the table is resulting in a log-linear relationship between mean and linear predictor
} 


\begin{tabular}{|l|l|}
$\mathrm{I}():$. the indicator function \\
$\pi:$ the unobserved probability of belonging to the point mass component \\
modeled by Generalized Linear Model $\pi=y^{-1}\left(z^{T} \gamma\right)$ \\
$z_{i}:$ the vector of regressors in the zero-inflation model \\
$x_{i}:$ the regressors in the count component
\end{tabular}

Source: Authors' elaboration based on Zeiles et al (2008).

\subsubsection{The concept of reputation}

The main contribution of the present Thesis is to evaluate the impact of NTMs on agri-food trade by examining the concept of reputation. This conceptual contribution is considered as a new line of research to be developed and extended using the mentioned econometric models.

First, we investigate the concept of reputation. It refers to the role of extra-EU exporters on the decision of the EU as importer to release a notification with an existing buyer-seller partnership. Depending on the foreign products compliance in previous years, the importer will have a belief or an intuition that affects their decisions of import in the following year. By exploring the RASFF notifications, various products seem to be more sensitive than others and receive high number of notifications. The notion also includes sectors, countries and regions that are exposed to a higher likelihood of being more and more notified by the importer (the EU).

Occurrence of repeated notifications could affect directly the exporting countries and may lead to additional costs. Indeed, testing the compliance of a product with the EU standards and the time needed to achieve the verification may involve costs for the exporter. The rise of costs and the border rejection of certain products will make the country reputation at risk.

There are some products deemed to be sensitive in terms of food safety more than others. The seafood, nuts and vegetables are the most notified products compared to other exported agri-food products. This relies upon the high number of notifications founded in the RASFF portal. Nevertheless, we want to test if the European control penalizes those products already affected by notifications released in previous periods. This analysis further assesses to what extent this control can affect developing country exports.

To do so, we will examine in this dissertation four types of reputation: 
Chapter 2. Methods and concepts

Product reputation means the presence of a correlation between the number of notifications for a given product-country-year combination and the number of notifications affecting that product-country combination in the previous year.

Sector reputation refers to a relationship between the number of notifications affecting a given product-country-year combination and the number of notifications affecting related products (those in the same HS2 chapter) -country combination in the previous year.

Country reputation is defined as the correlation between the number of notifications affecting a given product-country-year combination and the total number of notifications affecting that products-country combination in the previous year.

$\underline{\text { Region reputation }}$ can be determined through the presence of an association between the number of notifications affecting a given product-country-year combination and the total number of notifications affecting all products- 'region countries' combination in the previous year. 
Chapter 2. Methods and concepts

\section{References}

Anders, S. M., \& Caswell, J. A. (2009). Standards as barriers versus standards as catalysts: Assessing the impact of HACCP implementation on US seafood imports. American Journal of Agricultural Economics, 91(2), 310-321.

Cameron, A. C., \& Trivedi, P. K. (2005). Microeconometrics: methods and applications. Cambridge university press.

Cameron, A.C., \& Trivedi, P. K. (1998). Regression analysis of count data. Econometric society monographs, 30 .

De Frahan, B. H., \& Vancauteren, M. (2006). Harmonisation of food regulations and trade in the Single Market: evidence from disaggregated data. European Review of Agricultural Economics, 33(3), 337-360.

Ecorys, (2013). Trade sustainability Impact Assessment in Support of Negotiations of a DCFTA between the EU and Tunisia. Rotterdam.

Gourdon, J. (2014). CEPII NTM-MAP: A tool for assessing the economic impact of non-tariff measures (No. 2014-24).

Heller, G. Z., Mikis Stasinopoulos, D., Rigby, R. A., \& De Jong, P. (2007). Mean and dispersion modelling for policy claims costs. Scandinavian Actuarial Journal, (4), 281-292.

Jaud, M., Cadot, O., \& Suwa-Eisenmann, A. (2013). Do food scares explain supplier concentration? An analysis of EU agri-food imports. European Review of Agricultural Economics, 40(5), 873-890.

Kallummal, M., Gupta, A., \& Varma, P. (2013). Exports of Agricultural Products from SouthAsia and Impact of SPS Measures: A Case Study of European Rapid Alert System for Food and Feed (RASFF). Journal of Economic Policy and Research, 8(2), 41.

Kleter, G. A., Prandini, A. L. D. O., Filippi, L. A. U. R. A., \& Marvin, H. J. P. (2009). Identification of potentially emerging food safety issues by analysis of reports published by the European Community's Rapid Alert System for Food and Feed (RASFF) during a four-year period. Food and Chemical Toxicology, 47(5), 932-950.

Lambert, D. (1992). Zero-inflated Poisson regression, with an application to defects in manufacturing. Technometrics, 34(1), 1-14.

Mahé, L. P. (1997). Environment and quality standards in the WTO: New protectionism in agricultural trade? A European perspective. European Review of Agricultural Economics, 24(3-4), 480-503. 
Chapter 2. Methods and concepts

McCullagh, P., \& Nelder, J. A. (1989). Generalized Linear Models, no. 37 in Monograph on Statistics and Applied Probability.

Mullahy, J. (1986). Specification and testing of some modified count data models. Journal of econometrics, 33(3), 341-365.

Ndayisenga, F., \& Kinsey, J. (1994). The structure of nontariff trade measures on agricultural products in high-income countries. Agribusiness, 10(4), 275-292.

Otsuki, T., Wilson, J. S., \& Sewadeh, M. (2001). Saving two in a billion: quantifying the trade effect of European food safety standards on African exports. Food policy, 26(5), 495514.

Ridout, M., Demétrio, C. G., \& Hinde, J. (1998). Models for count data with many zeros. In Proceedings of the XIXth international biometric conference, 19, 179-192.

Sykes, A. O. (1995). Product standards for internationally integrated goods markets. Brookings Institution Press.

UNCTAD (2010). Non-tariff Measures: Evidence from Selected Developing Countries and Future Research Agenda, United Nations Conference on Trade and Development. Ginebra.

Wilson, J. S., \& Otsuki, T. (2004). To spray or not to spray: pesticides, banana exports, and food safety. Food Policy, 29(2), 131-146.

Winkelmann, R. (2004). Health care reform and the number of doctor visits - an econometric analysis. Journal of Applied Econometrics, 19(4), 455-472.

WTO (2012), Looking beyond International Cooperation on Tariffs: NTMs and services Regulations in the XXIst Century, World Trade Organization, Geneva.

Zeileis, A., Kleiber, C., \& Jackman, S. (2008). Regression models for count data in R. Journal of Statistical Software, 27(8), 1-25. 
Sanitary and Phytosanitary measures in agri-food imports from the European Union: Reputation effects over time 


\section{Co-author letter}

UNIVERSITAT

POLITĖCNICA

DE VALÉNCIA

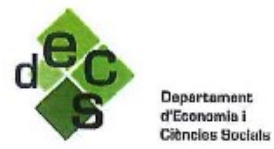

Valencia, 3 february2017

Mr. Victor Martinez-Gomez Co-author of the publication: Sanitary and Phytosanitary measures in agri-food imports from the European Union: Reputation effects over time, published in the journal Economía $\Lambda$ graria y Recursos Naturales, Declares that he agrees with the presentation by the doctoral candidate, Ibtissem Taghouti, of this publication as part of the doctoral thesis; additionally expresses his renounce to the use of this work as part of other doctoral thesis.

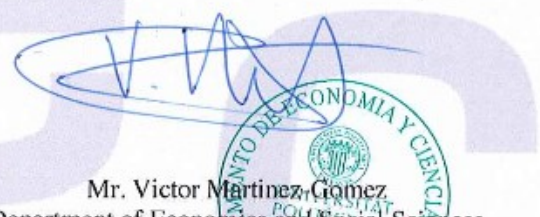

Department of Econonics and Social Sciences

Universitat Politénica de Vafénciås
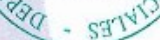

Departament d'Economia i Ciències Socials

Cami de Vera, s/n. A6022 VALENCIA. Tel.963877470. Fax.963877479.E-mail: decs@upvnet.upv.es www.upv.esłentidadesłDECS

Source: Department of Economics and Social Sciences; Dr. Victor Martinez-Gomez 
Chapter 3. Sanitary and Phytosanitary measures in agri-food imports from the European Union: Reputation effects over time

\section{Co-author letter}

UNIVERSITAT

POLITECCNICA

DE VALĖNCIA

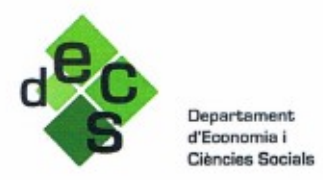

Valencia, 3 february 2017

Ms: Luisa Marti Co-author of the publication: Sanitary and Phytosanitary measures in agri-food imports from the European Union: Reputation effects over time, published in the journal Economía Agraria y Recursos Naturales, Declares that she agrees with the presentation by the doctoral candidate of this publication as part of the doctoral thesis; additionally expresses her renounce to the use of this work as part of other doctoral thesis.

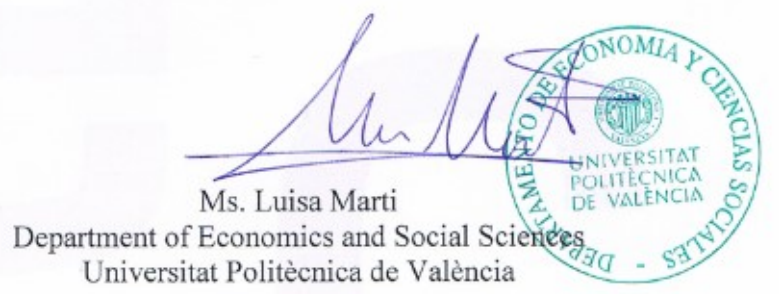

Departament d’Economia i Ciències Socials

Cami de Vera, s/n.46022 VALENCIA.Tel.963877470.Fax.963877479.E-mail: decs@upvnet.upv.es

www.upv.es\entidades\DECS

Source: Department of Economics and Social Sciences; Dr. Luisa Marti 
Chapter 3. Sanitary and Phytosanitary measures in agri-food imports from the European

Union: Reputation effects over time

\section{Sanitary and Phytosanitary measures in agri-food imports from}

\section{the European Union: Reputation effects over time ${ }^{4}$}

Ibtissem Taghouti ${ }^{1}$

Victor Martinez-Gomez ${ }^{1}$

Luisa Marti ${ }^{1}$

${ }^{1}$ Department of Economics and Social Sciences;

Group of International Economics and Development;

UPV-UniversitatPolitècnica de València, Spain

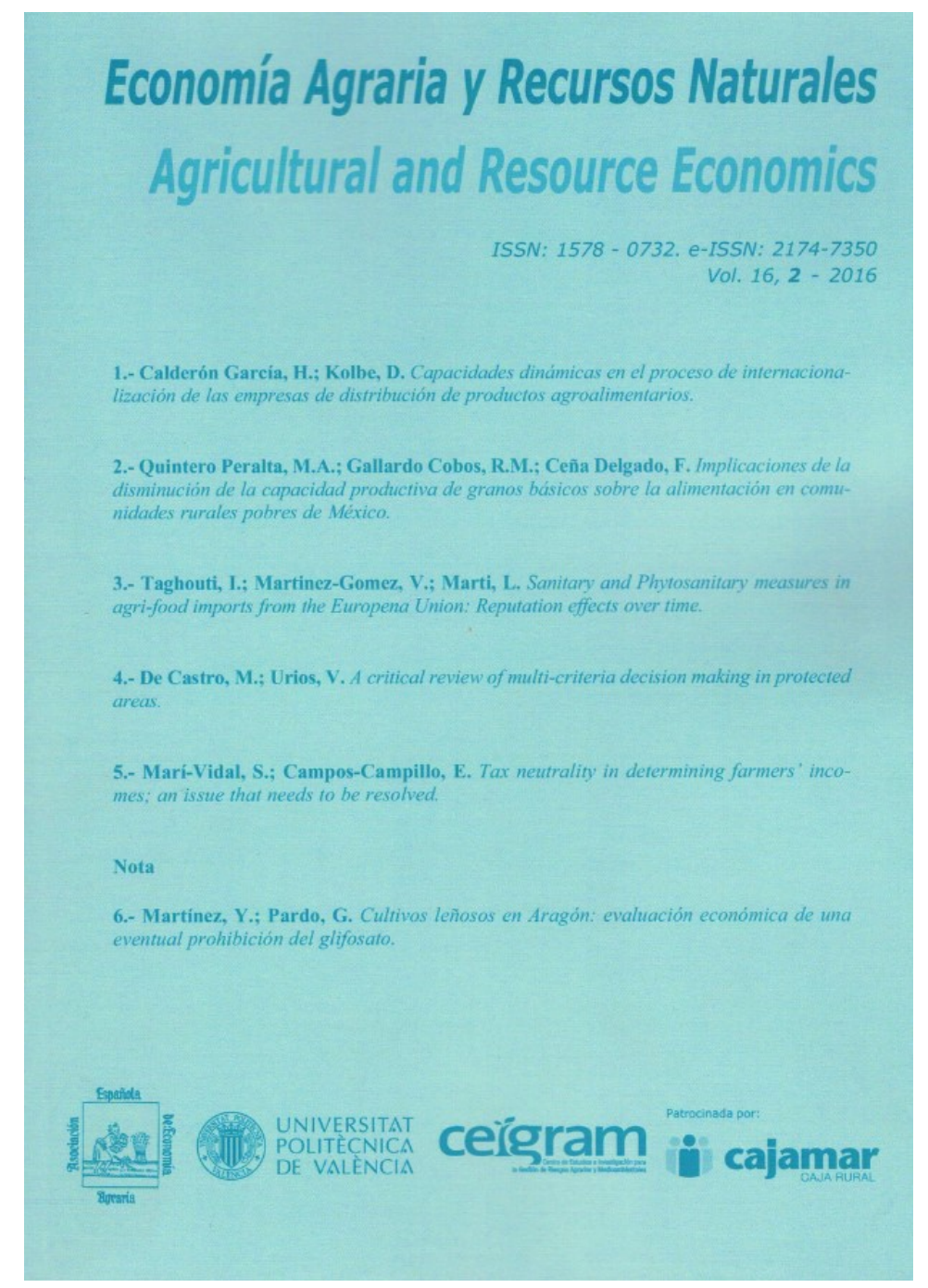

${ }^{4}$ It was published in the Agricultural and Resource Economics journal in 2016, volume 16, number 2, pages 69-

88. DOI : http://dx.doi.org/10.7201/earn.2016.02.03 


\title{
Chapter 3. Sanitary and Phytosanitary measures in agri-food imports from the European Union: Reputation effects over time
}

\begin{abstract}
The EU's Rapid Alert System for Food and Feed provides information on sanitary and phytosanitary (SPS) notifications. With a set of data from the 1998-2013 period, we test the hypothesis that past notifications can determine current notifications. This is the "reputation effect", meaning that inspectors may tend to target products or countries with previous SPS problems. We analyze the scope of the reputation effect over time. We used two count data models to estimate the distribution of current notifications. In line with previous literature, our findings indicate that reputation does affect current EU notifications. Furthermore, we identify some relevant exporter countries for which reputation is long-lasting.
\end{abstract}

KEYWORDS: Agri-food trade, Count models, RASFF, Reputation effect, SPS measures. JEL classification : F13, F14, Q17, Q18.

\subsection{Introduction}

Non-Tariff Measures (NTMs) are practices that alter the conditions of international trade, including those measures that restrict it as well others that incentivize it. Prices as well as traded quantities are altered as a result of those practices. Economic literature has treated Extensively NTMs in recent decades. One line of discussion refers to the political economy behind the implementation of NTMs in different countries. Some analysts argue that NTMs are implemented to guarantee high quality and compliance with technical standards (Mahé, 1997; Disdier et al., 2015); in this vein, Henson and Jaffee (2008) employed the expression "standards as catalysts", stating that the standards help to correct market failures, while others point to protectionist reasons. For instance, one classical hypothesis is the existence of "policy substitution" (Copeland, 1990; Ederington, 2001; Bagwell and Staiger, 2001). Its proponents argue that, together with multilateral tariff cuts, countries may implement NTMs to secure a certain level of protection for domestic production.

Therefore, to ascertain the trade-enhancing or trade-deterrent role of NTMs, some recent researches have investigated how NTMs affect the agri-food trade (Cadot et al., 2012; Yue and Beghin, 2009). A point to stress is that limited access to consistent and updated information and various methodology limitations make the estimation of the NTM impacts on 
Chapter 3. Sanitary and Phytosanitary measures in agri-food imports from the European Union: Reputation effects over time

the agri-food trade a hard task. Another point to stress, based on literature findings, is that the trade-enhancing and trade-deterrent effects found empirically are very often country- and sector-specific (Dal Bianco et al., 2015). For instance, fresh and processed food are not significantly affected by these measures (Fontagné et al., 2005).

A specific category of NTMs includes border measures "...such as restriction for substances and ensuring food safety, and those for preventing dissemination of disease or pests as well as all conformity-assessment measures related to food safety, such as certification, testing and inspection, and quarantine" (UNCTAD, 2015; p.4). These kinds of NTMs which are termed are the so-called Sanitary and Phytosanitary (or SPS) Measures. Many actors are involved in the definition of specific SPS measures (policymakers, producers' and consumers' organizations, environmental associations, etc.) which is why these measures tend to be very diverse across countries and their application is usually a very dynamic and complex process. Consequently, complying with SPS rules can be a challenge for trading partners.

Over the past few decades, food scares have become a recurring theme in the European Union (EU). Food safety standards in the EU are therefore becoming more stringent in order to limit the risks associated with contaminated food products. Sanitary concerns are more relevant for products like fruits and vegetables or fisheries products (Jaud et al., 2013). Indeed, consumer health has become a key concern in EU public health policies, a fact which in turn could influence the EU's preferences in supplier selection (Taghouti et al., 2015). Such concerns have the potential to influence the evolution of EU agri-food imports, and therefore limit market access for suppliers who have difficulties in complying with EU sanitary standards.

In the EU, SPS border measures are defined at the EU level, so that common sanitary and safety standards for food products are set for the EU as a whole, while national border authorities have the responsibility to control whether or not imports meet the established standards. There are some issues related to these controls that deserve special attention. In fact, limited resources to inspect all imported agri-food products can lead to under-inspection as well as over-inspection. The past can determine which products are controlled, as inspectors might primarily target products that have had problems in the past or countries with a high probability of having problems to export certain products identified as sensitive in previous inspections. As discussed in the next section, a considerable amount of literature has focused on this "reputation effect". 
Chapter 3. Sanitary and Phytosanitary measures in agri-food imports from the European Union: Reputation effects over time

As a tool to raise awareness across MS about compliance with SPS rules by food imports, the European Rapid Alert System for Food and Feed (RASFF) provides information in the form of notifications that indicate when, where and why there are food alerts or border rejections of a specific consignment. In this paper, we use this database to analyze the EU's behaviour in the implementation of food safety standards at its borders.

Against this background, the main objective of our paper is to explore the reputation effect in the case of European agri-food imports by testing whether past notifications somehow influence current notifications. More specifically, we want to ascertain, in the first place, whether this reputation exists or not and, if so, we aim to identify and address other questions that can help us gain an insight into the topic: Are there differences in the "trade effect" of reputation across countries? What are the influencing factors that determine the reputation of a given product or country in agri-food trade? Does reputation evolve over time for a given country?

The rest of this paper is structured as follows. The next section introduces the notion of reputation at product, sector and country level, departing from a discussion of existing literature in this respect. We then explain and discuss the methodology chosen for the analysis. The results section shows the relevance of reputation on SPS control at the EU borders according to the empirical findings and, after that, we set out the main conclusions drawn from the empirical analysis.

\subsection{The notion of reputation}

The term "reputation" has been recently employed in literature regarding the implementation of SPS measures. This section reviews the emerging literature in this area. First, we explore and define the notion of reputation when analysing trade in agri-food products. Then we extend the discussion by highlighting the importance of considering the effect of reputation over time, which involves differentiating and comparing its effects in the short and the long run.

The notion of reputation was first introduced by Jouanjean et al. $(2012$; 2015) by examining the behaviour of the United States (US) in rejecting agri-food products at its frontiers. The above-mentioned authors tested the hypothesis that the border rejections for a product coming from a certain exporter in a given year could raise the probability of future rejections for the same product and origin, and they called this effect "reputation". Their results confirmed the hypothesis, i.e. previous-year notifications increase the probability of 
Chapter 3. Sanitary and Phytosanitary measures in agri-food imports from the European Union: Reputation effects over time

notifications in the current year. Hence, Jouanjean et al. (2015) suggested that NTMs are not only implemented on the basis of current risk, but are also influenced by past risks.

Jouanjean et al.'s methodology involved codifying the US refusals with an aggregation by country of origin and product (classified with 4-digit HS code ${ }^{5}$ ) over the period 19982008. Additionally to this "product-country" reputation, their paper distinguishes a "region" and a "sector" reputation effect. For the "region" reputation, they tested the hypothesis that if a product from a neighboring country -i.e. belonging to the same "region"- was refused in the previous year, then the number of refusals for the exporting country in the current year could be expected to increase for the same product. As for the "sector" reputation, the same holds true when considering the aggregation of products at the two-digit level (HS2): the odds of a refusal increase if a product from the same sector-i.e. belonging to the same HS2 chapter was notified in the previous year.

Taghouti et al. (2015) explored EU food safety notifications on agri-food imports, giving special attention to Mediterranean Partner Countries (MPCs). Four types of reputation were considered, namely product, sector, country and region reputations. The results showed that EU notifications are affected mainly by a product's own reputation as well as by the country's reputation. Besides, the study showed no sign of protectionist behaviour by the EU against MPCs, even taking into account products that compete with domestic production.

The results from Tudela-Marco et al. (2016) highlight the fact that EU MS have no common behavior in implementing border controls for fruits and vegetables. Tudela-Marco et al.'s study supports the evidence found by Jouanjean et al. (2015) and Taghouti et al. (2015) with regard to reputation. Product reputation appears to be more significant in comparison to sector and country reputation. Furthermore, the results of the above-mentioned study showed a strong correlation between the degree of development of exporting countries and the number of notifications.

The main conceptual contribution of the present paper is to extend the concept of reputation to cover a longer time span. In existing literature, product reputation appears to be the most influential. However, to date, the impact of reputation has been checked only over a one-year period, and our starting hypothesis is that this effect might be longer-lasting. So, we will check not only whether notifications in a given year affect notifications the following

\footnotetext{
5 HS refers to the Harmonized System, a standard international system for classifying goods in international trade, adopted in the late $1980 \mathrm{~s}$.
} 
Chapter 3. Sanitary and Phytosanitary measures in agri-food imports from the European

Union: Reputation effects over time

year, but we will also examine whether product reputation extends backwards in time up to the third preceding year. A further contribution is that we consider fixed country effects in order to examine whether SPS border treatment differs for different exporters.

\section{Data and descriptive analysis}

As mentioned in the introduction, RASFF is a system of notification and information exchange on emergency sanitary measures at the border of EU MS. It provides information on food notifications at the EU's borders, specifying which shipments of specific products from exporting countries do not comply with food safety requirements ${ }^{6}$.

This data source has been used previously in order to analyze the impact of SPS measures on the agri-food trade. In particular, Kleter et al. (2009) explored the usefulness of RASFF notifications to identify emerging trends in recent food safety issues, based on EU reports. For their part, Jaud et al. (2013) examined the RASFF notifications of 146 exporters to the EU in order to determine the geographical concentration of EU agri-food imports; and Kallummal et al. (2013) used the RASFF database to analyze the impact of EU food safety measures on trade flows between South Asian countries and the EU as a whole.

In our case, in order to analyze the effect of reputation on EU food import notifications, we used an original database of 39 countries $^{7}$ selected on the grounds that they are the most notified partners by the EU in the period under consideration. Overall, these countries' exports received 15,098 notifications, which account for $34 \%$ of total notifications in the period 1998 to $2013^{8}$ and which we took as the starting point for our research: It should be noted that the RASFF portal provides a complete database with product information in verbal form, but notifications are not classified under the Harmonized System. Our study includes imports from $\mathrm{EU} \mathrm{MS}^{9}$, and all the notifications found belonging to the selected countries were painstakingly classified with 4-digit HS codes. The biggest challenge we faced when building this database was converting all the recorded product notifications from verbal form to HS code. To do so, we designed a word-recognition algorithm complemented by user assessment for ambiguous verbal forms.

\footnotetext{
${ }^{6}$ In addition to the EU, the four European Free Trade Association countries are also RASFF members.

7 Argentina, Australia, Brazil, Canada, Chile, China, Colombia, Costa Rica, Cote d'Ivoire, Ecuador, Egypt, Ethiopia, Ghana, Guatemala, Iceland, India, Indonesia, Israel, Japan, Korea, Malaysia, Mauritania, Mexico, Morocco, Namibia, New Zealand, Nigeria, Norway, Pakistan, Peru, Philippines, Russia, Saudi Arabia, South Africa, Thailand, Turkey, Ukraine, United States and Vietnam.

8 We chose a 15-year period, considering that the last data available were from 2013 when the codification was made. Overall, there were 44,502 notifications.

9 We took into account the imports of the former EU-15 MS to ensure consistency and coherence over a long period.
} 
Chapter 3. Sanitary and Phytosanitary measures in agri-food imports from the European Union: Reputation effects over time

Each notification was coded specifying all of the following parameters: the identity of the exporting country, the notified product, the sector, and the date of notification. The unit of observation is defined as "product (HS4), exporter country, year of the notification". For further analysis, notifications are summed over notified products of the same sector (HS2) and over notified products of each country to take into account the notifications per sector and per country in each year of the sample.

It is important to make two remarks: First, products enter the database only if they are exported to the EU15. This has implications for the type of zeroes found in the database (see below). Secondly, we included all the notifications for agri-food products except those of the first HS chapter (HS01: Live animals) and HS24 (Tobacco and manufactured tobacco substitutes).

Figure 1 shows the evolution over time of the number of notifications. The total number of notifications shows a sharply rising trend starting in 1998, with the curve levelling off after 2007. Indeed, in the first period (before 2007) the total number of notifications rose yearly by $26.27 \%$ while after 2007 this figure dropped to $9 \%$. The average number of notifications in the current year ( $\mathrm{t}$ ) is 944 , in one lagged year 868, two lagged years 783 , and three lagged years 695 .

While we do not specifically analyze this aspect in our paper, some explanation on the type of notifications issued may be appropriate. There are different types of notifications, depending on the action taken: alert notifications, information and news notifications, and border rejections. They are indicators about which exporting countries and products fulfill the food safety and quality standards required by EU (RASFF, 2013). In accordance with the Regulation (EC) No 16/2011, an alert notification is defined as an information sent when a food or feed presenting a serious health risk on the market has to be treated with priority. Information notifications are used when a risk has been detected about food or feed placed on the market, but the other members do not have to handle it quickly. Besides, any information related to the safety of food and feed products which has not been transmitted as an alert or an information notification, but which is considered interesting for the control authorities, is sent

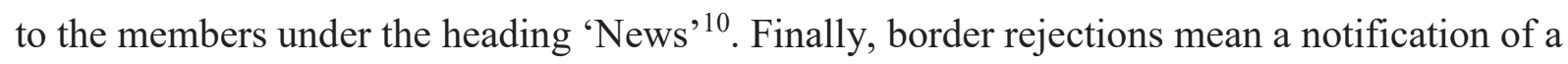
rejection in respect with food and feed consignments that have been tested and rejected at the external borders of the EU when a health risk has been identified.

\footnotetext{
${ }^{10}$ For this reason, we plot News and Information together.
} 
Chapter 3. Sanitary and Phytosanitary measures in agri-food imports from the European Union: Reputation effects over time

Over $36 \%$ of notified products were rejected at the borders of the EU in the period 1998-2013. $51.5 \%$ of total notifications were information notifications. Figure 1 illustrates the changes for different types of notifications: in addition to the increase in the total number of notifications since the early 2000s, a change took place from 2007 onwards, i.e. a shift from information to the more restrictive category -rejections-is apparent. While this is probably linked to the above-mentioned greater concern for food safety, it clearly also points to a more restrictive implementation of SPS measures at the EU borders.

Figure 2 shows a significant level of heterogeneity among notifying EU MS in terms of their respective share of the total number of notifications, based on averages over the period 1998-2013. Italy (16.4\%), United Kingdom (16.4\%) and Germany (16.3\%) are the top notifying countries. This fact might reflect the different agri-food imports structure and volumes among EU MS. It could also indicate inspections are not operated uniformly across the EU, as the findings from Tudela-Marco et al. (2016) suggest.

Figure 1. Evolution in the number of notifications and breakdown by type (1998-2013)

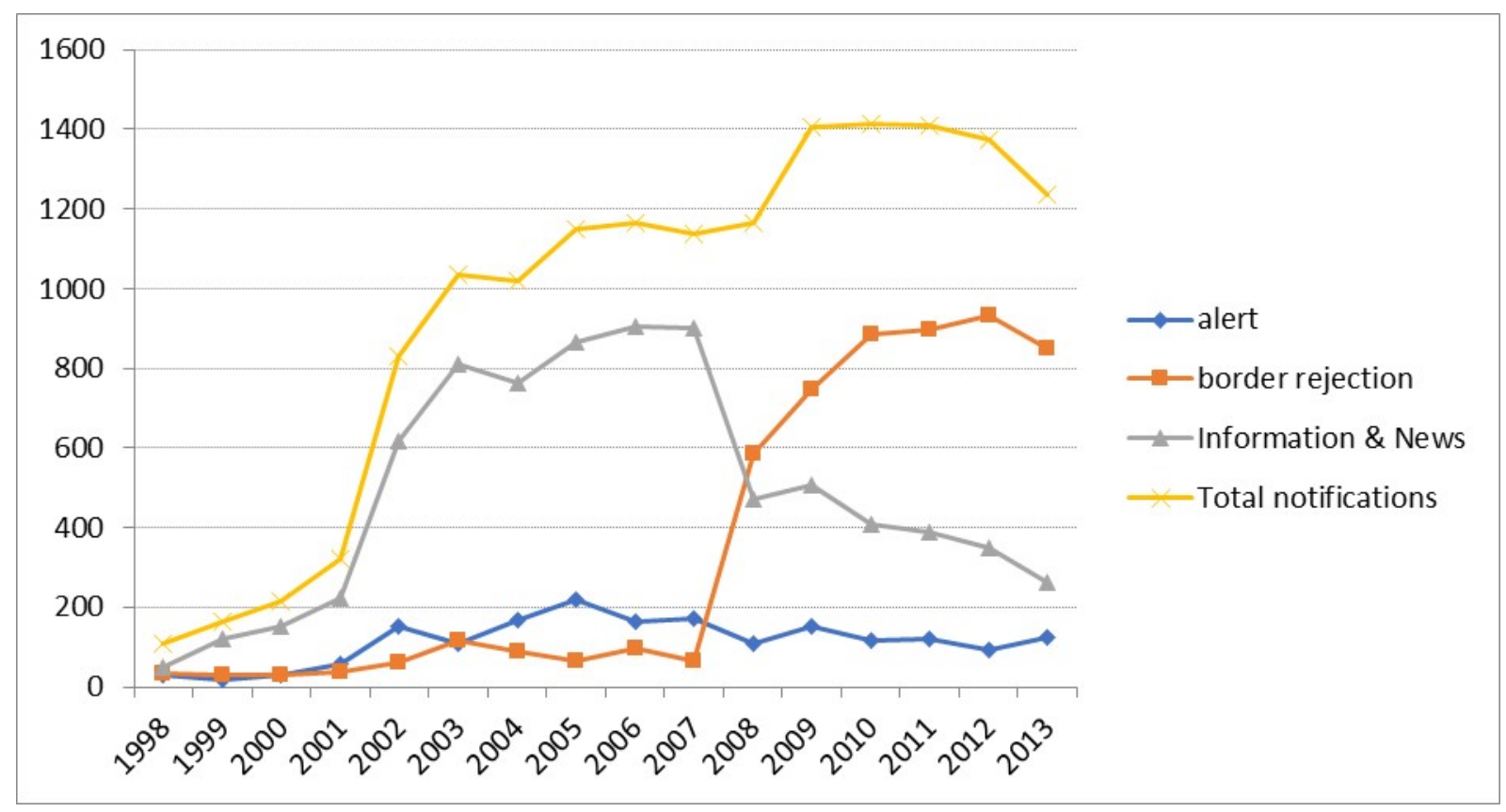

Source: Authors' calculations based on RASFF data 
Chapter 3. Sanitary and Phytosanitary measures in agri-food imports from the European Union: Reputation effects over time

Figure 2. Percent of total notifications by Member State (1998-2013)

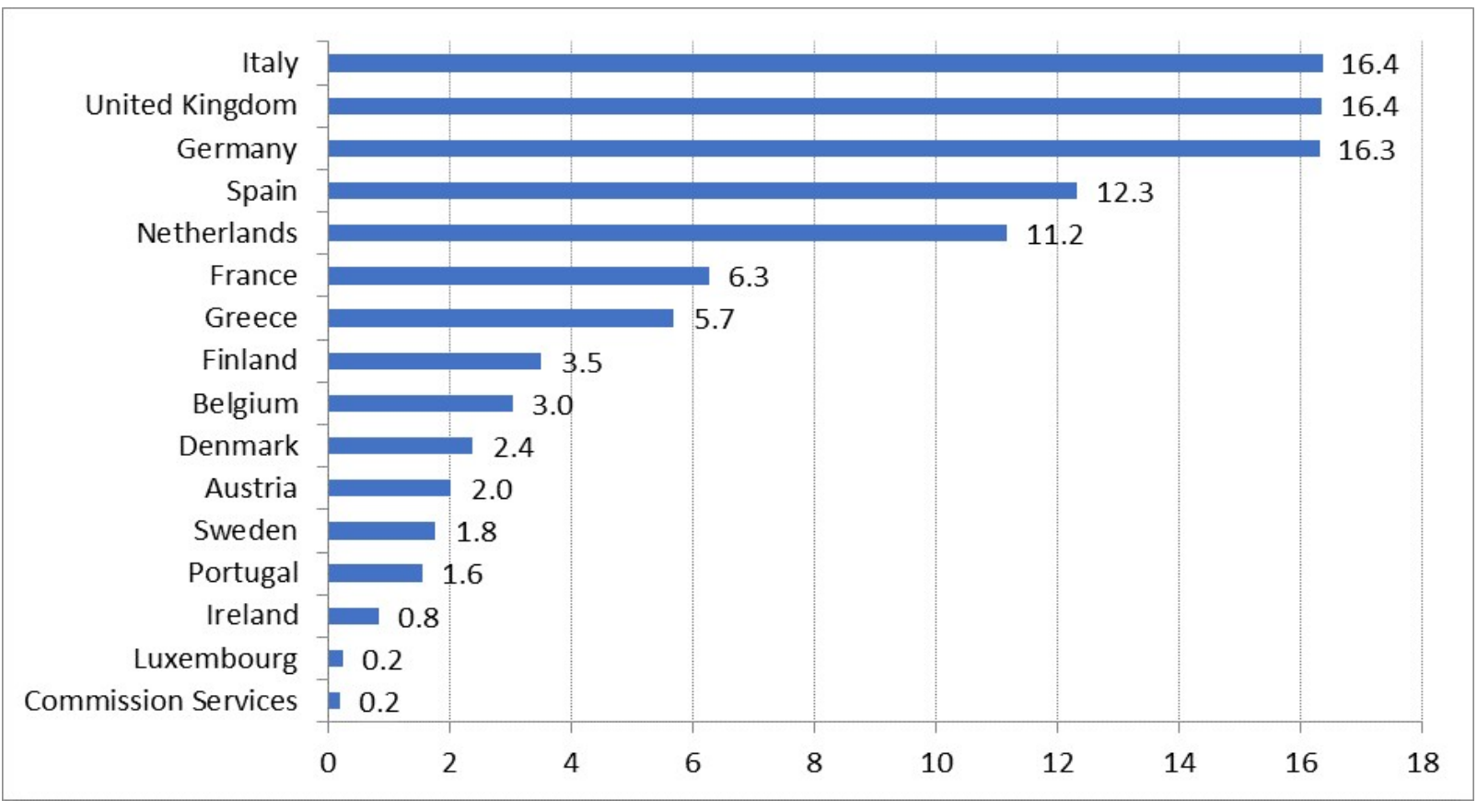

Source: Authors' calculations based on RASFF data

Figure 3 depicts the heterogeneity among countries that receive notifications. Apart from Turkey, countries most affected by notifications are the two largest Asian countries, followed by the United States. Turkey accounts for $16.1 \%$ of observations, followed by China (15.8\%), India (11.1\%) and the US (7.9\%).

Figure 4 shows the frequency of notifications for each agri-food sector. The most notified sectors are "Fish and crustaceans" (HS03) and "Fresh fruits" (HS08), each accounting for more than one fifth of total notifications in our database. These sectors are followed by HS chapters 12 (Oil seeds and oleaginous), HS 09 (Coffee, tea and spices) and 07 (Vegetables). 
Chapter 3. Sanitary and Phytosanitary measures in agri-food imports from the European Union: Reputation effects over time

Figure 3. Percent of total notifications by country ${ }^{11}$, (average 1998-2013)

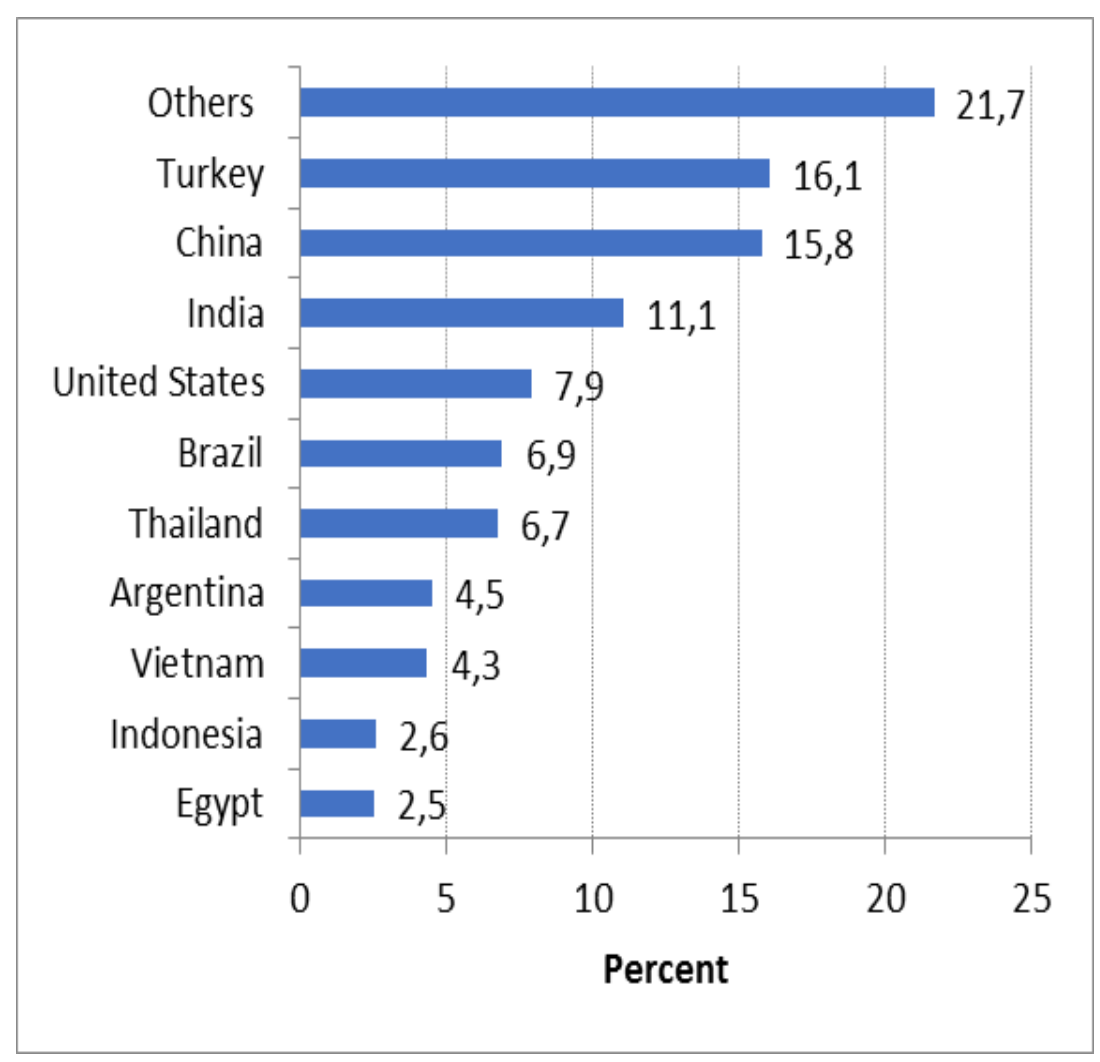

Source: Authors' calculations based on RASFF data

\footnotetext{
${ }^{11}$ Top 10 notified countries
} 
Chapter 3. Sanitary and Phytosanitary measures in agri-food imports from the European

Union: Reputation effects over time

Figure 4. Percent of total notifications by Harmonized System 2 chapter $^{12}$, (average 19982013)

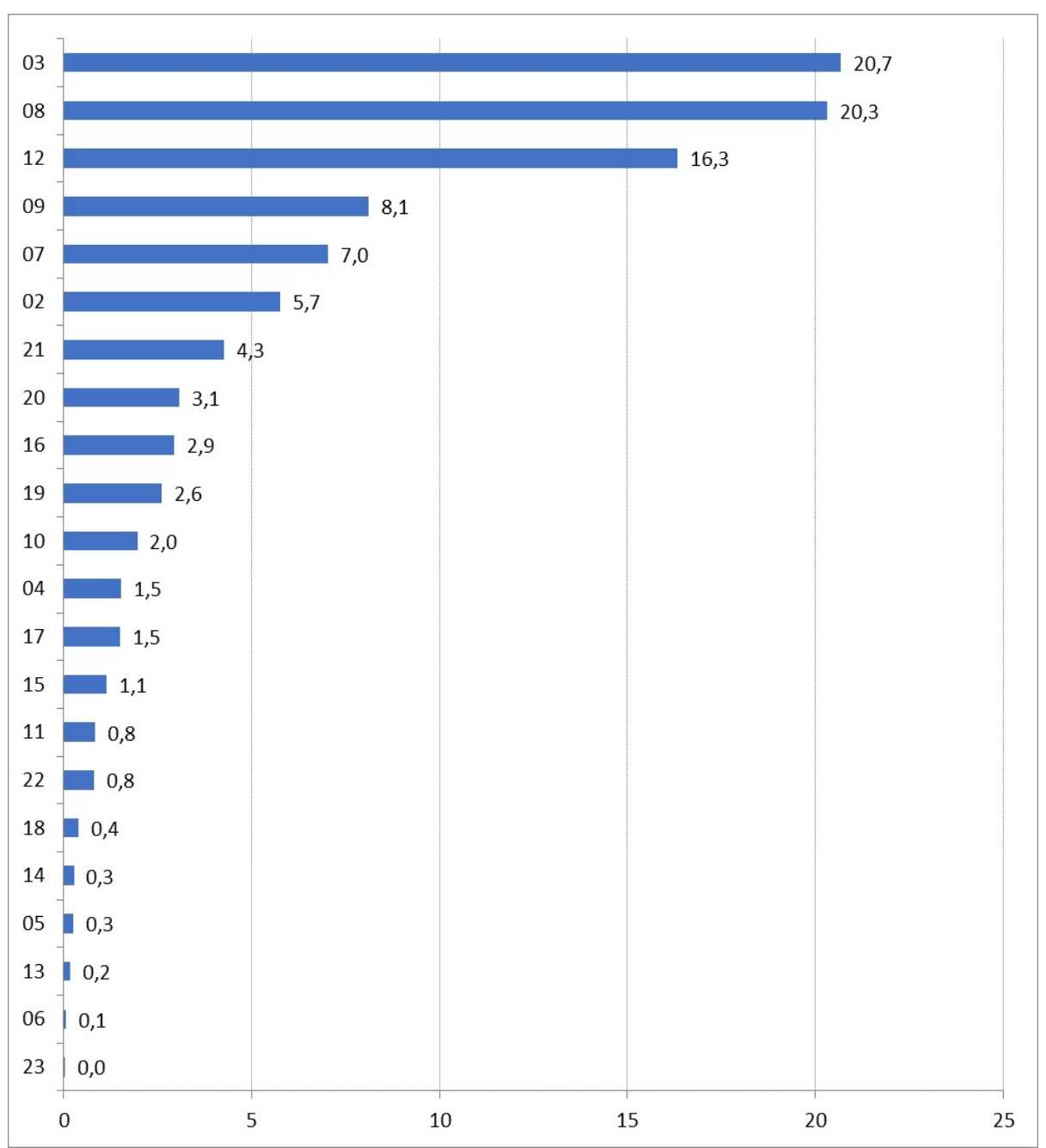

Source: Authors' calculations based on RASFF data

12 01: Live animals; 02: Meat and edible meat offal; 03: Fish and crustaceans, molluscs and other aquatic invertebrates; 04: Dairy products, birds' eggs, natural honey, edible products of animal origin; 05: Animal originated products; 06: Trees and other plants, live, bulbs, roots and the like, cut flowers and ornamental foliage; 07: Vegetables and certain roots and tubers; 08: Fruit and nuts, Peel of citrus fruit or melons; 09: Coffee, tea, mate and spices; 10: Cereals; 11: Products of the milling industry, malt, starches, inulin, wheat glute; 12: Oil seeds and oleaginous fruits, Miscellaneous grains, seeds and fruit, industrial or medicinal plants, straw and fodder; 13: Lac, gums, resins and other vegetable saps and extracts; 14: Vegetable plaiting materials, vegetable products; 15: Animal or vegetable fats and oils and their cleavage products, prepared animal fats, animal or vegetable waxes; 16: Meat, fish or crustaceans, molluscs or other aquatic invertebrates; preparations thereof; 17 : Sugars and sugar confectionery; 18: Cocoa and cocoa preparations; 19: Preparations of cereals, flour, starch or milk, pastrycooks' products; 20: Preparations of vegetables, fruit, nuts or other parts of plants; 21: Miscellaneous edible preparations; 22: Beverages, spirits and vinegar; 23: Food industries, residues and wastes thereof 
Chapter 3. Sanitary and Phytosanitary measures in agri-food imports from the European Union: Reputation effects over time

\subsection{Methodology and model specification}

Given the definition of all notifications types (see the previous section), it is important to stress that we assume that the reputation of a product or an exporting country can be affected by any type of information transmitted by the RASFF network. Therefore, in the present study the number of notifications includes all types of notifications. This choice also relies on previous studies carried out by several authors (Kleter et al., (2009); Jaud et al., (2013); Kallummal et al., (2013); Garcia Alvarez-Coque et al., (2015); Jouanjean et al., (2012, 2015)). These authors use notifications as dependent variable to determine the impact of SPS measures on agro-food trade. Also, the number of notifications is widely used as a measure to analyze the behavior of countries in respect with the implementation of food safety standards on vegetable and animal products.

Given that we chose as the dependent variable the number of notifications for a given product (i) from an exporter (j) in year ( $\mathrm{t}$ ) as $\mathrm{N}_{\mathrm{ijt}}$, the empirical analysis developed in this section is based on three types of reputation, i.e. we count the number of notifications per product, sector and country:

- "Product reputation" $\left(\mathrm{N}_{\mathrm{ij}(\mathrm{t}-\mathrm{k})}\right)$ is defined by the correlation between the number of notifications for a given "product-exporter-year" combination $\mathrm{N}_{\mathrm{ijt}}$ and the number of notifications for that "product-exporter" in the previous years $\mathrm{N}_{\mathrm{ijt}-\mathrm{k}}$. If $\mathrm{k}=1$, we consider the influence of notifications for that "product-exporter" in the previous year $\mathrm{N}_{\mathrm{ijt}-1}$. We will label this as the short-term reputation. ${ }^{13}$ If $\mathrm{k}=2$, we will refer to the influence of notifications for that "product-exporter" in the second previous year $\mathrm{N}_{\mathrm{ijt}-2}$.We will label this as the mediumterm reputation. If $\mathrm{k}=3$, we consider the number of notifications for that "product-exporter" in the third previous year $\mathrm{N}_{\mathrm{ijt}-3}$. This will be indicative of a long-term reputation.

-"Sector reputation" $\left(\mathrm{N}_{\mathrm{lj}(\mathrm{t}-1)}\right)$ refers to the influence on the number of notifications, for a given "product-exporter-year" combination $\mathrm{N}_{\mathrm{ijt}}$, exerted by the number of notifications for all products belonging to the same HS2 chapter for that exporter in one lagged year $\mathrm{N}_{\mathrm{Ij}(\mathrm{t}-1) \text {. }}$

- "Exporter reputation" $\left(\mathrm{N}_{\mathrm{J}(\mathrm{t}-1)}\right)$ represents the influence on the number of notifications, for a given "product-exporter-year" combination $\mathrm{N}_{\mathrm{ijt}}$, exerted by the total number of notifications applied to the same exporter in the previous year.

\footnotetext{
${ }^{13}$ This is the product reputation studied previously in the available literature.
} 
Chapter 3. Sanitary and Phytosanitary measures in agri-food imports from the European Union: Reputation effects over time

As an additional explanatory variable, the database includes the one-year lagged per capita Gross Domestic Product (GDPpc) of each country of origin, based on World Bank data, at constant 2005 prices in US dollars. This variable is collected to take into account whether EU control of imported agri-food products is influenced by the level of development of the country of origin. The underlying assumption, as suggested by Taghouti et al. (2015), is that richer countries are less likely to fail a SPS control, due to more developed pre-export facilities and, in general, to a more export-oriented value chain.

We also consider the possibility of protectionist behavior, with over-control after an export surge of a product, by including among the explanatory variables the previous year value of imports for that product - extracted from COMEXT-EUROSTAT data. The model specification is shown in Equation [1]:

$$
\begin{aligned}
& N_{i j t}=\exp \left[\delta_{0}+\sum_{k=1}^{3} \delta_{k} \beta_{1} N_{i j t-k}+\varphi\left(N_{l j t-1}\right)+\theta\left(N_{j t-1}\right)+\rho\left(\ln G D P_{p c j(t-1)}\right)+\right. \\
& \left.\sigma\left(\ln \text { Import } t_{i(t-1)}\right)+\sum_{j=1}^{10} \beta_{j} Z_{j}+\sum_{j=1}^{10} \sum_{k=1}^{3} \gamma_{j k} Z_{j} N_{i j(t-k)}\right]
\end{aligned}
$$

Where $\delta_{k^{z}} \varphi_{i} \theta_{z} \rho_{z} \sigma_{z} \beta_{j}, \gamma_{j k}$ represent the coefficients of the explanatory variables to be estimated, and $Z_{j}$ is a dummy variable that takes the value of 1 for country (j) and zero otherwise. $Z_{j}$ represents the fixed effects of the 10 main agri-food exporters among the 39 selected countries. This fixed effect is understood to consist of a distinctive shift for those countries in comparison with the general effect of notifications ${ }^{14}$.

By examining the descriptive statistics of the set of variables, we note that the standard deviation of almost all variables is greater than the mean, which suggests that over-dispersion can be a problem for the econometric estimation. Another challenge posed by the data is the enormous amount of zero observations (no notifications for a given "product-origin-year"). ${ }^{15}$

\footnotetext{
${ }^{14}$ Fixed product effects could not be estimated as convergence issues were insurmountable. The analysis of the most notified products (e.g., nut products) will constitute another area that merits further attention as a case study, so that the main factors that can affect product reputation can be identified.

${ }^{15}$ In fact, there are 126,720 observations from the 15,098 notifications.
} 
Chapter 3. Sanitary and Phytosanitary measures in agri-food imports from the European Union: Reputation effects over time

These facts point to the need for effective count models to accurately estimate the relationship given in (1). Table 3 shows the descriptive statistics of the variables used in our estimation.

Table 3. Descriptive statistics

\begin{tabular}{|l|l|l|l|l|l|}
\hline Variable & Mean & Std. Dev & Min & Max & \% of "zeroes" \\
\hline $\mathrm{N}_{\mathrm{ijt}}$ & 0.12 & 1.694 & 0 & 140 & 97.0 \\
\hline $\mathrm{N}_{\mathrm{ijt}-1}$ & 0.11 & 1.620 & 0 & 140 & 97.1 \\
\hline $\mathrm{N}_{\mathrm{ijt}-2}$ & 0.10 & 1.513 & 0 & 140 & 97.4 \\
\hline $\mathrm{N}_{\mathrm{ijt}-3}$ & 0.09 & 1.438 & 0 & 140 & 97.7 \\
\hline $\mathrm{N}_{\mathrm{ijt}-1}$ & 1.16 & 7.454 & 0 & 210 & 83.2 \\
\hline $\mathrm{N}_{\mathrm{tt}-1}$ & 21.72 & 43.721 & 0 & 294 & 18.1 \\
\hline Ln GDP $\mathrm{pc(t-1)}$ & 8.32 & 1.476 & 4.850 & 11.120 & 0 \\
\hline Ln Import $(\mathrm{t}-1)$ & 1 & 0.064 & 1 & 15 & 0 \\
\hline
\end{tabular}

The available literature indicates that count variables follow a Poisson or one of its related distributions. However, the standard Poisson model is very sensitive to problems of over-dispersion and excess zeros in the dependent variable (Burger et al., 2009). Therefore, we estimate the previous equation with two different count models: The Negative Binomial model (NB) and the Zero-Inflated Negative Binomial model (ZINB). These models are commonly used to deal with count variables in social sciences (Zeileis et al., 2008). The model depicted in [1], estimated with the ZINB, is called ZINB1, and when estimated with NB is called NB1.

The NB belongs to the family of modified Poisson models. It is commonly used to correct the over-dispersion problem (Cameron and Trivedi, 2013). The ZINB is widely used for modeling over-dispersed count data with excessive zeros (Lambert, (1992); Greene, (1994)). This model consists of a modified version of the NB. It is assumed that the zeroes present in the database can have two possible generation processes: one groups together only "strict" zeroes, i.e. if there is no trade flow for a "product-country", it is not possible to record a notification. The second generation process corresponds to a situation of full compliance with SPS rules by actual trade flows. In this case, no notification is reported, although a notification might, possibly, have been issued. Formally, the first process is modeled with a 
Chapter 3. Sanitary and Phytosanitary measures in agri-food imports from the European Union: Reputation effects over time

logit model to consider the probability of zeroes with no possible notifications. The second process is a NB regression for the non-zero probability cases detected in the logit model.

In spite of the existence of the ZINB, the NB estimation does not have to be set apart beforehand. Cameron and Trivedi (2010) warn researchers that, in datasets with excess zeroes, the ZINB does not always fit the data better than the NB does. Statistical tests therefore have to be applied to select the best model. Furthermore, following Garcia et al. (2015), we added a restricted model in order to select which model could minimize the loss in fit with the data. This new model is a nested version of the saturated model [1] and assumes there is no other influence of previous' years notifications for the top-ten notified exporters, or $\gamma_{j k}=0$. It is given by Equation [2]:

$$
\begin{aligned}
& N_{i j t}=\exp \left[\delta_{0}+\sum_{k=1}^{3} \delta_{k} \beta_{1} N_{i j t-k}+\varphi\left(N_{l j t-1}\right)+\theta\left(N_{j t-1}+\rho\left(\ln G D P_{p c j(t-1)}\right)+\right.\right. \\
& \left.\sigma\left(\ln \operatorname{Import}_{i(t-1)}\right)+\sum_{j=1}^{10} \beta_{j} Z_{j}\right]
\end{aligned}
$$

If the restriction is true, then the loss of fit between [1] and [2] is necessarily small. The model depicted in [2], estimated with the ZINB, is called ZINB2, and when estimated with NB is called NB2. The four estimations ZINB1, ZINB2, NB1 and NB2 were run using the R-language.

\subsection{Results}

The logic behind using several autoregressive terms in the model is based on the assumption that reputation effect entails a lag time to be constructed. Thus, the current notification will depend on its own previous values and other explicative variables. One tangible concern with such models is to test the stationary condition. For this purpose, the Augmented Dickey Fuller (ADF) test has been conducted. This test allows determining whether a unit root is present in an autoregressive model which can lead to biased statistical inference.

Under the null hypothesis, $\mathrm{H}_{0}$, unit root exists that means data are non-stationary while the alternative $\mathrm{H}_{1}$ indicates that process has no unit root and data are stationary. The ADF test statistic is -157.48 . (p-value $=0.01)$. Hence, at the $5 \%$ level of significance, we reject the null hypothesis that data is non-stationary. 
Chapter 3. Sanitary and Phytosanitary measures in agri-food imports from the European Union: Reputation effects over time

There are various statistical methods to determine the best model choice. In this paper, three methods were utilized: the Akaike Information Criterion (AIC), the likelihood ratio test and the Vuong test. The Vuong test holds for non-nested models and is based on a comparison of the probabilities predicted by the two different estimation processes (ZINB and NB) (Vuong, 1989). Its null hypothesis is that the expected value of their log-likelihood ratios equals zero, which implies that both models are similar. The results of this test are given in Table 4, showing that the ZINB1 estimation is preferable to the NB1 estimation

Table 4. Comparison between NB1 and ZINB1 estimations. Vuong test

\begin{tabular}{|c|c|c|}
\hline & ZINB1 & NB1 \\
\hline No. of observations & 126,720 & 126,720 \\
\hline Overdispersion $(\alpha)$ & $8.811^{* * *}$ & 13.833 \\
\hline \multirow{2}{*}{ Vuong Test ${ }^{16}$} & $6.691^{* * *}$ & $7.613^{* * *}$ \\
\hline & \multicolumn{2}{|c|}{$21.063^{* * *}$} \\
\hline
\end{tabular}

Source: Authors' calculations

The AIC and the likelihood ratio are suitable to make comparisons across the nested models, hence between ZINB1 and ZINB2, on the one hand, and NB1 and NB2 on the other. Table 5 shows that these indicators provide evidence of the superiority of the ZINB1 over its more restricted version ZINB2, as NB1 outperforms NB2.

Table 5. NB and ZINB models. Quality of fit indicators

\begin{tabular}{|l|c|c|c|c|}
\hline & ZINB1 & ZINB2 & NB1 & NB2 \\
\hline AIC & $38,884.107^{* * *}$ & $39,306.805$ & $41,360.402^{* * *}$ & $41,968.189$ \\
\hline Log Likelihood & $-19,389.053$ & $-19,630.403$ & $-20,631.201$ & $-20,965.094$ \\
\hline No. of observations & 126,720 & 126,720 & 126,720 & 126,720 \\
\hline Overdispersion( $\alpha)$ & $8.811^{* * *}$ & 9.803 & 13.833 & 15.850 \\
\hline
\end{tabular}

Source: Authors' calculations

Analyzing the results presented in Table 6, we find that almost all the reputation effects are statistically significant across models. The only exception is the country reputation, which is only significant according to the NB estimation. However, the effect of the product

\footnotetext{
${ }^{16}$ The Z- statistic score is displayed for the Vuong test, which follows a standard normal distribution.
} 
Chapter 3. Sanitary and Phytosanitary measures in agri-food imports from the European Union: Reputation effects over time

reputations is substantially greater than that of the sector and country reputations. Besides, the reputation decreases as time goes by: The one-year lagged product reputation is greater than the two-year lagged product reputation, which in turn is greater than the three-year lagged product reputation. However, it is noticeable that the three-year lagged reputation is at least one order of magnitude greater than the sector and country reputations, which confirms its relevance in shaping current notifications.

Table 6. Statistical models: estimated parameters

\begin{tabular}{|c|c|c|c|c|c|}
\hline & & ZINB1 & ZINB2 & NB1 & NB2 \\
\hline \multicolumn{2}{|l|}{ (Intercept) } & $-0.2923(10.433)$ & $0.2827(41.961)$ & $0.0479(1555182.188)$ & $0.2790(1363608.163)$ \\
\hline \multicolumn{2}{|l|}{$\mathrm{N}_{\mathrm{ijt}-1}$} & $\mathbf{0 . 7 1 5 7}(0.041)^{* * *}$ & $0.4906(0.022)^{* * *}$ & $1.0963(0.021)^{* * *}$ & $\mathbf{0 . 7 2 2 0}(0.011)^{* * *}$ \\
\hline \multicolumn{2}{|l|}{$\mathrm{N}_{\mathrm{ijt}-2}$} & $\mathbf{0 . 5 5 5 5}(0.048)^{* * *}$ & $0.2339(0.023)^{* * *}$ & $0.9556(0.026)^{* * *}$ & $\mathbf{0 . 4 3 9 8}(0.014)^{* * *}$ \\
\hline \multicolumn{2}{|l|}{$\mathrm{N}_{\mathrm{ijt}-3}$} & $\mathbf{0 . 2 8 1 8}(0.047)^{* * *}$ & $\mathbf{0 . 1 6 5 0}(0.0230)^{* * *}$ & $0.6088(0.025)^{* * *}$ & $\mathbf{0 . 3 4 9 1}(0.012)^{* * *}$ \\
\hline \multicolumn{2}{|l|}{$\mathrm{N}_{\mathrm{Ijt} .1}$} & $\mathbf{0 . 0 1 7 8}(0.002)^{* * *}$ & $\mathbf{0 . 0 1 8 0}(0.0024)^{* * *}$ & $\mathbf{0 . 0 2 7 8}(0.001)^{* * *}$ & $\mathbf{0 . 0 3 0 1}(0.001)^{* * *}$ \\
\hline \multicolumn{2}{|l|}{$\mathrm{N}_{\mathrm{Jt}-1}$} & $0.0008(0.0004)$ & $0.0007(0.0004)$ & $\mathbf{0 . 0 0 3 2}(0.0004)^{* * *}$ & $\mathbf{0 . 0 0 3 1}(0.0005)^{* * *}$ \\
\hline \multicolumn{2}{|l|}{$\operatorname{Ln} \operatorname{GDP}_{\mathrm{t}-1}$} & $\mathbf{- 0 . 2 6 2 0}(0.018)^{* * *}$ & $\mathbf{- 0 . 2 8 0 4}(0.017)^{* * *}$ & $\mathbf{- 0 . 1 2 2 0}(0.017)^{* * *}$ & $\mathbf{- 0 . 1 3 3 0}(0.0170)^{* * *}$ \\
\hline \multicolumn{2}{|l|}{ Ln Importt-1 } & $-0.6060(10.432)$ & $-0.8741(41.961)$ & $-3.1288(1555182.18)$ & $-3.1138(1363608.163)$ \\
\hline \multicolumn{2}{|l|}{ China } & $1.4076(0.109)^{* * *}$ & $0.9038(0.101)^{* * *}$ & $1.6920(0.103)^{* * *}$ & $\mathbf{1 . 0 7 9 7}(0.111)^{* * *}$ \\
\hline \multicolumn{2}{|l|}{ Morocco } & $0.1939(0.134)$ & $0.3446(0.111)^{* *}$ & $0.4074(0.124)^{* *}$ & $0.4899(0.115)^{* * *}$ \\
\hline \multicolumn{2}{|l|}{ UnitedStates } & $1.4974(0.103)^{* * *}$ & $1.2567(0.100)^{* * *}$ & $1.7347(0.106)^{* * *}$ & $1.3659(0.111)^{* * *}$ \\
\hline \multicolumn{2}{|l|}{ Turkey } & $1.5814(0.112)^{* * *}$ & $0.9969(0.107)^{* * *}$ & $1.5764(0.108)^{* * *}$ & $0.9355(0.119)^{* * *}$ \\
\hline \multicolumn{2}{|l|}{ Thailand } & $1.1618(0.105)^{* * *}$ & $0.9713(0.0918)^{* * *}$ & $1.3936(0.095)^{* * *}$ & $1.1495(0.097)^{* * *}$ \\
\hline \multicolumn{2}{|l|}{ Brazil } & $\mathbf{0 . 8 7 4 3}(0.102)^{* * *}$ & $0.5966(0.0979)^{* * *}$ & $1.2153(0.100)^{* * *}$ & $0.8520(0.105)^{* * *}$ \\
\hline \multicolumn{2}{|l|}{ Argentina } & $\mathbf{0 . 6 1 6 0}(0.117)^{* * *}$ & $\mathbf{0 . 4 1 3 0}(0.106)^{* * *}$ & $\mathbf{0 . 7 9 2 3}(0.110)^{* * *}$ & $\mathbf{0 . 5 5 2 0}(0.114)^{* * *}$ \\
\hline \multicolumn{2}{|l|}{ Ukraine } & $-1.175(0.225)^{* * *}$ & $\mathbf{- 0 . 9 5 4 5}(0.181)^{* * *}$ & $\mathbf{- 0 . 9 1 2 4}(0.214)^{* * *}$ & $\mathbf{- 0 . 7 3 3 0}(0.186)^{* * *}$ \\
\hline \multicolumn{2}{|l|}{ Vietnam } & $\mathbf{0 . 7 0 9 3}(0.119)^{* * *}$ & $\mathbf{0 . 4 3 8 4}(0.111)^{* * *}$ & $\mathbf{0 . 9 3 2 6}(0.105)^{* * *}$ & $0.7142(0.107)^{* * *}$ \\
\hline \multicolumn{2}{|l|}{ Egypt } & $0.0274(0.132)$ & $-0.0736(0.120)$ & $0.3436(0.124)^{* *}$ & $0.1826(0.125)$ \\
\hline \multicolumn{6}{|l|}{$\mathbf{N}_{\mathrm{ijt} t-1}$} \\
\hline & China & $\mathbf{- 0 . 4 8 3}(0.058)^{* * *}$ & & $\mathbf{- 0 . 8 0 2 0}(0.033)^{* * *}$ & \\
\hline & Morocco & $0.1182(0.160)$ & & $0.0822(0.119)$ & \\
\hline & USA & $\mathbf{- 0 . 2 4 9 6}(0.08)^{* *}$ & & $\mathbf{- 0 . 5 7 4 5}(0.038)^{* * *}$ & \\
\hline & Turkey & $\mathbf{- 0 . 4 9 2}(0.056)^{* * *}$ & & $\mathbf{- 0 . 7 7 5 3}(0.031)^{* * *}$ & \\
\hline & Brazil & $\mathbf{- 0 . 2 8 3}(0.079)^{* * *}$ & & $\mathbf{- 0 . 5 8 8 2}\left(0.048^{* * *}\right.$ & \\
\hline & Argentina & $-0.2093(0.114)$ & & $\mathbf{- 0 . 4 0 2 7}(0.049)^{* * *}$ & \\
\hline & Thailand & $\mathbf{- 0 . 3 3 0}(0.083)^{* * *}$ & & $\mathbf{- 0 . 5 3 5 2}(0.054)^{* * *}$ & \\
\hline & Vietnam & $\mathbf{- 0 . 5 5 8}(0.084)^{* * *}$ & & $\mathbf{- 0 . 8 0 0 4}(0.054)^{* * *}$ & \\
\hline & Ukraine & $1.8046(0.623)^{* *}$ & & $\mathbf{2 . 0 3 0 9}(0.374)^{* * *}$ & \\
\hline & Egypt & $-0.1443(0.128)$ & & $\mathbf{- 0 . 3 3 9 7}(0.097)^{* * *}$ & \\
\hline
\end{tabular}


Chapter 3. Sanitary and Phytosanitary measures in agri-food imports from the European Union: Reputation effects over time

\begin{tabular}{|c|c|c|c|}
\hline \multicolumn{4}{|l|}{$\mathbf{N}_{\mathrm{ijt}-2}$} \\
\hline & China & $\mathbf{- 0 . 4 6 0}(0.065)^{* * *}$ & $\mathbf{- 0 . 8 2 3 3}(0.038)^{* * *}$ \\
\hline & Morocco & $-0.3067(0.186)$ & $\mathbf{- 0 . 4 1 0 8}(0.1568)^{* *}$ \\
\hline & USA & $\mathbf{- 0 . 6 5 1}(0.073)^{* * *}$ & $\mathbf{- 1 . 0 3 9 3}(0.049)^{* * *}$ \\
\hline & Turkey & $\mathbf{- 0 . 5 6 9}(0.059)^{* * *}$ & $\mathbf{- 0 . 9 7 6 7}(0.043)^{* * *}$ \\
\hline & Brazil & $\mathbf{- 0 . 4 7 7}(0.093)^{* * *}$ & $\mathbf{- 0 . 8 1 6 5}(0.067)^{* * *}$ \\
\hline & Argentina & $\mathbf{- 0 . 2 9 3 3}(0.115)^{*}$ & $\mathbf{- 0 . 6 0 2 2}(0.067)^{* * *}$ \\
\hline & Thailand & $\mathbf{- 0 . 2 7 5 0}(0.090)^{* *}$ & $\mathbf{- 0 . 5 7 9 9}(0.061)^{* * *}$ \\
\hline & Vietnam & $\mathbf{- 0 . 4 4 7}(0.077)^{* * *}$ & $\mathbf{- 0 . 8 2 5 6}(0.057)^{* * *}$ \\
\hline & Ukraine & $-1.1198(0.568)^{*}$ & $\mathbf{- 1 . 6 4 8 9}(0.693)^{*}$ \\
\hline & Egypt & $-0.2624(0.158)$ & $\mathbf{- 0 . 4 7 9 3}(0.110)^{* * *}$ \\
\hline \multicolumn{4}{|l|}{$\mathbf{N}_{\mathrm{ijt}-3}$} \\
\hline & China & $\mathbf{- 0 . 1 8 9 7}(0.063)^{* *}$ & $\mathbf{- 0 . 4 9 1 3}(0.037)^{* * *}$ \\
\hline & Morocco & $\mathbf{0 . 3 6 5 9}(0.1762)^{*}$ & $0.2208(0.170)$ \\
\hline & USA & $\mathbf{- 0 . 1 7 3 3}(0.069)^{*}$ & $\mathbf{- 0 . 4 8 5 8}(0.042)^{* * *}$ \\
\hline & Turkey & $-\mathbf{0 . 2 7 6 3}(0.05)^{* * *}$ & $\mathbf{- 0 . 5 8 4 4}(0.038)^{* * *}$ \\
\hline & Brazil & $\mathbf{- 0 . 2 0 8 3}(0.080)^{* *}$ & $\mathbf{- 0 . 5 1 5 1}(0.055)^{* * *}$ \\
\hline & Argentina & $\mathbf{- 0 . 3 3 9 2}(0.1361)^{*}$ & $\mathbf{- 0 . 4 4 7 4}(0.054)^{* * *}$ \\
\hline & Thailand & $-0.1052(0.100)$ & $\mathbf{- 0 . 2 4 6 7}(0.058)^{* * *}$ \\
\hline & Vietnam & $0.0826(0.124)$ & $\mathbf{0 . 1 8 8 0}(0.059)^{* *}$ \\
\hline & Ukraine & $1.6671(1.040)$ & 1.7599 (1.077) \\
\hline & Egypt & $-0.0428(0.140)$ & $\mathbf{- 0 . 2 3 6 9}(0.107)^{*}$ \\
\hline
\end{tabular}

${ }^{* * *} \mathrm{p}<0.001,{ }^{* *} \mathrm{p}<0.01,{ }^{*} \mathrm{p}<0.05$

Source: Authors' calculations

It should be noted that the country of origin per capita GDP is also significant since, as expected, the less is the per capita GDP, the higher is the probability of notifications. Another point to remark is that the value of previous years' imports is not significant in determining current year notifications. The effect of past import surges is therefore not relevant in this case.

As regards country fixed effects, in the most cases there is a higher propensity to receive notifications in the 10 most notified countries compared with the 29-country reference group. Only for Egypt the variable is not statistically significant, indicating a similar behaviour as for the reference group. Furthermore, we may note that Morocco's dummy variable is not significant in the ZINB1 model; and Ukraine shows less propensity, according to the negative significant coefficient in the four models. As far as the remaining countries are 
Chapter 3. Sanitary and Phytosanitary measures in agri-food imports from the European Union: Reputation effects over time

concerned, Turkey in the ZINB1 and the US in the other three models have the highest coefficients.

Turning to the interactions between the country fixed effects and the product reputations, in most cases the coefficients are significant. Their magnitude is usually less in the more efficient ZINB1 than in the NB1. We have used these interactions to provide a comprehensive view of the influence of past notifications on current notifications for the topten countries. Based on the ZINB1 results, we calculated the total effect of the three product notifications on the current number of notifications. To this end, we added the coefficients of the interactions with each country to the respective coefficients of the product reputation effects. These calculations are depicted in Figure 5.

Figure 5. Comparison of the reputation effects between the top-ten notified countries and the reference group

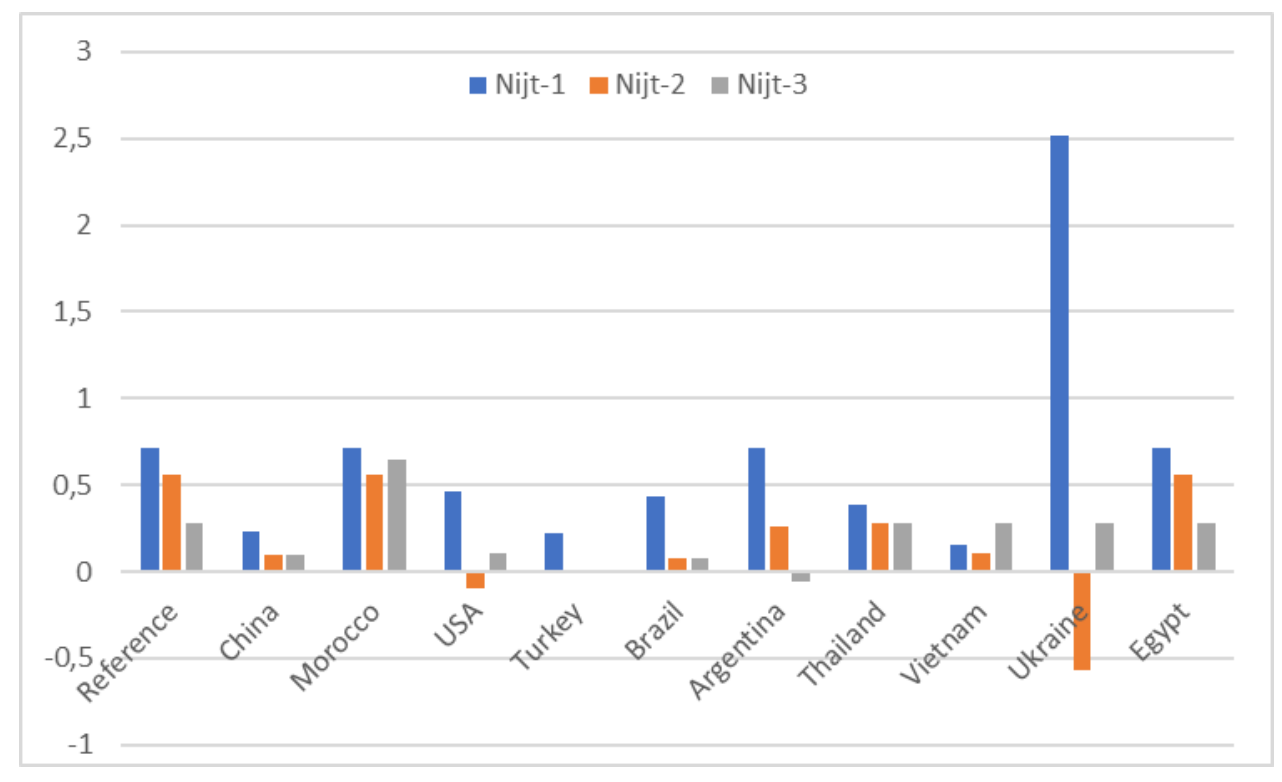

Source: Authors' calculations

We identified two groups of countries, depending on the evolution of the reputation effects and the long-term reputation. The first group is composed of China, the US, Turkey, Brazil and Argentina. Clearly, the reputation effects are diminishing over time and the effect of long-term reputation is less than for the reference group. This may indicate an effective effort by these countries to fix SPS problems detected in their exports to the EU.

Contrariwise, a second group of exporters, comprising Morocco, Thailand, Vietnam, Ukraine and Egypt, presents long-term reputation effects that are greater or equal to those for 
Chapter 3. Sanitary and Phytosanitary measures in agri-food imports from the European Union: Reputation effects over time

the reference group. Furthermore, the reputation effects do not show a decreasing path from the short to the long term, with the exception of Egypt. These countries are therefore performing worse than the previous group both in terms of long-run reputation and in terms of an effective reduction over time. This may indicate that the management of SPS measures in their exports to the EU is a challenge for them.

\subsection{Conclusions}

Our study aimed to investigate how past notifications can affect the application of SPS measures to EU imports of agri-food products. This aim is in line with an emerging trend in literature on the implementation of SPS measures. The underlying rationale is that past notifications can be relevant in determining which product, sector or country of origin is subject to checks: Border inspectors can be expected to target products that have had problems in the past or countries with a high probability of having problems to export certain products identified as sensitive in previous inspections. Our approach is based on the fact that EU import notifications are explained by three types of reputation effects, namely product, sector and country reputation. Besides, we checked for the effect of the previous year import value and per capita GDP of exporting countries. Furthermore, this paper raises the question of the effect of the evolution of reputation over time. To this end, we checked whether current notifications are affected by the previous year's notifications as well as by the second and third preceding years' notifications.

We used the RASFF database of EU notifications, in line with a number of recent research studies on trade issues. Three major problems were found in building the database: (1) the conversion of all recorded notifications from verbal form to HS code (2) the overdispersion in the data and (3) the excess of zeros in observations. Methodologically, and in order to take into account these features of the dataset, a word recognition algorithm was developed, and two count models were used to estimate these relationships.

Our findings support previous evidence found by Jouanjean et al. (2015) for the US, as well as by Garcia et al. (2015) and Taghouti et al. (2015), suggesting that EU SPS border controls are affected by reputation. As regards the evolution of reputation over time, our empirical results suggest that the number of EU notifications in the current year is affected firstly by the product's own reputation, with a relatively stronger effect in the case of onelagged-year notifications in comparison with two or three lagged years. 
Chapter 3. Sanitary and Phytosanitary measures in agri-food imports from the European Union: Reputation effects over time

After the product reputations, the sector reputation plays a smaller explanatory role, indicating a certain cross-attribution of reputation among similar products. Conversely, however, country reputation does not affect the number of current notifications or only does so very slightly. Altogether, this indicates that cross-attribution does not impact all the exports from the same country but tends to be limited to similar products.

Similarly, notifications are not affected by previous import values, thus countering the hypothesis of possible protectionist behavior after an import surge. However, the number of notifications varies negatively with the per capita GDP of the exporter, suggesting that a country's development level is a key determinant of the integration of agro-exporting enterprises in the global value chains in terms of complying with European product safety standards.

In most of the exporter countries under consideration, two different patterns were detected. For some countries, product reputation effects diminish consistently over time, which points to effective efforts on the part of these countries to fix the SPS problems notified previously. As a result, the long-term effect of a notification is very small or even absent. On the contrary, for another group of countries, a three-years-ago notification has detrimental effects on current SPS compliance. This is probably indicative that the efforts undertaken to fulfill SPS rules have not been sufficient and exports are still burdened by past (bad) performance. More rigorous public policies with pre-export facilities and controls could reverse this trend.

Some implications can be extracted from the results of this study as well as from similar findings in previous literature. First, the product reputation effect has been demonstrated to be a solid element framing SPS compliance in the agri-food imports of the two main agri-food world importers. Checking whether product reputation matters at other major importers' borders can be a relevant research area. Investigating the evolution of reputation effects for different countries in other geographical areas can also help to contrast current results.

Secondly, this paper has shown that long-term reputation also matters and, more specifically, that some countries have been able to soften its impact while others have not. Therefore, analyzing the measures implemented in different instances can be a fruitful exercise, not only in terms of pure academic research but also as a basis for good policymaking. In this vein, Soriano and Garrido (2015) highlight the trade-enhancing effects of public-private investments in infrastructure in developing countries. Some pre-export 
Chapter 3. Sanitary and Phytosanitary measures in agri-food imports from the European Union: Reputation effects over time

facilities such as warehouses, terminals, roads etc. are part of this infrastructure and can enhance compliance with SPS rules.

Thirdly, it should be noted that, in dealing with the different types of notifications, our study has not used a causality framework. The shift in the RASFF data from information to border rejections may suggest a tightening of the SPS rules at the EU borders that deserves further attention. Finally, our study provides an opportunity to stress that the RASSF database can be a rich source of detailed information on agri-food trade. Focusing on the reasons for notifications or further investigating the most notified products can provide other valuable insights into the implementation of SPS measures at the EU borders. 
Chapter 3. Sanitary and Phytosanitary measures in agri-food imports from the European Union: Reputation effects over time

\section{References}

Bagwell, K. \& Staiger, R. (2001). Domestic policies, national sovereignty, and international economic institutions. The Quarterly Journal of Economics, 116(2), 519-562. http://dx.doi.org/10.1162/00335530151144096

Burger, M., van Oort, F., \& Linders, G. (2009). On the specification of the gravity model of trade: Zeros, excess zeros and zero-inflated estimation. Spatial Economic Analysis, 4(2), 167-190. http://dx.doi.org/10.1080/17421770902834327

Cadot, O., Malouche, M., \& Sáez, S. (2012). Streamlining non-tariff measures: A toolkit for policy makers. World Bank Publications. https://openknowledge.worldbank.org/bitstream/handle/10986/6019/683590PUB0EPI 007902B009780821395103.pdf?sequence $=1$

Cameron, A. \& Trivedi, P. (2010). Microeconometrics using Stata. College Station, Tex.: Stata.

Cameron, A. \& Trivedi, P. (2013). Regression analysis of count data (2nd edition). Cambridge, UK: Cambridge University Press.

Commission Regulation (EU) No 16/2011 of 10 January 2011 laying down implementing measures for the Rapid Alert System for Food and Feed Text with EEA relevance. Available at http://eur-lex.europa.eu/legalcontent/EN/TXT/?uri=CELEX\%3A32011R0016.

Copeland, B. (1990). Strategic interaction among nations: Negotiable and non-negotiable trade barriers. The Canadian Journal Of Economics, 23(1), 84. http://dx.doi.org/10.2307/135521

Dal Bianco, A., Boatto, V., Caracciolo, F., \& Santeramo, F. (2015). Tariffs and non-tariff frictions in the world wine trade. European Review Of Agricultural Economics, 43(1), 31-57. http://dx.doi.org/10.1093/erae/jbv008

Disdier, A., Fontagné, L., \& Cadot, O. (2015). North-South standards harmonization and international trade. The World Bank Economic Review, 29(2), 327-352. http://dx.doi.org/10.1093/wber/lht039

Ederington, J. (2001). International coordination of trade and domestic policies. American Economic Review, 91(5), 1580-1593. http://dx.doi.org/10.1257/aer.91.5.1580 
Chapter 3. Sanitary and Phytosanitary measures in agri-food imports from the European Union: Reputation effects over time

Fontagné, L., Mimouni, M., \& Pasteels, J. (2005). Estimating the impact of environmental SPS and TBT on international trade. Integration And Trade Journal, 22(9), 7-37.

García-Álvarez-Coque, J. M., Tudela-Marco, L. \& Martí-Selva, L. (2015). Investigating differences in safety border notifications on fruit and vegetables imports by selected EU member states. International Conference of Agricultural Economists. Milan.

Grazia, C., Hammoudi, A., \& Malorgio, G. (2009). Regolamentazione della qualità sanitaria degli alimenti e accesso dei paesi della riva Sud del Mediterraneo ai mercati europei: un'analisi empirica. In Cambiamenti nel sistema alimentare. Nuovi problemi, strategie, politiche. XLVI Convegno Sidea, Piacenza, 16-19 settembre 2009 (1st ed.).

Greene, W. (1994). Accounting for excess zeros and sample selection in Poisson and negative binomial regression models. New York: New York University, Leonard N. Stern School of Business.

Henson, S. \& Jaffee, S. (2008). Understanding developing country strategic responses to the enhancement of food safety standards. The World Economy, 31(4), 548-568. http://dx.doi.org/10.1111/j.1467-9701.2007.01034.x

Jaud, M., Cadot, O., \& Suwa-Eisenmann, A. (2013). Do food scares explain supplier concentration? An analysis of EU agri-food imports. European Review Of Agricultural Economics, 40(5), 873-890. http://dx.doi.org/10.1093/erae/jbs038

Jouanjean, M., Maur, J., \& Shepherd, B. (2012). Reputation Matters: Spillover Effects in the Enforcement of US SPS Measures. Non-Tariff Measures. In A Fresh Look at Trade Policy's New Frontier (1st ed.). NW, Washington: USA: The International Bank for Reconstruction and Development. The World Bank.

Jouanjean, M., Maur, J., \& Shepherd, B. (2015). Reputation matters: Spillover effects for developing countries in the enforcement of US food safety measures. Food Policy, 55, 81-91. http://dx.doi.org/10.1016/j.foodpol.2015.06.001

Kallummal, M., Gupta, A., \& Varma, P. (2013). Exports of agricultural products from SouthAsia and impact of SPS measures: A case study of European Rapid Alert System for Food and Feed (RASFF). Journal Of Economic Policy \& Research, 8(2), 41-75.

Kleter, G., Prandini, A., Filippi, L., \& Marvin, H. (2009). Identification of potentially emerging food safety issues by analysis of reports published by the European Community's Rapid Alert System for Food and Feed (RASFF) during a four-year period. Food And Chemical Toxicology, 47(5), 932-950. http://dx.doi.org/10.1016/j.fct.2007.12.022 
Chapter 3. Sanitary and Phytosanitary measures in agri-food imports from the European Union: Reputation effects over time

Lambert, D. (1992). Zero-Inflated Poisson Regression, with an Application to Defects in Manufacturing. Technometrics, 34(1), 1. http://dx.doi.org/10.2307/1269547

MAHE, L. (1997). Environment and quality standards in the WTO: New protectionism in agricultural trade? A European perspective. European Review Of Agricultural Economics, 24(3-4), 480-503. http://dx.doi.org/10.1093/erae/24.3-4.480

RASFF,. (2013). The Rapid Alert System for Food and Feed, 2013 Annual Report. Retrieved from https://ec.europa.eu/food/sites/food/files/safety/docs/rasff annual report 2013.pdf

Soriano, B. \& Garrido, A. (2015). The role of private sector in development: The relation between public-private investment in infrastructure and agricultural exports in developing countries. Economia Agraria Y Recursos Naturales, 15(2), 93-117. http://dx.doi.org/10.7201/earn.2015.02.05

Taghouti, I., Martinez-Gomez, V., \& Garcia-Alvarez-Coque, J. (2015). Exploring EU food safety notifications on agro-food imports: are Mediterranean Partner Countries discriminated?. International Journal Of Food And Agricultural Economics, 3(2), 1529.

United Nations Conference on Trade and Development UNCTAD. (2015). International classification of Non-Tariff Measures, 2012 Version. United Nations. Retrieved from http://unctad.org/en/PublicationsLibrary/ditctab20122_en.pdf

Vuong, Q. (1989). Likelihood ratio tests for model selection and non-nested hypotheses. Econometrica, 57(2), 307. http://dx.doi.org/10.2307/1912557

Yue, C. \& Beghin, J. (2009). Tariff equivalent and forgone trade effects of prohibitive technical barriers to trade. American Journal Of Agricultural Economics, 91(4), 930941. http://dx.doi.org/10.1111/j.1467-8276.2009.01306.x

Zeileis, A., Kleiber, C., \& Jackman, S. (2008). Regression models for count data in R. Journal Of Statistical Software, 27(8), 1-25. http://dx.doi.org/10.18637/jss.v027.i08 
Implications of changing aflatoxin standards for EU border controls on nut imports 
Chapter 4. Implications of changing aflatoxin standards for EU border controls on nut imports

\section{Co-author letter}

UNIVERSITAT

POLITÉCNICA

DE VALÈNCIA

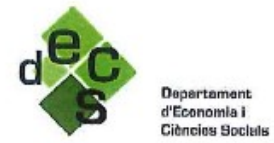

Valencia, 3 february2017

Mr. Jose Maria Garcia-Alvarez-Coque Co-author of the publication: Co-author of the publication: Implications of changing aflatoxin standards for EU border controls on nut imports, submitted to the " XV EAAE Congress 2017 ", Declares that he agrees with the presentation by the doctoral candidate, Ibtissem Taghouti, of this publication as part of the doctoral thesis; additionally expresses his renounce to the use of this work as part of other doctoral thesis.
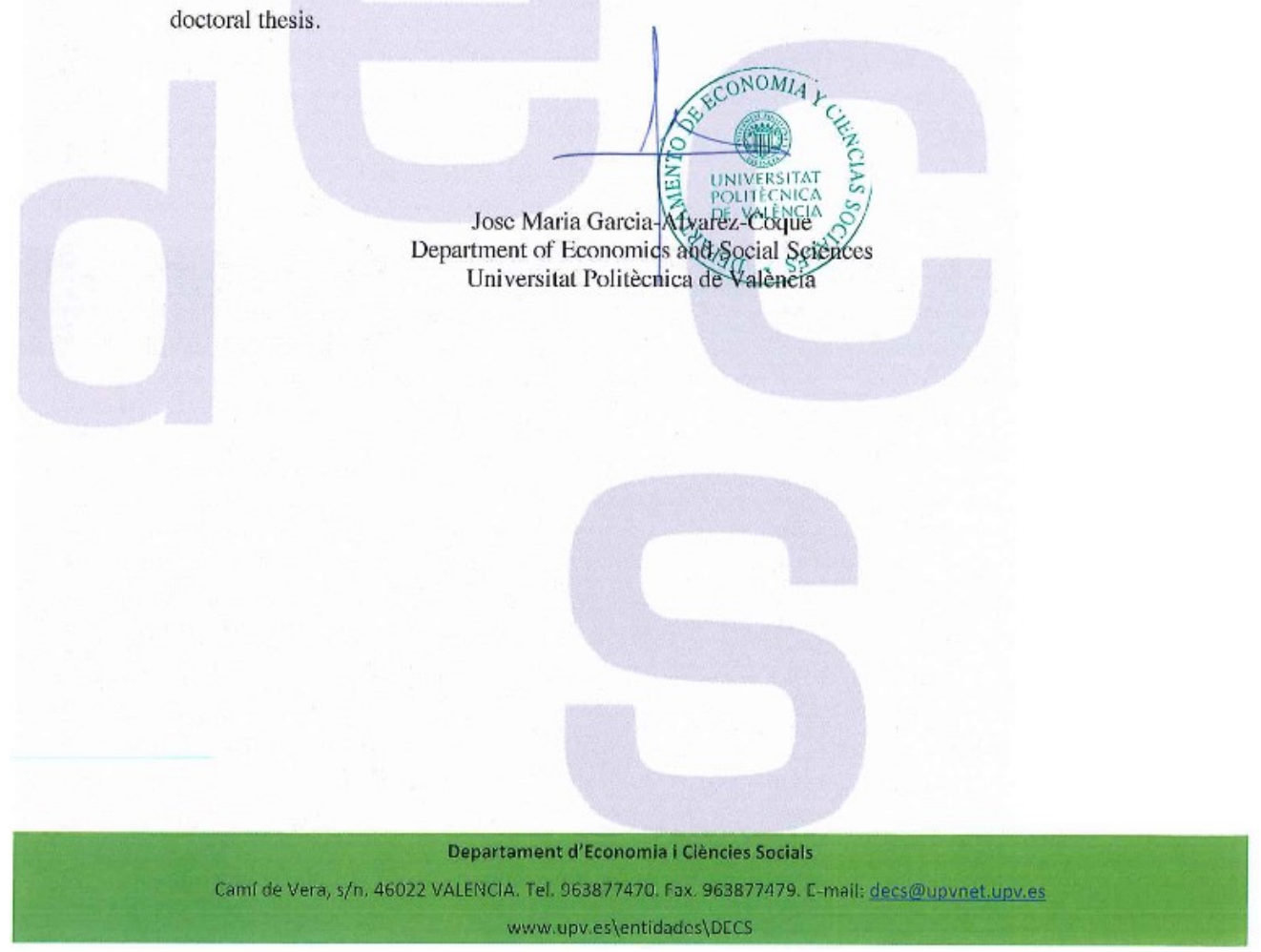

Source: Department of Economics and Social Sciences; Dr. Jose Maria Garcia-Alvarez-Coque 
Chapter 4. Implications of changing aflatoxin standards for EU border controls on nut imports

\section{Co-author letter}

UNIVERSITAT

POLITECHICA

DE VALĖNCIA

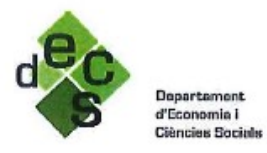

Valencia, 3 february2017

Mr. Victor Martinez-Gomez Co-author of the publication: Implications of changing aflatoxin standards for EU border controls on nut imports, submitted to the " XV E $\wedge \mathrm{E}$ Congress 2017 ", Declares that he agrees with the presentation by the doctoral candidate, Ibtissem Taghouti, of this publication as part of the doctoral thesis; additionally expresses his renounce to the use of this work as part of other doctoral thesis.

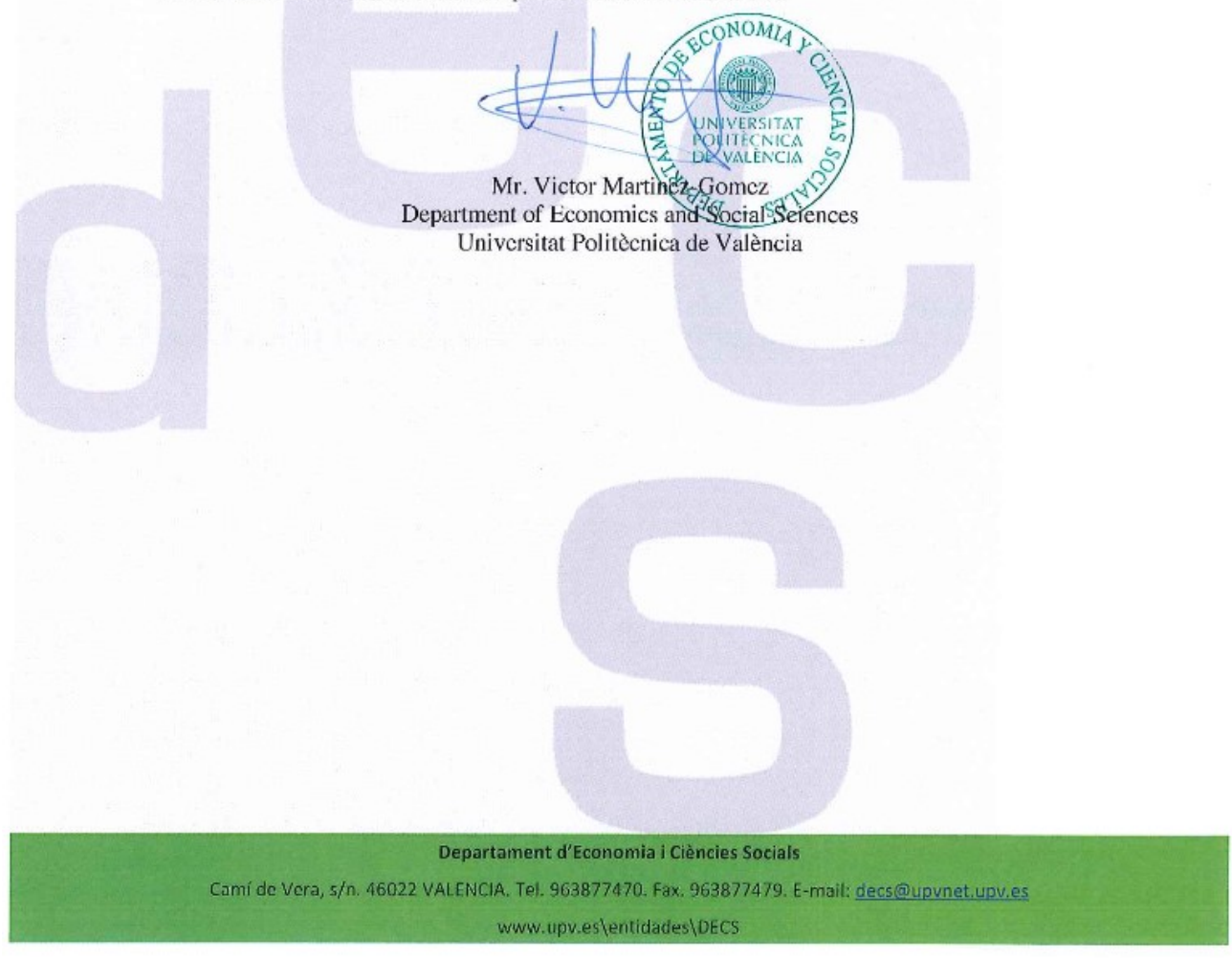

Source: Department of Economics and Social Sciences; Dr. Victor Martinez-Gomez 


\title{
Implication of changing aflatoxin standards for $\mathbf{E U}$ border controls on nut imports
}

\author{
Ibtissem Taghouti ${ }^{1}$ \\ José Maria Garcia-Alvarez-Coque ${ }^{1}$ \\ Victor Martinez-Gomez ${ }^{1}$ \\ ${ }^{1}$ Department of Economics and Social Sciences; \\ Group of International Economics and Development; \\ UPV-UniversitatPolitècnica de València, Spain
}

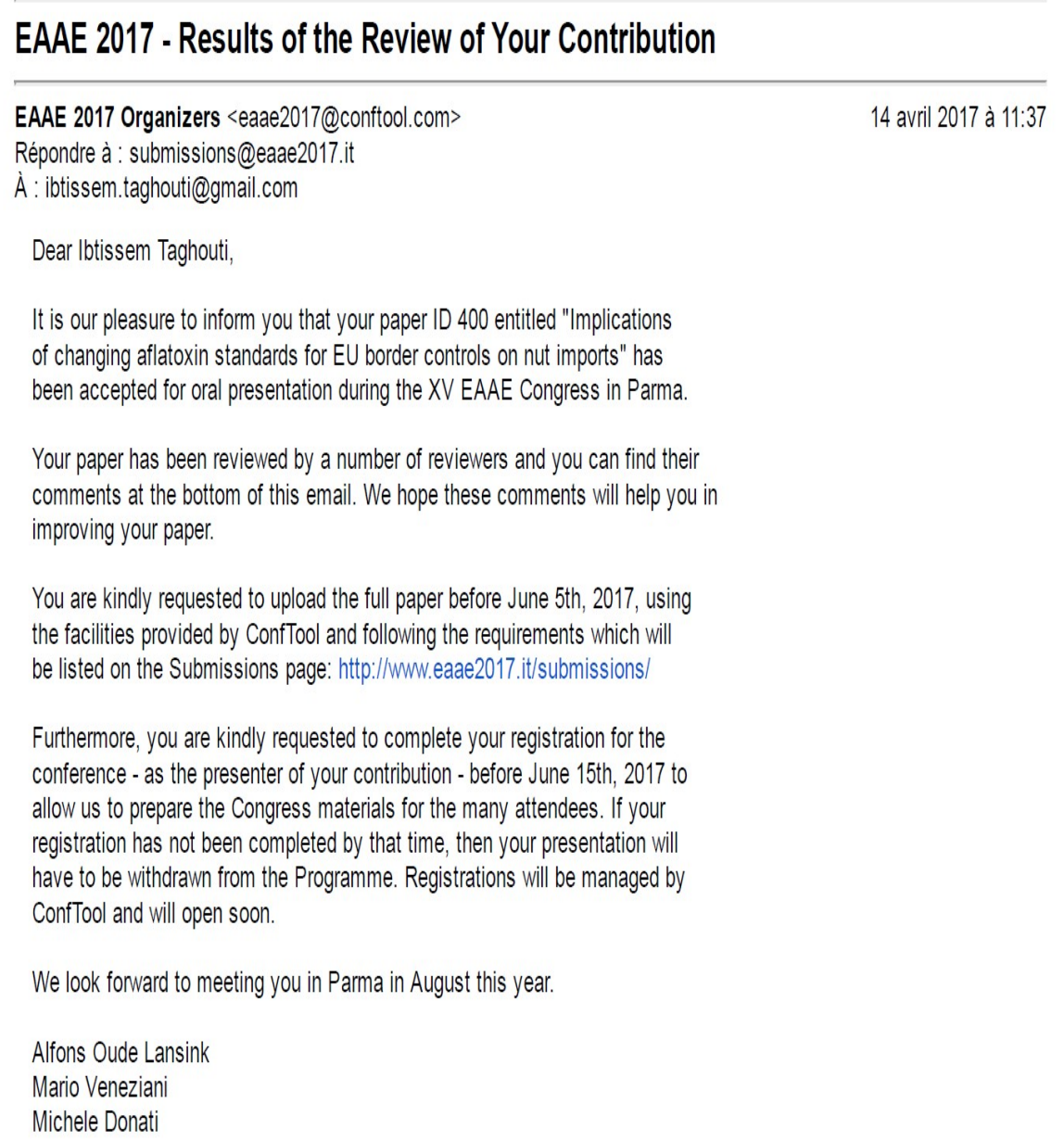




\title{
Chapter 4. Implications of changing aflatoxin standards for $\mathbf{E U}$ border controls on nut imports
}

\begin{abstract}
Food safety concerns regarding the risk of Aflatoxin (AF) contamination have been growing in many regions of the world in general and in Europe in particular. Tree nuts and Peanuts are the main source of human dietary AF. In order to protect consumers from health risks, the EU has implemented stricter standards regarding the maximum acceptable AF levels in food commodities. The AF standards have been subjected to several changes in the EU, involving changes in the number of AF notifications as measured by the RASFF system. The objective of the present study aims at analyzing the behavior of the EU in controlling AF contamination with respect to tree nuts and groundnuts. To conduct this analysis, we have used a count data model, based on political economy considerations, past alerts and path dependence effects. Policy changes, including harmonization of AF standards and their further relaxing are estimated to have significant impact on the frequency of border controls.
\end{abstract}

Key words: AF, Market access, Non-tariff measures, tree nuts.

\subsection{Introduction}

While traditional trade barriers in agri-food trade, such as tariffs, start to be insignificant, technical and regulatory barriers are increasingly subject to many discussions. This includes mainly debates over the adequate levels of sanitary and phyto-sanitary standards (Wilson, 2000). Public debates and concerns about the health risks of food and suitable sanitary standards have been rising (Pinstrup-Andersen, 2000) and have been particularly pronounced in Europe (Nielson and Anderson; 2000). The analysis of the trade impacts of non-tariff measures has been frequent, mainly through gravity-type models (Ferro et al., 2015). However, the explanation of the frequency of standard-like measures is still an emerging area, which has until now being treated through political-economy approaches, reviewed by Swinnen (2010, 2016) and Beghin et al. (2015).

Few empirical analyses exist to identify the factors that influence the frequency of standard-like measures. In particular, this paper carries out an attempt to determine the factors 
Chapter 4. Implications of changing aflatoxin standards for EU border controls on nut imports

predicting the frequency of border controls related to a particular sanitary problem, Aflatoxins $(\mathrm{AF})$, in a particular group of products where this problem is relatively frequent: nuts. The estimated model will assess the impact of two major regulatory changes in the EU, which included the harmonization of AF standards, at the beginning of the century, and a later adjustment of the standard to converge with Codex provisions, after 2009. Therefore, we consider the impact on the enforcement of standard-like measures and their later partial lessening. For that, our model will introduce political economy considerations and will do it in a dynamic way by considering the path dependency on previous border controls. Path dependence in the implementation of border controls ('history matters') has been a notion considered in previous analysis of non-tariff measures in the US (Jouanjean et al., 2015) and the EU (Taghouti et al., 2015, 2016; Tudela et al., 2016).

Determining the frequency of non-tariff measures is of interest for nut exporters to the EU in order to avoid export losses and guarantee market access ${ }^{17}$. AF are, in fact, a source of significant economic losses for nut exporters to the EU (Wu, 2004; Diaz Rios and Jaffe, 2008; Wu and Guglu, 2012). These issues led Kofi Annan, former United Nations (UN)'s Secretary General to underline the magnitude of the problem with respect to the definition of adequate AF standards worldwide. AF contamination of agro-food staples and nuts in particular can directly increase the rejection probability in frontiers and reduce the market value.

There are several reasons behind trade disagreements regarding AF standards' setting. First, AF contamination is recognized as an unavoidable menace. Indeed, Codex has declared that contamination in nuts and grains could be caused mainly by environmental factors, such as weather and insect infestation, which makes its control difficult or impossible (Buzby , 2003). Second, AF standards are widely different through countries, which underline the absence of scientific norms in setting new standards. Finally, perceptions of health risks depend directly on the level of economic development of producing countries and the susceptibility of a product to contamination.

Edible nuts trade to the EU remains heavily dependent on restrictive controls of AF carried out by MS, which affect the economy of nuts producers. In EU, AF are commonly cited as a main reason for import 'notifications' in the RASFF database (RASFF, 2002, 2015). Outsuki et al. (2001) analyzed the impact of changing AF standards on the trade flows

\footnotetext{
${ }^{17}$ Nuts in this paper include almonds, groundnut, Brazil nuts, cashews, chestnuts, hazelnuts, macadamias, pecans, pine nuts, pistachios and walnuts.
} 
Chapter 4. Implications of changing aflatoxin standards for EU border controls on nut imports

of groundnuts products suggesting that a $10 \%$ tighter AF standard in the EU would decrease edible groundnut imports by $11 \%$. The present paper introduces a new method, based on political economy consideration, to assess recent regulatory changes.

Before 1998, the European members were using different standards for AF in foodstuffs. Then, the European Commission (EC) initiated a harmonization of maximum allowable level of AF in edible nuts and dried fruits. By 2003, the EU had imposed a harmonized AF standard in tree nuts, including pistachios, of a maximum residue level (MRL) of $4 \mu \mathrm{g} / \mathrm{kg}$. This initiative led to concern among nuts exporters about the new standards, which could alter the trade patterns. Many exporters to the EU emphasized that the new standard constituted an unjustifiable trade barriers and a violation of the Agreement on Sanitary and Phyto-sanitary Standards (WTO, G/SPS/R/14, 1999). Revised AF standards were suggested by the Codex and appeared more relaxed than the EU standards (Henson et al., 2000). Finally, the European Food Safety Agency (EFSA) adopted in 2009 a statement concluding that public health would not be adversely affected by increasing of the MRLs for AF total from $4 \mu \mathrm{g} / \mathrm{kg}$ to $10 \mu \mathrm{g} / \mathrm{kg}$ for tree nuts, which implied relaxing the previous standard.

The present paper makes use of the food notifications and alerts provided by the European Commission's Rapid Alert System for Food and Feed (RASFF) ${ }^{18}$. This database allows for a rapid exchange of information about measures taken in response to various risks detected in imported food and feed to the European Union. The number of RASFF notifications on AF actions taken by EU MS is considered here as a direct measure of NTMs. The RASFF has been used previously to analyze the impact of SPS measures on the agri-food trade. Based on EU imports, RASFF notifications were evaluated by Kleter et al. (2009) to present emerging trends in recent food safety problems. In addition, Jaud et al. (2013) used the same data source including notifications of 146 exporters to the EU in order to find out the geographical concentration of EU agri-food imports. Kallumal et al. (2013) explored the RASFF database to present the impact of EU food safety measures on trade flows between the south Asian countries and the European market.

In the next pages, after reviewing the main regulations on $\mathrm{AF}$ and their implementation on nuts by the EU, a conceptual framework will be proposed to model the

\footnotetext{
${ }^{18}$ See Taghouti et al. $(2015,2016)$ for detailed explanation on dataset extraction from the Rapid Alert System for Food and Feed (RASFF).
} 
Chapter 4. Implications of changing aflatoxin standards for EU border controls on nut imports

frequency of border notifications as measured by the RASFF database, and to estimate the impact of regulatory changes.

\subsection{Aflatoxins and nuts in the $\mathbf{E U}$}

The European market for edible nuts can be divided into two broad segments: the agro-food industry and the end-consumers. The majority of edible nuts in the EU are used by the food processing industry. All packaging and processing for edible nuts is done in the EU. Indeed, supermarkets and the food service sector dominate the sale in all European countries, with clear concerns about the safety conditions of the products. Although Europe produced only $8 \%$ of tree nut, it is the second largest consumer of tree nut in the world after North America and represents $25 \%$ of world consumption of tree nut in the world. In 2015, North America was the region with the highest production of tree nuts followed by Asia and the Middle East. Tree nut and peanut exports volumes are growing in last years. However, the high level of AF contamination in nuts and the important number of alerts and border rejection at the European frontiers threaten to disturb these positive trends.

Natural contamination of nuts with AF is unavoidable and causes a special challenge for nuts safety and quality. AF is a natural substance produced by fungi "Aspergillus flavus" and "Aspergillus parasiticus". Under favorable temperature and humidity conditions these fungi affect various foodstuffs, most commonly groundnuts, dried fruit, tree nuts, spices and a range of cereals (Strosnider et al., 2006). Contamination of these commodities by AF can occur at any stage of the value chain especially when storage and drying facilities are inappropriate. The most toxic and common $\mathrm{AF}$ is $\mathrm{B} 1$ and affects generally groundnuts and tree nuts, Brazil nuts, Pistachio nuts and walnuts (FAO-WHO, 1997). AF affect 4.5 billion persons in the world through chronic exposure watched in various forms as Cancer and death cases (US Centers for Disease Control and Prevention, 2004; Emmott, 2012). AF is considered a significant problem in developing countries, which can generate substantial economic consequences. Due to the strict AF standards, many countries will export their topquality foods and keep contaminated products domestically, exposing then their citizens to the risk of contamination by AF. On the other hand, there is controversy on the benefits for the EU of tightening the standards. Indeed, the Joint FAO/WHO Expert Committee on Food Additives (JECFA) analyzed the potential consumer health impact of AF for two levels: 10 parts per billion (ppb) and $20 \mathrm{ppb}$. The reduction of standards from $20 \mathrm{ppb}$ to $10 \mathrm{ppb}$ in 
Chapter 4. Implications of changing aflatoxin standards for EU border controls on nut imports

European MS was estimated to result in a drop of the population risk of about only two cancer deaths per year per billion people.

In 2002, the EU formally adopted a unified MRL policy on AF contaminants (European Communities, (2001, 2002)). In December 2006, the EU modified the harmonized maximum levels for certain contaminants in foodstuffs, but the policy regarding AF remained (European Communities, 2006). The harmonized EU AF standard was more stringent than the Codex Alimentarius, which contains the international standards recommended by the Food and Agriculture Organization (FAO) and World Health Organization (WHO). First, the EU policy targets specific AF compounds. Not only the EU policy sets an MRL for the total AF level as Codex does, it also imposes an MRL on AF B1, which is the most toxic compound in the AF family. Second, the EU MRLs are much lower than Codex. Indeed, the European authorities have been critical to rely on the 'precautionary behavior' and to drive policies providing a legitimate basis for regulation that restrict importing agri-food products. Nut exporters are widely affected by these regulations.

The EU officially amended AF maximum levels for tree nuts at the Standing Committee on the Food Chain and Animal Health meeting that took place on October 15th, 2009. Maximum levels for total AF for further processing (15 ppb) and ready-to-eat (10 ppb) almonds, hazelnuts and pistachios were accepted for EU implementation, aligned with the Codex maximum levels. The European control frequency at import also decreased for certain origins (Iranian pistachios and US almonds).

The regulatory changes are to a great extent reflected in the RASFF database. AF are found to be the hazard category with the highest number of notifications. In 2003, the RASFF registered a total of 695 notifications on AF in trading nuts. The number of notifications substantially grew after the EU harmonization and became more than three times as much as compared to 2002 (Figure 6). Iranian pistachios were the most notified product in that period. After 2009, notifications significantly decreased compared to the three previous years. This could be related to the change of legislation and the corresponding compliance of imported nuts. 
Chapter 4. Implications of changing aflatoxin standards for EU border controls on nut imports

Figure 6. AF notifications of nuts and nut products (2002-2015)

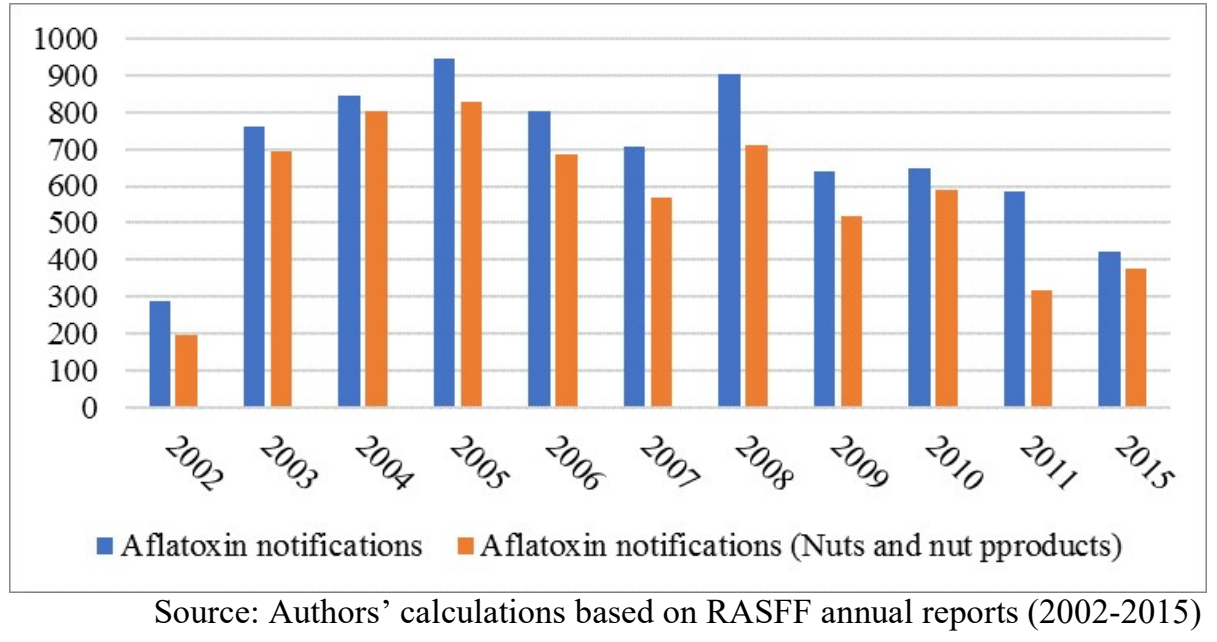

During the period of analysis covered in this work, the most notified products were pistachios, with 2972 notifications, followed by peanuts (2381 notifications), almonds (905), pecans (178) and Brazil nuts (119). Statistics show that over 37\% of notified nuts were rejected at the borders of the EU in the period 1998-2015. About $60 \%$ of total notifications were information notifications. Alerts represented only $4 \%$ of notified products but we consider them as an activator of further actions or controls. Figure 7 indicates an important dispersion and heterogeneity across exporting countries of nuts and groundnut to Europe. Iran and Turkey are the most notified countries receiving together half of notifications in the period 1998-2015. China accounts for 13\% of observations followed by United States (9\%), Argentina (6\%) and Brazil (5\%).

Figure 7. Percent of nuts and groundnut notifications by country ${ }^{19}$, (average 1998-2015)

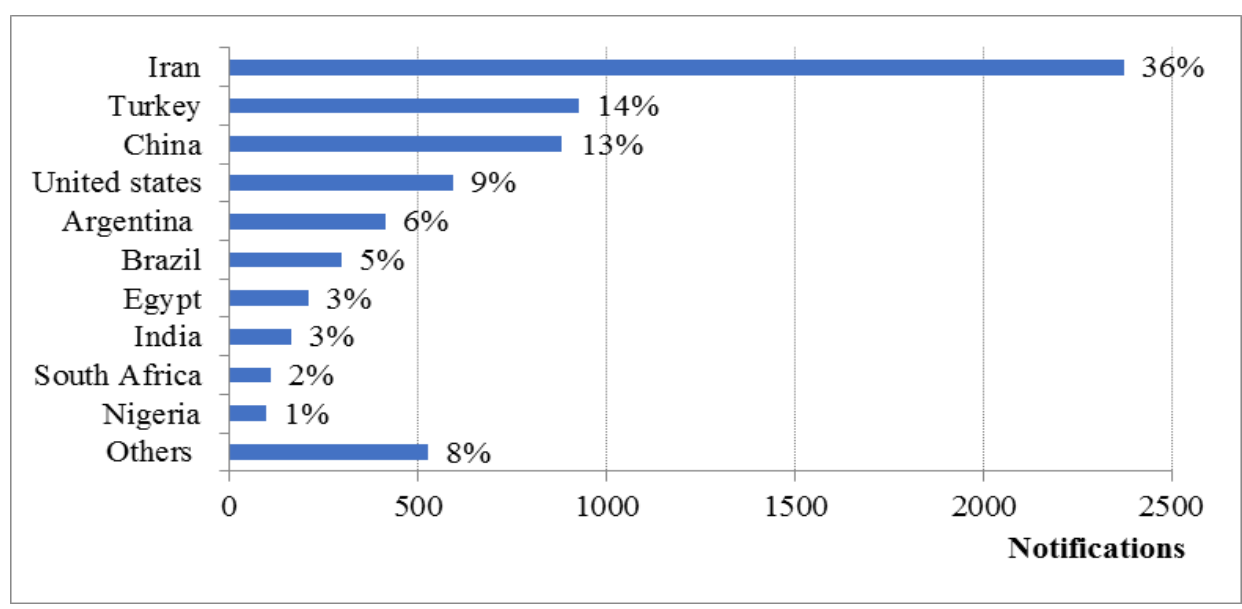

Source: Authors' calculations based on RASFF data

\footnotetext{
19 Top 10 notified countries
} 
Chapter 4. Implications of changing aflatoxin standards for EU border controls on nut imports

The European Union is the biggest importer of edible nuts in the world. Indeed, the largest European importers of edible nuts in terms of value are Germany, the Netherlands, Italy and Spain. These countries concentrated together 70\% of the European imports in 2015 . About $40 \%$ of European imports are coming from only two providers: the USA, providing mainly almonds and walnuts, and Turkey (hazelnuts and dried fruits as grapes and apricots) (Figure 8). In 2015, almonds have the highest value of imports with $41 \%$ share followed by hazelnuts (22\%), walnuts (14\%) and cashew nuts (9\%) (Trademap, 2016).

Figure 8. Main external suppliers of edible nuts of the EU in 2015 in thousands of euros

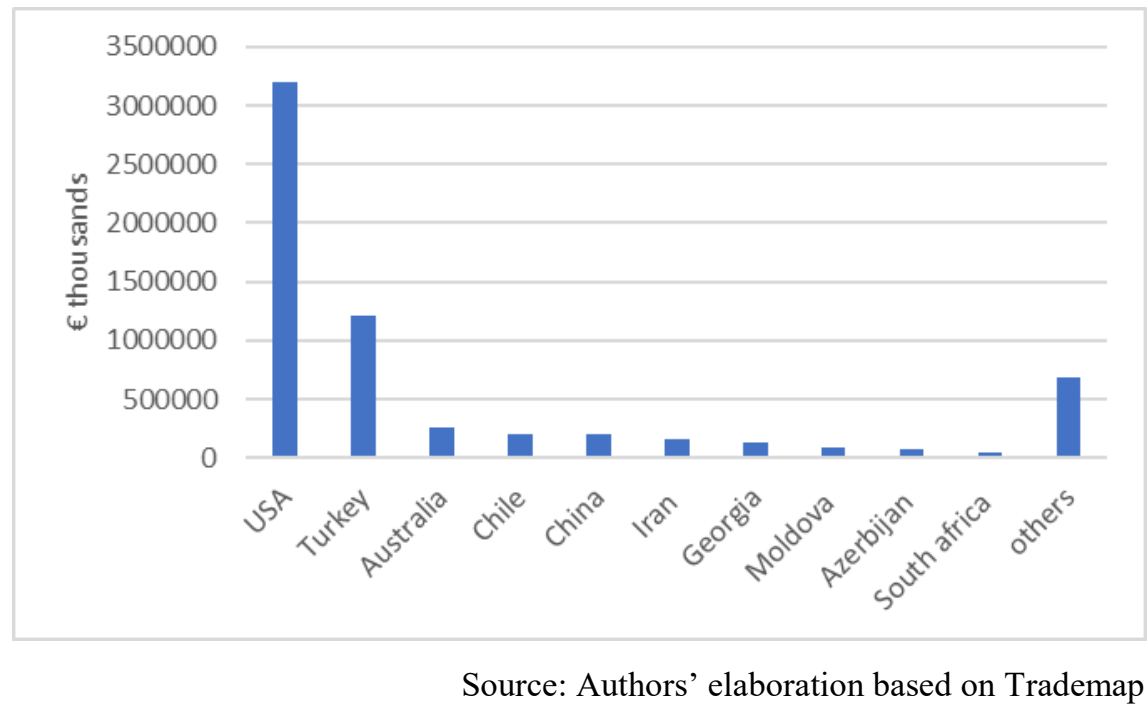

Given the limited number of studies that have used empirical data to estimate the effect of European AF standards on agri-food trade, we focus on RASFF notification as a measure of border controls. The present study focuses on the AF notifications of tree nut and peanuts for the period (1998-2015) built on 65 countries $^{20}$ and coded into HS6 product categories, generating an outcome variable defined as the notification count by HS6 code, country of origin and year. For the empirical analysis, we included trade data to consider

\footnotetext{
${ }^{20}$ Afghanistan, Albania, Argentina, Australia, Azerbaijan, Bangladesh, Benin, Bolivia, Bosnia and Herzegovina, Brazil, Bulgaria, Cameroon, Chile, China, Congo, Côte d'Ivoire, Croatia, Egypt, Faeroe Islands, Gambia, Georgia, Ghana, Hong Kong, India, Indonesia, Iran, Israel, Jordan, Kuwait, Kyrgyzstan, Lebanon, Madagascar, Malawi, Mauritius, Malaysia, Morocco, Mozambique, Namibia, Nicaragua, Nigeria, Pakistan, Paraguay, Philippines, Russia, Rwanda, San Marino, Senegal, Sierra Leone, Singapore, South Africa, Sri Lanka, Sudan, Syria, Taiwan, Tajikistan, Thailand, Togo, Tunisia, Turkey, Uganda, Ukraine, United states, Uzbekistan, Vietnam, Zambia.
} 
Chapter 4. Implications of changing aflatoxin standards for EU border controls on nut imports

annual bilateral trade volumes over the period 1998-2015. Our empirical framework concentrated only on notifications of $15 \mathrm{EU}$ member countries because the assumption of time invariant number of European MS can be extended for a long period.

\subsection{Conceptual framework}

The count of RASFF notifications indicates a measure of concern about 'a serious direct or indirect risk to human health'. However, the number of notifications can be related to a greater number of checks or the level of the applied standard, which can be related to practices, inspection styles and risk perception (May and Winter, 2000; Versluis, 2007). Moreover, political economy considerations may influence national authorities to take control measures and release RASFF notifications.

We propose a model to explain the frequency of border controls that monitor or prevent the presence of AF on EU imports of nuts. The model will be able to test, firstly, the influence of political and technical variables that affect the odds of a RASFF notification. Secondly, the model will be used to assess the impact of critical regulatory changes, in particular, the harmonization of the AF standards within the EU (2002) and the regulatory convergence with the Codex standards in 2009.

The theoretical framework can well depart from a political economy approach, which is based on the Grossman-Helpman model of political influence (1992), which in turn has given to the modelling of food standards (Swinnen and Vandemoortele, 2011) and has given raised to several applications to context different from the implementation of health standards on trade (Vigani and Olper, 2013). In our case the framework is modified to take into account, firstly, the capacity of exporting countries to meet the standards; and secondly, the pathdependence on previous decisions, so we include dynamicity in the model.

Dynamics the explanation of RASFF notifications can be included in the model by testing the hypothesis that the history of MS actions significantly influences present control measures so the follow-up of notifications issued in one year may affect the probability of future notifications. This may reflect a precautionary behavior in a MS related to risks that appeared in previous periods, or that further controls are needed to re-establish confidence before real product improvements have taken place to meet the standard requirements. Path dependence in food measures can be a sign of 'stickiness' in border checks or of the propensity of one MS to continue to control imports in subsequent periods after an initial risk 
Chapter 4. Implications of changing aflatoxin standards for EU border controls on nut imports

was detected (Baylis et al., 2009; Jouanjean et al., 2015). Likewise, persistence of control measures might express national perceptions on the loss of reputation that foreign products can suffer after a risk or food crisis emerges (Jouanjean, 2012; Taghouti et al., $(2015,2016)$ ). Such perceptions can be specific of the product concerned but are also dependent on the reputation or spillover effects involved when a significant number of notifications concern the origin of the product (exporting country's reputation). In short, in the context of the present paper, a notification in period ' $t$ ' is affected by decisions taken in the previous year.

The general approach assumes that public administration, in our case, the Commission and the national public services controlling food imports are willing to optimize producers and consumers welfare and consequently, enforce a standard and carry out the corresponding border controls. We can start from a welfare objective $\mathrm{W}$ for the public administration:

$$
W=\varphi\left(\omega_{s}, \omega_{c}, \chi_{j}\right)
$$

Where $\omega_{s}$ and $\omega_{c}$ are the producers and consumers' welfare, and $\chi_{j}$ is the capacity of the exporting countries $\mathrm{j}$ to comply with the standard. We assume that $\chi_{j}$ is influenced by the development level of the exporting countries and also by path dependence on previous RASFF notifications or country reputation that may force a country $\mathrm{j}$ to adjust its export strategy by reducing its export to the EU or by improving its quality control procedures. We can therefore assume that $\chi_{j}$ depends on $N_{\mathrm{jt}-1}$, where $N_{\mathrm{jt}-1}$ is the total number of RASFF notifications received by country $\mathrm{j}$ in period $\mathrm{t}-1$, including all nuts. As for the influence of the development level, Taghouti et al. (2015) argued that richer countries are less likely to fail a SPS control, due to more developed pre-export facilities.

The number of RASFF notifications on a product $\mathrm{i}$ from the exporting country $\mathrm{j}, N_{\mathrm{jt}}$, is assumed influenced by W but also by other political economy considerations, affecting lobby activities by producers and consumers:

$$
N_{i j t}=\phi\left(\ell_{s}, \ell_{o}, W\right) \quad \text { Eq. } 2
$$

It can be hypothesized that product notifications in period t, $N_{j i}$, are path-dependent on previous product notifications $N_{j t-1}$. As indicated above, this hypothesis is related to aspects such as the reputation of the product (related on the number of previous controls) and the stickiness of the control measures that have been activated in previous periods. It can also be considered that the country reputation, related to the total number of notifications received in 
Chapter 4. Implications of changing aflatoxin standards for EU border controls on nut imports

previous periods can also influence the current border controls $\left(N_{\mathrm{jt}-1}\right)$, leading to an extended version of Eq. 2 that is expressed by:

$N_{i j t}=\phi\left(\ell_{s}, \ell_{\sigma}, W, N_{i j t-1}, N_{j t-1}\right)$

Eq. 3

In order to measure consumer awareness, the RASFF database allows to identifying events requiring rapid action, which are called "alerts" (EC Regulation XX/2011). Alerts include products that MS have withdrawn or are in the process of being withdrawing from the market $\left(A_{i}\right)$. Lobbying activities by consumers are also affected by $A_{i}$ and by scientific evidences on AF problems $(S)$. Consumer concerns $\left(\omega_{c}\right.$ and $\left.\ell_{c}\right)$ can be also shaped the level and origin of imports in each HS6 chapter $\left(M_{i j t}\right)$. As for producers, we base on Swinnen and Vandemoortele (2011) to propose that aflatoxin standards can be also affected by the import level from different countries, $M_{i j}$, and by the domestic production each kind of nuts in the $\mathrm{EU}\left(Q_{i t}\right)$ that may increase the producers' lobbying activities $\left(\mathscr{\ell}_{s}\right)$. Table 7 summarizes the different variables we can consider to explain the number of RASFF notification on AF:

Table 7. Conceptual variables and explanatory events

\begin{tabular}{ll}
\hline Conceptual variable & Explanatory events and indicators \\
Capacity of exporting countries $\left(\chi_{j}\right)$ & $\begin{array}{l}\text { Development level }\left(\text { per capita } G D P_{j}\right) \\
\text { Country reputation }\left(N_{j t-1}\right)\end{array}$ \\
\hline Consumer concerns $\left(\omega_{c}\right.$ and $\left.\boldsymbol{\ell}_{c}\right)$ & $\begin{array}{l}\text { Alerts }\left(A_{i}\right) \\
\text { Scientific awareness }(S), \\
\text { Imports from different origins }\left(M_{i j}\right)\end{array}$ \\
\hline Producer concerns $\left(\omega_{s}\right.$ and $\left.\boldsymbol{\ell}_{s}\right)$ & Imports from different origins $\left(M_{i j}\right)$ \\
\hline & Production of different nuts $\left.\left(Q_{i t}\right)\right)$ \\
\hline Path dependence effects & Previous product notifications $\left(N_{i j t-1}\right)$ \\
& Country reputation $\left(N_{j t-1}\right)$ \\
\hline
\end{tabular}


Chapter 4. Implications of changing aflatoxin standards for EU border controls on nut imports

In a reduced form, we assume that the log of notification count of the product $(i)$ and exporter $(j)$ and at period $(t)$, is predicted by a linear combination, given by equation (1):

$$
\begin{gathered}
N_{i, j t}=\exp [\underbrace{\beta_{0}+\beta_{1} N_{i j(t-1)}}_{\begin{array}{c}
\text { Product } \\
\text { notifications }
\end{array}}+\underbrace{\beta_{2} N_{j(t-1)}}_{\begin{array}{c}
\text { Country } \\
\text { reputation }
\end{array}}+\underbrace{\beta_{3} A_{i j(t-1)}}_{\text {Product alerts }}+\underbrace{\beta_{4} \ln S_{(t-1)}}_{\text {Scientific awareness }} \\
+\underbrace{\beta_{\mathrm{s}} \ln G D P_{j(t-1)}}_{\begin{array}{c}
\text { Per capita GDP of } \\
\text { the exporting country }
\end{array}}+\underbrace{\beta_{6} \ln M_{i j(t-1)}}_{\text {Import level }}+\underbrace{\beta_{7} \ln Q_{i(t-1)}}_{\text {Production level }}+\underbrace{}_{8} \beta_{\text {Tariff } s_{i t}}+\underbrace{\left.\delta_{i}+\delta_{j}\right]}_{\text {Fixed effects }}
\end{gathered}
$$

where $\delta_{I}$ and $\delta_{j}$ represent fixed effects for product $(i)$ and exporter $(j)$.

We expect that coefficients $\beta_{1}$ and $\beta_{3}>0$ showing a positive response of current notifications to previous controls and alerts. $\beta_{6}$ and $\beta_{7}$ are also expected $>0$ as larger imports and domestic production may increase consumer and producer awareness towards more frequent controls and border measures. $\beta_{2}$ can be positive or negative as it includes the response of border controls to country reputation through the increase in notifications, but also the adoption by exporters of control measures to improve compliance, diminishing the issuing of notifications. $\beta_{5}$ is hypothesized to be $<0$ as it is expected that higher per capita GDP imply better quality control at the exporting country. Finally, $\beta_{4}$ is also expected to be $>$ 0 as the odds of border controls may react positively to higher scientific awareness on the AF problem in nuts.

Impacts of regulatory changes can be analyzed through two dummy variables D1 and D2, the first one referring to the period 1998-2001, previous to harmonization of AF standards $(\mathrm{d} 1=1$ for $\mathrm{t}<2002$, and 0 for $\mathrm{t}>2002)$ and the second one referring to the period $2010-$ 2015, after the convergence to Codex standard $(\mathrm{d} 1=0$ for $\mathrm{t}<2010$, and 1 for $\mathrm{t}>2010)$. Both dummies also interact with $N_{i \bar{i}(t-1)}, N_{j(t-1)}$ and $A_{i(t-1)}$ so we can assess whether policy changes affected the path dependence effects and the notifications' response to alerts.

Scientific awareness: There are various methods have been used to specify an information index based on news or scientific articles count. Smith et al. (1988) suggest the index as the number of articles published on the topic of interest in each period. More 
Chapter 4. Implications of changing aflatoxin standards for EU border controls on nut imports

specifically, Brown and Schrader (1990) suggest another different technique to deal with cholesterol problem in shell egg consumption in the US: the index was built by counting the number of articles with unfavorable news minus the number of articles with favorable news. Chern and Zuo (1997) developed the cumulative method employed by Brown and Schrader (1990) by introducing new fat and cholesterol information index considering then a differentiated carryover weight for favorable and unfavorable articles. Based on Chern and Zuo (1997), Hassouneh et al. (2012) developed a food scare information index, using a monthly count of newspaper articles published in the most popular Egyptian newspaper, to analyze the effect of the avian influenza on price transmission along the Egyptian poultry marketing chain.

In our study, the scientific incidence index (SI) built upon a count of scientific articles and references (both supporting and non-supporting) have been published in each year in the period 1998-2015, to deal with aflatoxins problems of nuts in Europe. We introduced this variable to determine the impact of scientific incidence on European behavior in controlling imported nuts and groundnut. This index presents an approximation to social society' awareness about the impact of aflatoxin contamination on European consumer health. The SI is based on Smith et al (1988).

\subsection{Data and estimation procedure}

The Poisson and Binomial models have been widely used to model count data. The Negative Binomial model is more flexible than Poisson regression model and overcomes the problem of overdispersion that plagues Poisson regression model (Cameron and Trivedi, 2013). Therefore, the negative binomial model can be implemented to quantify more effectively the parameters in case of overdispersion. Furthermore, to account for overdispersion, the high number of zeros in the response variable suggests the use of ZINB model (Lambert, 1992; Greene, 1994).

As indicated above, our original database includes 65 countries including bilateral trade volumes for HS6 product categories to the group of former 15 EU states. Three major problems were found in building the database: The conversion of all recorded notifications from verbal form to HS code (2) the over-dispersion in the data and (3) the excess of zeros in observations. Moreover, a question emerges on how explaining trade flows with zero notifications. The reason for this becoming an issue is because two processes could produce zero notifications, according to literature on trade modeling (Burger et al., 2009; Portugal- 
Chapter 4. Implications of changing aflatoxin standards for EU border controls on nut imports

Perez et al., 2010; Reyes, 2012). The first process is the absence of trade, which leads to zero notifications. The second process that can also produce zero notifications is the compliance with the EU food control system. Such double process obliges to discriminate trade flows through a two-stage estimation. The first stage consists of a logit regression, which determines the likelihood of zero notifications, with variables correlated with such probability, including the lagged import flows. The second stage explains the notification count for the group of products with non-zero probability of trade, and therefore, of having a positive number of notifications. ${ }^{21}$ The double process can be represented through a ZINB model that contains an extra proportion of zeros (p) specified by the following probability density function:

$$
\begin{gathered}
\operatorname{Prob}\left(N=N_{i j t k} \mid \Omega\right) \\
\left\{\begin{array}{c}
p+(1-p) \pi\left(N_{i j t k}=0 \mid \Omega\right) \text { if } N_{i j t k}=0 \\
(1-p) \pi\left(N_{i j t k} \Omega\right) \text { if } N_{i j t k}>0
\end{array}\right\}
\end{gathered}
$$

Where the NB distribution is represented by $\pi\left(N_{\mathrm{v} j \mathrm{k}} \Omega\right)$

The choice of the preferred model that best represents the data is based on goodness of fit tests. The most commonly used criteria for comparison purpose between models are Akaike Information Criterion (AIC), the Bayesian Information Criterion (BIC), the likelihood ratio test and the Vuong statistic test. Table 8 provides summary statistics of these parameters. All four statistical tests indicate that the ZINB would be the preferred one over the negative binomial specification. Indeed, the former will be used to analyze the relationship between the AF notification of nuts and the aforementioned variables.

Table 8. NB and ZINB models, Goodness of fit parameters

\begin{tabular}{ccc}
\hline & $\begin{array}{c}\text { Zero-Inflated Model } \\
(\text { ZINB })\end{array}$ & $\begin{array}{c}\text { Negative Binomial } \\
\text { Model (NBM) }\end{array}$ \\
\hline AIC & 23420 & 26942 \\
\hline BIC & 32960.00 & 27209.51 \\
\hline Log Likelihood & -11672.16 & -26883.60 \\
\hline Num. observations & \multicolumn{3}{c}{75960} \\
\hline Vuong Test ${ }^{22}$ & $22.76^{* * *}$ \\
\hline & Source: Authors' calculations
\end{tabular}

\footnotetext{
${ }^{21}$ The signs of the coefficients in the logit model are usually opposite to those in the NB part.

${ }^{22}$ Vuong test value represents $\mathrm{z}$-score statistic. The model was estimated using R-language.
} 
Chapter 4. Implications of changing aflatoxin standards for EU border controls on nut imports

In this exercise, the dependent variable $\left(N_{i j t}\right)$ is a non-negative count variable explained in terms of a set of covariates. The estimation of regression parameters using the maximum likelihood method is presented in table 12. All variables that are correlated with the probability of zero notifications were included in the logit part of the ZINB model. Therefore, the following variables were included in mentioned part of the model : The lagged product notifications, the lagged exporting country notifications, the lagged alerts notifications, the lagged logarithm of GDP per capita of exporting countries and the lagged import value.

Table 9. Estimated parameters of ZINB Model

\begin{tabular}{|c|c|c|}
\hline & ZINB & \\
\hline & Negative binomial & Logit \\
\hline (Intercept) & $\mathbf{- 1 . 6 6 0 3 2}(0.11630)^{* * *}$ & $2.58588(0.10507)^{* * *}$ \\
\hline $\mathrm{N}_{\mathrm{ijt}-1}$ & $\mathbf{0 . 0 2 1 0 1}(0.00180)^{* * *}$ & $\mathbf{- 2 . 6 9 7 5 5}(0.12440)^{* * *}$ \\
\hline $\mathrm{N}_{\mathrm{jt}-1}$ & $\mathbf{- 0 . 0 1 4 8 8}(0.00166)^{* * *}$ & $\mathbf{- 0 . 0 0 7 1 6}(0.00165)^{* * *}$ \\
\hline $\mathrm{A}_{\mathrm{ijt}-1}$ & $\mathbf{0 . 2 1 3 8 0}(0.02949)^{* * *}$ & $\mathbf{0 . 7 2 1 9 0}(0.32290)^{*}$ \\
\hline $\operatorname{Ln}\left(p c G D P_{\mathrm{t}-1}\right)$ & $\mathbf{- 0 . 0 0 0 3 1}(0.00012)^{*}$ & $0.00013(0.00011)$ \\
\hline $\operatorname{Ln}\left(\mathrm{M}_{\mathrm{ijt}-1}\right)$ & $\mathbf{0 . 0 0 0 2 3}(0.00005)^{* * *}$ & $\mathbf{- 0 . 0 0 0 3 3}(0.00006)^{* * *}$ \\
\hline $\operatorname{Ln}\left(Q_{i t-1}\right)$ & $\mathbf{0 . 0 0 4 4 3}(0.00214)^{*}$ & $\mathbf{0 . 0 1 6 3 3}(0.00255)^{* * *}$ \\
\hline $\operatorname{Ln}\left(\mathrm{S}_{\mathrm{t}}\right)$ & $\mathbf{0 . 0 4 8 0 6}(0.00836)^{* * *}$ & $\mathbf{0 . 0 1 8 4 7}(0.00766)^{*}$ \\
\hline Dummy 1998-2001 & $\mathbf{- 1 . 3 6 9 8 4}(0.08977)^{* * *}$ & \\
\hline Nijt.1 & $\mathbf{0 . 1 1 6 4 0}(0.02111)^{* * *}$ & \\
\hline Njt.1 & $\mathbf{- 0 . 0 9 5 3 1}(0.01926)^{* * *}$ & \\
\hline$A_{i j t-1}$ & $\mathbf{0 . 5 6 1 2 1}(0.07701)^{* * *}$ & \\
\hline Dummy 2010-2015 & $\mathbf{- 0 . 8 2 3 4 5}(0.07647)^{* * *}$ & \\
\hline Nijt.1 & $\mathbf{0 . 0 4 6 0 8}(0.00586)^{* * *}$ & \\
\hline Njt.1 & $\mathbf{- 0 . 0 1 0 4 4}(0.00297)^{* * *}$ & \\
\hline $\mathrm{A}_{\mathrm{ijt}-1}$ & $\mathbf{- 0 . 1 8 6 5 5}(0.05233)^{* * *}$ & \\
\hline Country fixed effects & $* * *$ & \\
\hline Product fixed effects & $* * *$ & \\
\hline $\log ($ theta $)$ & $\mathbf{- 0 . 0 6 6 9 8}(0.05407)^{* * *}$ & \\
\hline AIC & 23420.32313 & \\
\hline Log Likelihood & -11672.16157 & \\
\hline Num. obs. & 75960 & \\
\hline
\end{tabular}

${ }^{* * *} \mathrm{p}<0.001,{ }^{* *} \mathrm{p}<0.01,{ }^{*} \mathrm{p}<0.05$

Source: Authors' calculations

Table 9 presents the descriptive statistics of variables used in our estimation. Modeling count data can be challenging in case of having overdispersed data with an excessive presence 
Chapter 4. Implications of changing aflatoxin standards for EU border controls on nut imports

of zeros. Indeed, we note that the standard deviation of almost all variables is greater than the mean which indicate the problem of overdispersion in our dataset. In addition, we can note the enormous amount of zero observations (number of notifications for a given 'productcountry of origin-year') ${ }^{23}$. These facts point to the same conclusion indicated by the estimations of goodness of fit parameters indicated in table 8 .

Table 10. Descriptive statistics

\begin{tabular}{|c|c|c|c|c|c|c|c|}
\hline Variable & Unit & Source & Mean & Std.Dev & Min & Max & $\begin{array}{l}\% \text { of } \\
\text { zeroes }\end{array}$ \\
\hline Nijt & Not. & RASFF & 0.31 & 7.24 & 0 & 489 & 96.80 \\
\hline Nijt-1 & Not. & RASFF & 0.30 & 7.23 & 0 & 489 & 97.01 \\
\hline Njt-1 & Not. & RASFF & 3.94 & 26.21 & 0 & 490 & 70.48 \\
\hline Alerts $_{\mathrm{ijt}-1}$ & Not. & RASFF & 0.01 & 0.23 & 0 & 10 & 99.32 \\
\hline Import $_{\text {ijt }-1}{ }^{24}$ & $€$ & $\begin{array}{l}\text { Comext- } \\
\text { Eurostat }\end{array}$ & 351.33 & 797.19 & 1 & 764641430.10 & 0 \\
\hline $\begin{array}{c}\text { European } \\
\operatorname{prod}_{\text {it-1 }}\end{array}$ & $1000 \mathrm{~T}$ & Eurostat & 13.74 & 23.39 & 6.47 & 966.71 & 0 \\
\hline $\mathrm{GDP} p c_{\mathrm{t}-1}$ & US\$ & $\begin{array}{l}\text { World } \\
\text { Bank }\end{array}$ & 458.38 & 326.10 & 244.137 & 54232.65 & 0 \\
\hline $\begin{array}{l}\text { Scientific } \\
\text { incidence }_{t}\end{array}$ & $\begin{array}{l}\text { Num of } \\
\text { articles }\end{array}$ & $\begin{array}{l}\text { Google } \\
\text { scholar }\end{array}$ & 441.22 & 224.20 & 95 & 834 & 0 \\
\hline
\end{tabular}

Source: Authors' calculations

\subsection{Findings and discussion}

Elasticities or rates of responses of the AF notification count to the model variables are shown in Table 10, with specific parameters estimated for the period before the harmonization of AF standards ('Pre-EU harmonization' 1998-2001), for the period before the harmonization of EU standards to Codex maximum levels ('Pre-Codex' 2002- 2009) and for the period after the harmonization of EU standards to Codex ('Post-Codex" 2010-2015).

Our results show that the European controls of AF in imported nuts depend on the past history of product and exporter's AF notifications, showing that countries or sectors able to

\footnotetext{
${ }^{23}$ There are 75,960 observations from the 6590 notifications.

${ }^{24} \mathrm{GDP}_{\text {pct-1 }}$ and Import $_{\mathrm{ijt}-1}$ are at constant 2010 prices.
} 
Chapter 4. Implications of changing aflatoxin standards for EU border controls on nut imports

have the "house in order" are less sensitive to deficiencies in compliance (Diaz Rios and Jaffe, 2008). These reputation effects are more relevant for the 'Pre-EU harmonization' period. This is also the case for the notification response to alerts, which refer to events requiring rapid action in the market. Such reduction of the path dependence effects on product notifications and past alerts in the later periods would suggest that the safety controls are increasingly more systematic and less dependent on reputation or past controls. Country reputation effects (on variable $\mathrm{N}_{\mathrm{Jt}-1}$ ) are significant and negative, which indicates that countries facing an increase in notifications may manage the surge of notifications by shifting exports or strengthening export controls in later years. Again, such reactions are more pronounced in the 'Pre-EU harmonization' period.

The negative and significant elasticity of the notification count to per capita GDP suggests that development may be coupled with increased capacity to comply with EU standards, though absolute elasticity is quite low. Similarly, notifications are positively affected by previous production and import values, which would be in line with the hypothesis that producers concerns could affect import controls, although again with low elasticities. An interesting finding is that the elasticity of the notification count to the number of published scientific references is significant; showing that $1 \%$ increase in scientific references on EU food standards would imply $4.81 \%$ increase in the AF notification count. 
Chapter 4. Implications of changing aflatoxin standards for EU border controls on nut imports

Table 11. Impact on count notifications per period

\begin{tabular}{|c|c|c|c|}
\hline & $\begin{array}{c}\text { Pre-harmonization } \\
\text { of EU standards }\end{array}$ & Pre Codex & Post Codex \\
\hline Per 1 unit change in & $1998-2001$ & $2002-2009$ & $2010-2015^{25}$ \\
\hline $\mathrm{N}_{\mathrm{ijt}-1}$ & 13.74 & 2.10 & 6.71 \\
\hline $\mathrm{N}_{\mathrm{Jt}-1}$ & -11.02 & -1.49 & -2.53 \\
\hline Alerts $_{\mathrm{ijt}-1}$ & 77.50 & 21.38 & 2.73 \\
\hline \multicolumn{4}{|l|}{ Per $1 \%$ increase in } \\
\hline Imports $\mathrm{ijt}_{-1}$ & & 0.023 & \\
\hline $\begin{array}{l}\text { European } \\
\text { production }_{\text {it- } 1}\end{array}$ & & 0.443 & \\
\hline $\operatorname{pcGDP}_{(\mathrm{t}-1)}$ & & -0.031 & \\
\hline $\begin{array}{l}\text { Scientific } \\
\text { referencest }\end{array}$ & & 4.81 & \\
\hline
\end{tabular}

\begin{tabular}{lccc} 
Fixed effect period & 0.25 & 1 & 0.43 \\
\hline
\end{tabular}

As illustrated in Table 11, a scenario of no implementation of Codex regulations was simulated for the period 2013-2015. We observed that the notification count under such scenario would have almost doubled the observed count, with varying patterns among different suppliers and products. South Africa, United States and Argentina appear to be the most benefited countries of applying the Codex limit. These countries have followed a proactive strategy to prevent AF contamination and establish efficient certifications systems (Diaz Rios and Jaffee, 2008). The lessening of the AF standard is effective when a significant number of controls already complied with the more flexible Codex standard but it did not meet the tighter MRL. In the opposite situation, Egypt, Turkey and China, seem to be less benefited by lessening of the EU standard, perhaps because their proportion of safety problems above Codex levels was already significant. Therefore, the change in the number of NTMs benefits some countries more than others. In these countries, the reduction of AF problems would depend more on their own control capacity than on the change in EU regulation.

\footnotetext{
${ }^{25}$ Coefficients are estimated by adding up the coefficients of mentioned variables in the reference period (20022009 ) to the coefficients of the interaction terms for each period in the estimated model depicted in table 5.
} 
Chapter 4. Implications of changing aflatoxin standards for EU border controls on nut imports

Table 12. Average notification count (2013-2015): No Codex scenario

\begin{tabular}{|c|c|c|c|c|}
\hline & & Non Codex scenario & Observed w/Codex & $\begin{array}{c}\% \text { Impact on } \\
\text { notification count }\end{array}$ \\
\hline \multirow{10}{*}{ 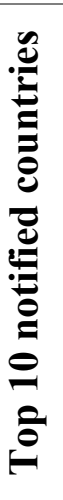 } & South Africa & 12 & 3 & -78 \\
\hline & United States & 67 & 26 & -62 \\
\hline & Argentina & 9 & 4 & -53 \\
\hline & India & 24 & 13 & -45 \\
\hline & Brazil & 19 & 11 & -41 \\
\hline & Nigeria & 2 & 1 & -40 \\
\hline & Iran & 51 & 35 & -32 \\
\hline & Egypt & 10 & 9 & -13 \\
\hline & Turkey & 55 & 49 & -11 \\
\hline & China & 56 & 54 & -3 \\
\hline \multirow{3}{*}{ 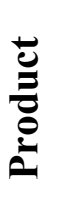 } & Pistachios & 98 & 51 & -48 \\
\hline & Groundnut & 80 & 56 & -43 \\
\hline & Almond & 4 & 3 & -25 \\
\hline \multicolumn{2}{|c|}{ Nuts total } & 196 & 103 & -47 \\
\hline
\end{tabular}

\subsection{Conclusion}

Edible nuts exports to the EU remain heavily dependent on restrictive controls of AF carried out by MS, which affect the economy of nuts producers. In this paper, a model to explain the RASFF notification count was conceptually defined and estimated to assess the effect of changing AF standards in the EU. NTMs appear to react to domestic consumer and producer concerns, but they also depend on the export capacity of nut suppliers to the EU and even more on the scientific awareness on the effects of AF on health. Implementation of NTMs is affected by product and country reputation, with significant impact of events requiring rapid action in the market. The count model on RASFF notifications allows to evaluating the impact of changing AF standards, once isolated the effect of economic and political variables. Countries that employed substantial efforts to upgrade the safety of their exports will probably be the most benefited of removing or lessening of NTMs. Although this paper provides some light on the factors explaining the enforcement of food safety controls, further research is needed to analyze the trade effects on nut exports to the EU derived on the change of AF standards. Standard reforms could be also considered endogenous in the model, which opens an interesting field for future research. 
Chapter 4. Implications of changing aflatoxin standards for EU border controls on nut imports

\section{References}

Baylis, K., Martens, A., \& Nogueira, L. (2009). What drives import refusals? American Journal of Agricultural Economics, 91(5), 1477-1483.

Beghin, J. C., Maertens, M., \& Swinnen, J. (2015). Non tariff measures and standards in trade and global value chains. Annual Review of Resource Economics, 7(1), 425-450.

Brown, D.J. \& Schrader, I.F. (1990). Information on cholesterol and falling shell egg consumption. American Journal of Agricultural Economics, 72(3), 548-555.

Burger, M., van Oort, F., \& Linders, G. (2009). On the specification of the gravity model of trade: Zeros, excess zeros and zero-inflated estimation. Spatial Economic Analysis, 4(2), 167-190. http://dx.doi.org/10.1080/17421770902834327

Buzby, J. C. (2003). International trade and food safety: economic theory and case studies. Washington, DC: US Department of Agriculture, Economic Research Service.

Cameron, A. and Trivedi, P. (2013). Regression Analysis of Count Data (2nd ed.). Cambridge University Press, Cambridge, UK.

Centers for Disease Control and Prevention (CDC) (2004). Outbreak of aflatoxin poisoning Eastern and Central provinces, Kenya. http://www.cdc.gov/mmwr/preview/mmwrhtml/mm5334a4.htm

Chern, W.S., \& Zuo, J. (1997). Impacts of fat and cholesterol information on consumer demand: Application of news indexes. Working Paper, The Ohio State University, Columbus, Ohio.

Committee on Sanitary and Phytosanitary Measures, World Trade Organization (1999). Summary of the Meeting Held on 10-11 March 1999, G/SPS/R/14, World Trade Organization, Geneva.

Emmott, A., \& Stephens, A. (2012). Scoping economically viable mechanisms that deliberately pull aflatoxin out of human food chains. Twin and twin trading, London, UK www.twin.org.uk/sites/default/files/images/Liz-folder/documents/DFIDMalawi-report-forweb-0912.pdf

European Commission (2001). Commission Regulation (EC) No 466/2001 of 8 March 2001, Official Journal of the European Communities.

European Commission (2002). Commission Regulation (EC) No 472/2002 of 12 March 2002, Official Journal of the European Communities. 
Chapter 4. Implications of changing aflatoxin standards for EU border controls on nut imports

European Commission (2006). Commission Regulation (EC) No 1881/2006 of 19 December 2006, Official Journal of the European Communities.

European Commission, The Rapid Alert System for Food and Feed (RASFF). Annual Report 2002-2015.

FAO/WHO (Food and Agriculture Organisation and World Health Organisation) (1997). Acceptable Daily Intakes, Other Txicological Information, and Information on Specifications. Joint FAO/WHO Expert Committee on Food Additives, Rome, 17-26 June 1997.

Ferro, E., Otsuki, T., \& Wilson, J. S. (2015). The effect of product standards on agricultural exports. Food Policy, 50: 68-79.

Greene, W. (1994). Accounting for excess zeros and sample selection in Poisson and negative binomial regression models. Leonard N. Stern School of Business, New York University, USA.

Grossman, G. M. \& Helpman, E. (1992). Protection for sale (No. w4149). National Bureau of Economic Research.

Hassouneh, I., Radwan, A., Serra, T. \& Gil, J. (2012). Food scare crises and developing countries: The impact of avian influenza on vertical price transmission in the Egyptian poultry sector. Food Policy, 37(3), 264-274.

Henson, S., Loader, R., Swinbank, A., Bredahl, M., \& Lux N. (2000). Impact of sanitary and phytosanitary measures on developing countries. Reading: University of Reading, Center for Food Economics Research.

International Trade Center. Trade Map, 2016.

Jaud, M., Cadot, O., \& Suwa-Eisenmann, A. (2013). Do food scares explain supplier concentration? An analysis of EU agri-food imports. European Review Of Agricultural Economics, 40(5), 873-890.

Jouanjean, M., Maur, J., \& Shepherd, B. (2012). Reputation Matters: Spillover Effects in the Enforcement of US SPS Measures. Non-Tariff Measures. In A Fresh Look at Trade Policy's New Frontier (1st Ed.). The International Bank for Reconstruction and Development. The World Bank. NW, Washington, USA.

Jouanjean, M., Maur, J., \& Shepherd, B. (2015). Reputation matters: Spillover effects for developing countries in the enforcement of US food safety measures. Food Policy, 55: 8191. 
Chapter 4. Implications of changing aflatoxin standards for EU border controls on nut imports

Kallummal, M., Gupta, A. \&Varma, P. (2013). Exports of agricultural products from SouthAsia and impact of SPS measures: A case study of European Rapid Alert System for Food and Feed (RASFF). Journal of Economic Policy \& Research, 8(2), 41-75.

Kleter, G., Prandini, A., Filippi, L., \& Marvin, H. (2009). Identification of potentially emerging food safety issues by analysis of reports published by the European Community's Rapid Alert System for Food and Feed (RASFF) during a four-year period. Food and Chemical Toxicology, 47(5), 932-950.

Lambert, D. (1992). Zero-Inflated Poisson Regression, with an Application to Defects in Manufacturing. Technometrics, 34(1), 1-14.

May, P., \& Winter, S. (2000). Reconsidering styles of segulatory enforcement: Patterns in Danish agro-environmental inspection. Law \& Policy, 22(2), 143-173.

Nielsen, C.P. \& Kym A. (2000) GMOs, Trade policy, and welfare in rich and poor countries. In Maskus, K.E. \& Wilson, J.S. (Eds.) Quantifying Trade Effect of Technical Barriers: Can it be done? University of Michigan Press, Ann Arbor MI.

Otsuki T, Wilson J.S., and Sewadeh, M. (2001). What price precaution? European harmonization of aflatoxin regulations and African groundnut exports. European Review of. Agricultural. Economics, 28(3), 263-283.

Pinstrup-Andersen, P., (2000). Food policy research for developing countries: Emerging issues and unfinished business. Food Policy, 25(2), 125-141.

Portugal-Perez, A., Reyes, J. D., \& Wilson, J. S. (2010). Beyond the information technology agreement: Harmonisation of standards and trade in electronics. The World Economy, 33(12), 1870-1897.

Reyes, J.D. (2012). The pro-competitive effect of international harmonization of product standards. Non-tariff Measures: A Fresh Look at Trade Policy's New Frontier, O. Cadot, and M. Malouche (eds.), London/Washington, DC: CEPR/ World Bank.

Rios, L.D. \& Jaffee, S, (2008). Standards, competitiveness, and Africa's groundnut exports to Europe: Barrier, catalyst, or distraction?. Agriculture \& Rural Development Department. Discussion Paper 39. The International Bank for Reconstruction and Development/the World Bank.

Smith, M.E., Van Ravenswaay, E.O., \& Thompson, S.R., (1988). Sales loss determination in food contamination incidents: an application to milk bans in Hawaii. American Journal of Agricultural Economics, 70(3), 513-520. 
Chapter 4. Implications of changing aflatoxin standards for EU border controls on nut imports

Strosnider, H., Azziz-Baumgartner, E., Banziger, M., Bhat, R. V., Breiman, R., Brune, M. N., ... \& Henry, S. H. (2006). Workgroup report: public health strategies for reducing aflatoxin exposure in developing countries. Environmental health perspectives, 114(12), 1898.

Swinnen, J. (2010). The political economy of agricultural and food policies: recent contributions, new insights, and areas for further research. Applied Economic Perspectives and Policy, 32(1), 33-58.

Swinnen, J. (2016). Economics and politics of food standards, trade, and development. Agricultural Economics, 47(S1), 7-19.

Swinnen, J., \& Vandemoortele, T. (2011). Trade and the political economy of food standards. Journal of Agricultural Economics, 62(2), 259-280.

Taghouti, I., Martinez-Gomez, V., \& Garcia-Alvarez-Coque, J.M. (2015). Exploring EU food safety notifications on agro-food imports: Are Mediterranean Partner Countries discriminated?. International Journal of Food and Agricultural Economics, 3(2), 15-29.

Taghouti, I., Martinez-Gomez, V., \& Marti, L. (2016). Sanitary and phytosanitary measures in agri-food imports from the European Union: Reputation effects over time. Economía Agraria y Recursos Naturales, 16(2), 69-88.

Tudela-Marco, L., Garcia-Alvarez-Coque, J.M., \& Martí-Selva, L. (2016). Do EU member states apply food standards uniformly? A look at fruit and vegetable safety notifications. Journal of Common Market Studies, 55(2), 387-405.

Versluis, E. (2007). Even rules, uneven practices: Opening the 'Black Box' of EU law in action. West European Politics, 30(1), 50-67.

Vigani, M., \& Olper, A. (2013). GMO standards, endogenous policy and the market for information. Food Policy, 43(2013), 32-43.

Wilson, John S. (2000). The development challenge in trade: Sanitary and phytosanitary standards. Paper submitted to WTO meeting on sanitary and phytosanitary standards, World Trade Organization, Geneva

Wu, F., \& Guclu, H. (2012). Aflatoxin regulations in a network of global maize trade. PLoS ONE, 7(9), e45141.

Wu, F., Miller, J.D. \& Casman, E.A. (2004). The economic impact of Bt corn resulting from mycotoxin reduction. Toxin Reviews, 23(2-3), 397-424. 
Exploring EU food safety notifications on agrofood imports: Are Mediterranean Partner Countries discriminated? 
Chapter 5 Exploring EU food safety notifications on agro-food imports: Are Mediterranean

Partner Countries discriminated?

\title{
Exploring EU food safety notifications on agro-food imports. Are Mediterranean Partner Countries discriminated? ${ }^{26}$
}

\author{
Ibtissem Taghouti ${ }^{1}$ \\ Victor Martinez-Gomez ${ }^{1}$ \\ Jose Maria Garcia Alvarez-Coque ${ }^{1}$ \\ ${ }^{1}$ Department of Economics and Social Sciences; \\ Group of International Economics and Development; \\ UPV-UniversitatPolitècnica de València, Spain
}

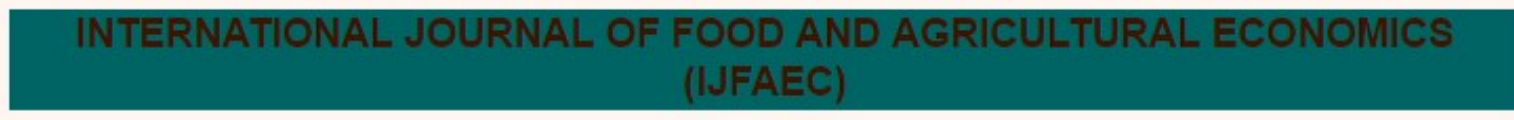

\section{Vol. 3 Issue 2 (Special Issue) April 2015}

Editorial (PDF)
Genetically Modified Crops: International Trade and Trade Policy Effects Full Text (PDF)
George Frisvold and Jeanne Reeves
Exploring EU Food Safety Notifications on Agro-Food Imports: Are Mediterranean Partner Countries
Discriminated? Full Text (PDF)
Ibtissem Taghouti, Victor'Martinez-Gomez and José Maria Garcia Alvarez Coque
OECD Agricultural Subsidies and Poverty Rates In Lower Income Countries Full Text (PDF)
Ilaria Tedesco, Alessandra Pelloni and Giovanni Trovato
"Banana War" and World Trade Changes Full Text (PDF)
Jaime de Pablo Valenciano, Miguel Angel Giacinti Battistuzzi and Tomás Garcia Azcaráte
Effects of Economic Partnership Agreements on Agricultural Trade between Nigeria and the EU
Full Text (PDF)
Collins Sunday Nwali and Chukwuemeka John Arene
The Potential Impact of a Southern African Common External Tariffs Regime on the Economy of Lesotho
Full Text (PDF)

${ }^{26}$ It was published in the International Journal of Food and Agricultural Economics (IJFAEC) in 2015, volume 3 , number 2, pages 15-29. 
Chapter 5 Exploring EU food safety notifications on agro-food imports: Are Mediterranean Partner Countries discriminated?

\section{Co-author letter}

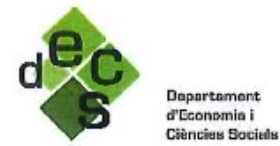

Valencia, 3 february2017

Mr. Victor Martinez-Gomez Co-author of the publication: Exploring EU food safety notifications on agro-food imports: Are Mediterranean Partner Countries discriminated?, published in the "International Journal of Food and Agricultural Economics ", Declares that he agrees with the presentation by the doctoral candidate, Ibtissem Taghouti, of this publication as part of the doctoral thesis; additionally expresses his renounce to the use of this work as part of other doctoral thesis.

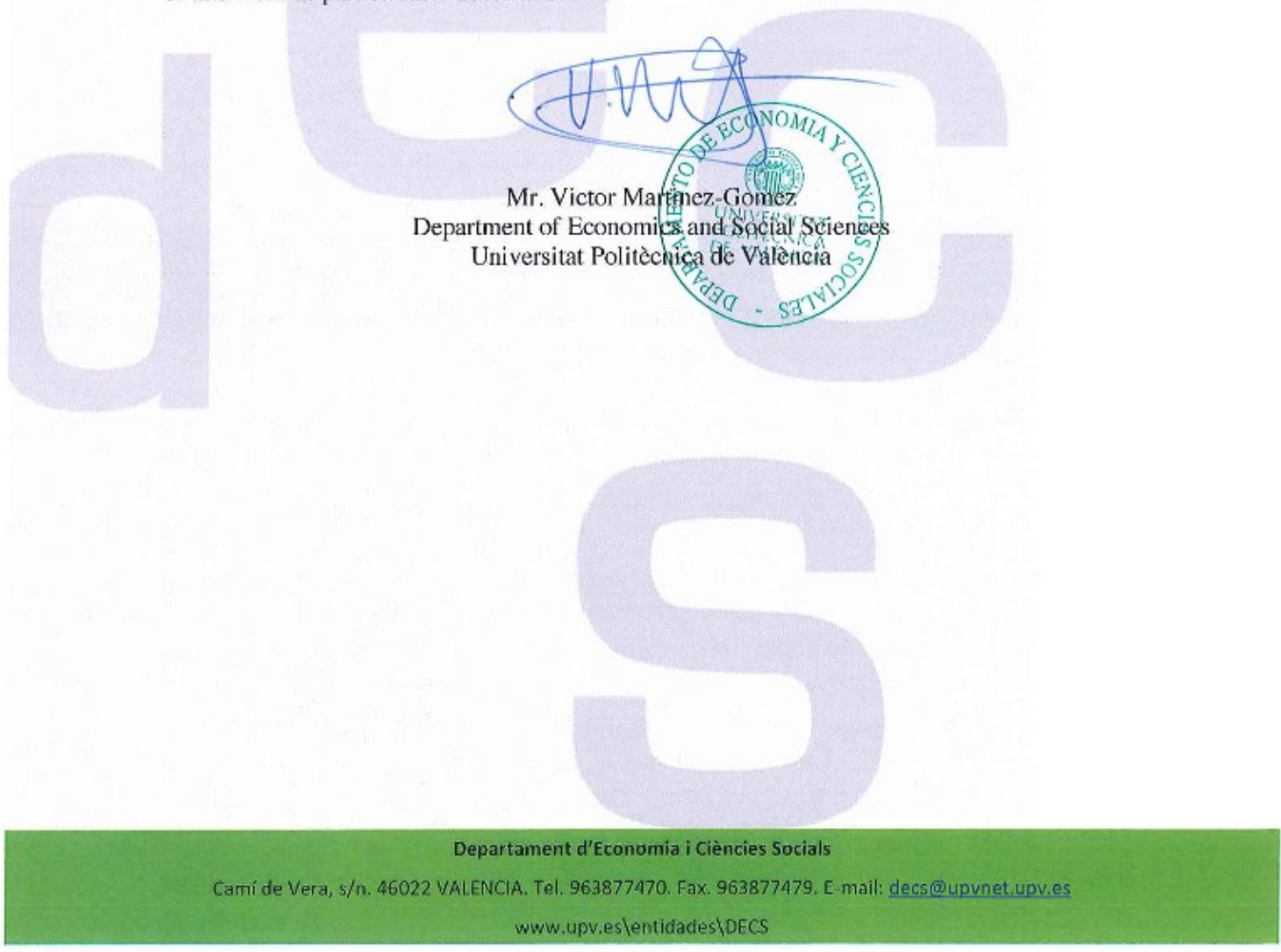

Source: Department of Economics and Social Sciences; Dr. Victor Martinez-Gomez 
Chapter 5 Exploring EU food safety notifications on agro-food imports: Are Mediterranean Partner Countries discriminated?

\section{Co-author letter}

UNIVERSITAT

POLITÉCNICA

DE VALÉNCIA

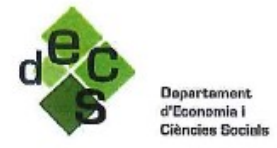

Valencia, 3 february 2017

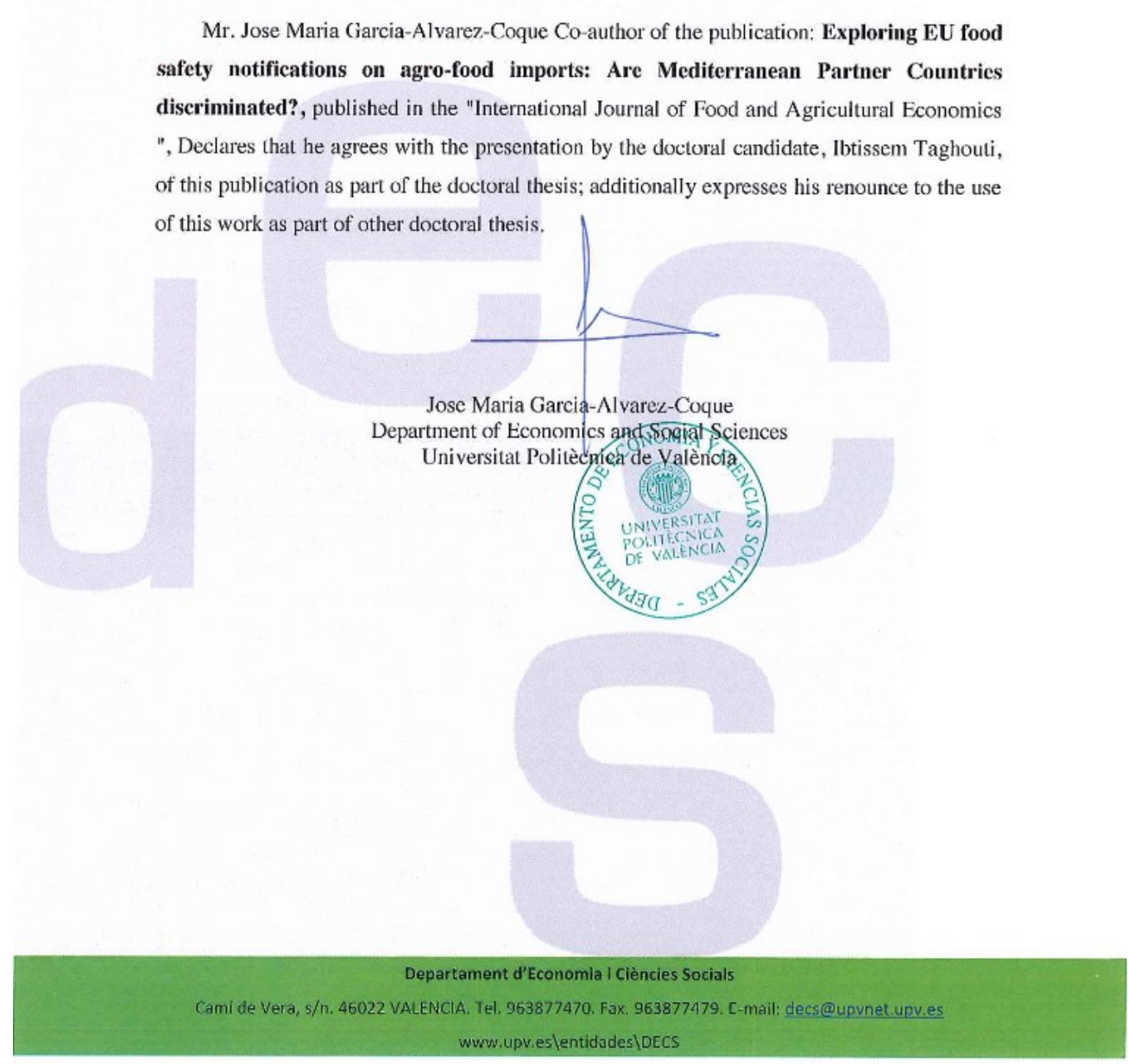

Source: Department of Economics and Social Sciences; Dr. Jose Maria Garcia-Alvarez-Coque 


\title{
Chapter 5. Exploring EU food safety notifications on agro-food imports: Are Mediterranean Partner Countries discriminated?
}

\begin{abstract}
Limited capacity to comply with standards and controls has constrained the trade opportunities generated by bilateral agreements and preferences given to developing countries such as those belonging to the Mediterranean region. Specifically, in this paper we focus on the implementation of a specific type of Non-Tariff Measures that includes food safety concerns by the European Union. This is carried out through exploring some of the influencing factors on food standard enforcement in the EU, which is a major importer of agro-food products from developing countries. The issue at stake emerges on the possible rationale behind the food alerts which can be the result of the management of specific risksbut beyond that by considering the reputation of the product or the country of origin. We aim at exploring the hypothesis that exporters' reputation -which is built on past history of border notifications- affects current decisions on EU implementation of food standards. Methodologically, notifications are extracted from those reported on the Rapid Alert System for Feed and Food (RASFF), and count data models are used to account for the overdispersion existing in them. The results of the paper support the hypothesis that previous food notifications may slightly affect current notifications; nevertheless this effect seems to be less relevant for products of interest for Mediterranean Partner Countries. Hence, we cannot identify a pro or anti Mediterranean bias in the way that food safety controls are implemented at the EU borders.
\end{abstract}

Key words

Non-Tariff Measures, Mediterranean Partner Countries, SPS measures, Agro-food trade.

\subsection{Introduction}

During the last decades, agri-food trade has been rapidly developed since more countries have been integrated in the world trading system. Many efforts have been implemented to make international trade easier and to facilitate markets' access by reducing trade barriers. Even though multilateral and bilateral trade talks have succeeded in eliminating tariff barriers, they still face the challenge of providing a more transparent framework for non-tariff measures 
Chapter 5 Exploring EU food safety notifications on agro-food imports: Are Mediterranean Partner Countries discriminated?

(NTMs). The concept refers to any measure, other than tariffs, which modifies price or quantities traded -see a classical discussion on the definition of the concept in Deardorff and Stern (1997). NTMs are increasingly becoming an important determinant of agri-food trade (OECD, 2005; Cadot et al., 2012). They are employed for different purposes, which sometimes are protectionist (Nimenya et al., 2012), and sometimes to correct information asymmetries and market failures (Disdier et al., 2014).

Literature underlines that the limited resources in developing countries have constrained them to fully benefit from the opportunities generated by multilateral agreements, given their lack of capacity to comply with standards and controls (Michalopoulos, 1999). Considering that the EU is a major importer of agro-food products from developing countries, this paper explores some of the influencing factors on food standard enforcement in the EU. The implementation of food standards on EU agro-food imports has received some attention in the trade literature (García-Martinez et al., 2006). A point to stress is that EU food notifications can be the result of specific food health concerns, what is in line with the aim of correcting market failures. However, we wonder to what extent current notifications are influenced by the past history of food notifications. In short, the question emerges on the possible rationale behind the food notifications, which can be the result of the management of specific risks, but beyond that, of the "reputation" of the product or the country of origin.

We test the hypothesis that the history of notifications on problems leading to NTMs, significantly influences EU behavior on actual notifications. The underlying idea under the concept of reputation is that one product's notifications in one year may affect the probability of future notifications, and that such effects may appear at product, sector and country level. Jouanjean et al. (2012) looked at import refusals providing a first evidence of how reputation affects the enforcement of SPS measures in the US. We turn the analysis to the EU, using a more general notion of notifications on food standards. Food standard enforcement by the EU has received some attention in recent studies, as a determinant of trade (Baylis et al., 2010) or as a dependent variable (Jaud et al., 2013). This last paper does not consider reputation effects.

Product notifications issued by EU MS are registered by the EU border authorities to enforce food safety policy and included in the Rapid Alert System for Food and Feed 
Chapter 5 Exploring EU food safety notifications on agro-food imports: Are Mediterranean Partner Countries discriminated?

$(\mathrm{RASFF})^{27}$, a database that has not been used extensively in trade literature to link the EU food notifications with trade restraints. In fact, to our knowledge, it is only used in Jaud et al. (2013). There are two main methodological challenges that could explain why the use of RASFF database has been limited. The first one is the need to link RASFF data with trade data expressed in terms of a recognized nomenclature such as the HS. To overcome this challenge, this research has involved the design of an algorithm to transform RASFF data into food alerts and notifications classified by HS Code. A second methodological challenge stems from the numerous observations with zero values in this type of datasets. To deal with this, we employed a set of different panel count models. As shown below, literature stresses that the panel count modeling approach has several advantages over individual time series and cross sectional models.

The paper is organized as follows. In the next section, we introduce the concept of reputation in food standard enforcement, and set the hypotheses of this paper. Then, the third section presents the methodology used in our empirical analysis and the way reputation is considered in the model, also indicating the specific treatment applied to include Mediterranean Partner Countries (MPCs) and several products. The fourth section shows the results and discussion of the empirical application. Finally, the paper ends with some concluding remarks.

\subsection{Reputation effects and hypotheses}

The implementation of food safety standards seriously challenges agro-food exports of developing economies (Henson and Jaffee, 2006). The analysis of NTMs' effects on agrofood trade constitutes the mainstream of the literature, often using gravity models (e.g., Otsuki et al., 2001; Wilson and Otsuki, 2004; Disdier et al., 2008; Essaji, 2008; Anders and Caswell, 2009). Maertens and Swinnen (2009) suggested that foreign standards can push up the production quality and help firms to realize beneficial productivity gain. NTMs can also be welfare-improving as they provide to consumers further information and decrease the

27 The Rapid Alert System for Food and Feed was created by the European Commission (EC) to ensure transparency for consumers and business operators. It is used to enhance food safety and to provide the control authorities with an effective tool of exchange of information. Available at http://ec.europa.eu/food/food/rapidalert/index_en.htm. It is worth also to stress non-EU European Economic Area members' notifications also are registered in RASFF. Hereinafter, for the sake of simplicity, we will consider all them as EU notifications. 
Chapter 5 Exploring EU food safety notifications on agro-food imports: Are Mediterranean Partner Countries discriminated?

impact of the asymmetric information problem (Beghin and Bureau, 2001; Movchan, 1999; Disdier et al., 2008; Disdier, 2014).

The EU is an attractive destination for emerging countries exporters, given the relevant size of its agro-food demand, and specifically for MPCs due to the historical trade relations and the geographical proximity. Notifications registered by the EU and included in the RASFF can be classified in four types. First type, Alert notifications, correspond to food that presents a serious health risk and requires rapid action. Second type, Border rejections, is related to food that has been tested and rejected at the external borders of the EU when a health risk has been found. Third type, Information notifications, is used when a risk has been identified about food or feed placed on the market, but the other members do not have to take rapid action. Finally, any information related to food and feed safety, which has not been communicated as an alert or an information notification, but which is judged interesting for the control authorities, is transmitted to the members under the heading 'News'.

Based on RASFF database, Grazia et al. (2009) and Tudela-Marco et al. (2014) provide with analyses of the frequency of EU food notifications on MPCs' exports. The latter paper focuses on notifications imposed by a set of major EU importers concerning Mediterranean countries as origin countries. Figure 9 shows the number of notifications applied by EU authorities on exports from Algeria, Egypt, Jordan, Lebanon, Morocco, Syria Tunisia and Turkey between 2002 and 2011. 
Chapter 5 Exploring EU food safety notifications on agro-food imports: Are Mediterranean Partner Countries discriminated?

Figure 9. Number of notifications applied by EU on agrifood ${ }^{28}$ Mediterranean exporters

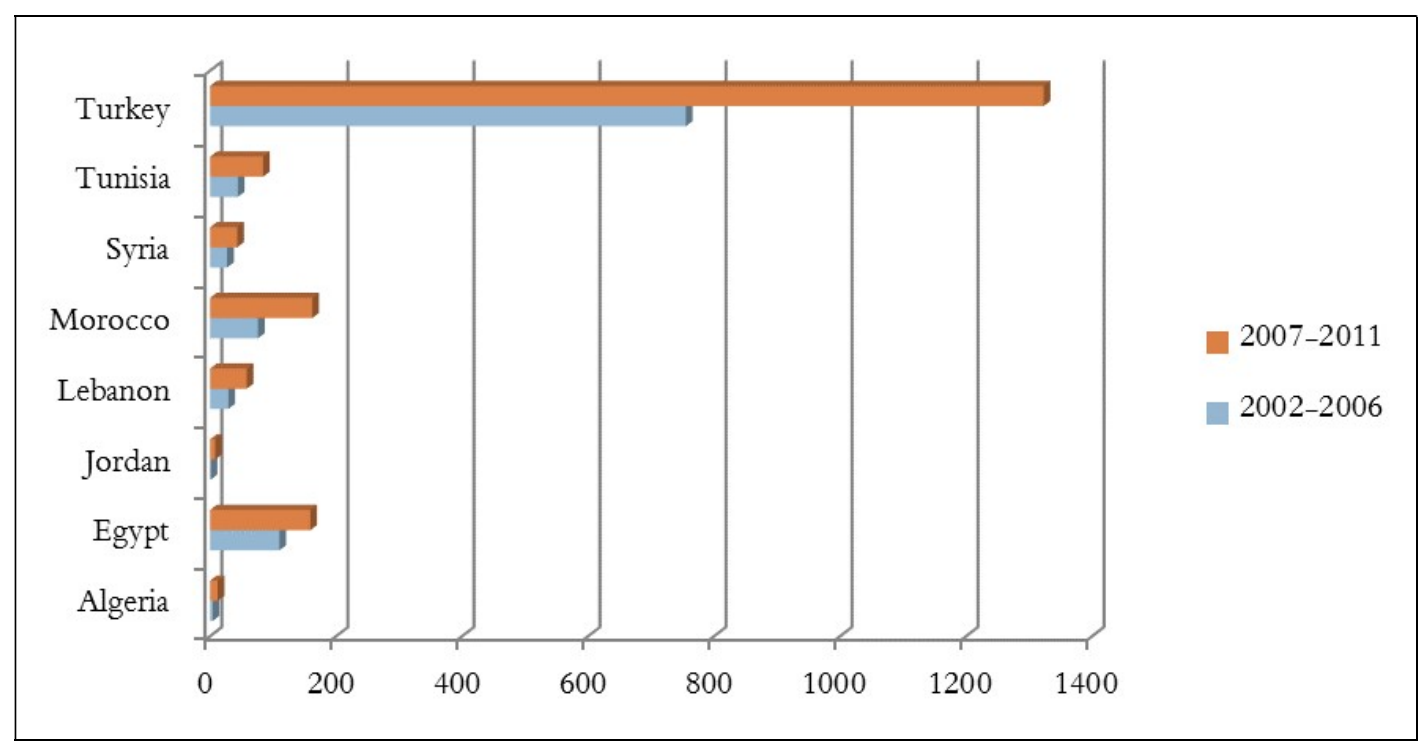

Source: Authors' calculations

It can be observed in Figure 9 that the number of notifications is increasing in recent years in all the MPCs considered. Then, if that trend continues, a further increase in notifications could be expected in the following years. The observed increment can be probably attributed to the rise in notifications for products found to be unsuitable for consumption, but also, due to the increased control related to regulations and standards imposing reinforced checks for a list of products from outside the EU. As highlighted in every RASFF annual report, Turkey is one of the countries -overall in the world, not only in the MPCs group- with highest number of notifications (see RASFF, 2012).

This repeated number of notifications leads to consider a different strand to gravity models in the analysis of the trade effect of NTMs. This is the "reputation effect" analysis. In fact, it can be argued that a higher number of registered notifications on a country exports to a certain destination market can affect the way the system of notifications considers future exports. Then, reputation is defined as the impact of previous border notifications on current ones. This would be the basic notion of reputation effect. To our best knowledge, there is only one study in the literature that has focused on the effect of reputation on developing countries exports' (Jouanjean et al., 2012) and this has been applied to the US food imports. Another

\footnotetext{
${ }^{28}$ Chapters from 01 to 22 at HS2. Source : Extracted from Garcia-Alvarez-Coque et al. (forthcoming).
} 
Chapter 5 Exploring EU food safety notifications on agro-food imports: Are Mediterranean Partner Countries discriminated?

article, Baylis et al., (2010) considered EU fish imports and explored whether SPS measures were influenced by trade protection but without testing past behavior on food border controls

We aim to explore the hypothesis that sellers' reputation -which is built on past history of notifications- affects current decisions on EU current notifications. Repeated notifications affect directly producers and the whole supply chain and may lead to additional costs in developing countries. Indeed, testing the compliance of a product with the EU standards involves costs at the expense of the exporter. Increasing costs and border rejection of products will put the country's reputation at stake. This would support the need for acrossthe-board policies in the exporting countries that improve quality and hence reputation, rather than just concentrating in fixing short-term problems occurring in specific food safety problems.

Some products can be considered more sensitive in terms of food safety than others. Seafood and fruits and vegetables seem to be the most sensitive compared to other exported products based on the large number of notifications registered (RASFF, 2012).

In this paper, we follow the reputation effects defined in Jouanjean et al. (2012), with some adjustments. Reputation includes products, sectors, countries and regions that are exposed to a higher likelihood of being more and more notified by the importer.

- Product reputation means the existence of a correlation between the number of notifications for a given product from a country in a certain year (hereinafter "product-country-year") and the number of notifications affecting the product from the same country in the previous year.

- Sector reputation of a country means that a correlation exists between the number of notifications affecting a given product-country-year and the number of notifications affecting products from the same sector (defined as those in the same HS2 chapter)-country in the previous year.

- Country reputation means a correlation between the number of notifications affecting a given product-country-year and the total number of notifications affecting the products-country combinations in the previous year.

We assume that the three previous reputation effects are positive, and label them as hypotheses H1, H2 and H3, respectively. They mean that at each year ( $\mathrm{t})$, the EU authorities may implement NTMs based on updated criteria on risk assessment, but also influenced by the past. Hence, we will examine if the product notifications of the year $(\mathrm{t}-1)$ could raise the notifications of the year $(t)$. This is the reputation effect that can be associated with the product itself, with the sector or with the country of origin, according to the three previous 
Chapter 5 Exploring EU food safety notifications on agro-food imports: Are Mediterranean Partner Countries discriminated?

definitions. We will also expand the geographical coverage by considering a reputation effect for a given region. Besides, additional hypotheses regarding the reputation effects are explored:

H4: Countries with more experience exporting food to the EU tend to present fewer notifications. This would be caused by the general learning-by-doing effect that appears in trade liberalization literature. In particular, for MPCs, this hypothesis would hold due to the traditional trade flows and the history of trade agreements with the EU.

- H5: Import notifications are related to GDP per capita. We take GDP per capita as a measure of economic development and capacity of the exporting country to face NTMs. We expect the more developed the country is, the number of notifications is fewer.

- H6: A positive relationship exists between the number of notifications and the import value from selected countries in the previous year. We expect that larger imports would involve a higher number of notifications, showing a protectionist behavior.

- H7: Some sectors can be more affected by food notifications than others. In particular, we wonder if Mediterranean products such as fruits, vegetables, and their preparations (respectively HS chapters 08,07 and 20) are favored or discriminated by the application of food safety measures at the EU border.

\subsection{Data and methodology}

Our empirical analysis of used data from RASFF selects notifications registered by the EU on shipments from the 20 top developing agricultural exporters to the EU. These notifications belong to the period between 2000 and 2012. In addition to the selected top exporters, all MPCs were considered, except for Palestine, in order to assess specifically the impact of NTMs on the agro-food Euro-Mediterranean trade. Thus, eight MPCs were included in the sample: Algeria, Egypt, Israel, Jordan, Lebanon, Morocco, Syria, Tunisia and Turkey. As we aim at studying the specific case of Mediterranean countries, a "region" reputation effect was also tested for this group.

We gathered the RASFF notifications of agro-food products in the period, aiming at classifying every notification according to the HS nomenclature. ${ }^{29}$ To do so, we developed an

\footnotetext{
${ }^{29}$ Finally, every notification was classified under one chapter between HS 01 and HS23. The HS system is an internationally standardized nomenclature for the description, classification and coding of goods. It is developed and maintained by the World Customs Organization (WCO).
} 
Chapter 5 Exploring EU food safety notifications on agro-food imports: Are Mediterranean Partner Countries discriminated?

algorithm to classify these notifications according to the product (at the four-digit HS level), sector, country and region. Moreover, the notifications database was extended to allow for economic variables, e.g. import value and GDP per capita. After all this process, the database constitutes of 5,421 observations representing the number of notifications registered by the EU during the period between 2000 and 2012, for 20 exporters to the EU. All variables used for the analysis are summarized in Table 13.

It is worth noting that the average count of notifications (1.807) is presenting a high variance on the order of 7.238. Moreover, all explanatory variables presented in Table 13 show a lower mean than their variances. This confirms the presence of over-dispersion phenomenon in the data.

Table 13. Description of independent variables ${ }^{30}$.

\begin{tabular}{clcccc}
\hline Variable & \multicolumn{1}{c}{ Description } & Min. & Max. & Mean & $\begin{array}{c}\text { Std. } \\
\text { dev }\end{array}$ \\
\hline$N_{i j(t-1)}$ & $\begin{array}{l}\text { Notifications of product (i) } \\
\text { from country (j) in lagged year } \\
(\mathrm{t}-1)\end{array}$ & 0 & 170 & 1.807 & 7.238 \\
\hline$N_{I j(t-1)}$ & $\begin{array}{l}\text { Notifications of sector (I) from } \\
\text { country (j) in lagged year (t-1) }\end{array}$ & 0 & 268 & 9.384 & 25.670 \\
\hline \multirow{2}{*}{$N_{i /(t-1)}$} & $\begin{array}{l}\text { Notifications of all products (i) } \\
\text { from country (j) in lagged year } \\
(\mathrm{t}-1)\end{array}$ & 0 & 375 & 75.1 & 82.780 \\
\hline \multirow{2}{*}{$\begin{array}{l}\text { Log import in thousand euros } \\
\text { of product (i) from country (j) } \\
\text { in lagged year (t-1) }\end{array}$} & 0 & 1335,342 & 30,313 & 84,031 \\
\hline$L n G D P p c_{j i}$ & $\begin{array}{l}\text { Ln per capita GDP of country } \\
\text { (j) in year (t) }\end{array}$ & 6,089 & 10,350 & 8,075 & 0,9064 \\
\hline
\end{tabular}

As they appear in the databases, notifications are non-negative integers. To better fit the effect of covariates that can explain the dependent variable, count data models will be used. Modeling count variables is a common quantitative practice in social sciences (Cameron and Trivedi, 2013; Zeileis et al., 2008).

Suppose $N_{i j t}$ are independent count data observations of notifications in product " $i$ " imported from country " $j$ " at year " $t$ " on the integers $N_{i j t}=0,1,2, \ldots$ with a count data distribution $f\left(\mathrm{~N}_{\mathrm{ijt}} \mid \mu\right)$ with an unknown parameter $\mu$. The following empirical model gives the expected notification count:

\footnotetext{
${ }^{30}$ To simplify the rest of variables has been omitted for reasons of space.
} 
Chapter 5 Exploring EU food safety notifications on agro-food imports: Are Mediterranean Partner Countries discriminated?

$$
\begin{aligned}
E\left[N_{i j t} \mid \mu\right]= & \exp \left\{\beta o+\left(\beta 1+\beta{ }^{\prime} 1 Z_{M}\right) N_{i j t-1}+\left(\beta 2+\beta{ }^{\prime} 2 Z_{M}\right) N_{I j t-1}+\left(\beta 3+\beta{ }^{\prime} 3 Z_{M}\right) N_{J t-1}+\right. \\
& \left(\beta 4+\beta{ }^{\prime} 4 Z_{M}\right) \text { Imports }_{i j t-1}+\left(\beta 5+\beta{ }^{\prime}{ } Z_{M}\right) \ln G D P p c_{j t}+\beta{ }^{\prime}{ }_{6} Z_{M}+\text { other fixed effects }
\end{aligned}
$$

Where $E\left[\mathrm{~N}_{\mathrm{ijt}} \mid \mu\right]$ is the mean of the count of food notifications conditional on the matrix of explanatory variables, which are detailed in Table 13 and summarized as follows:

$N_{i, j t-1}$ are the product notifications, where $i$ products are represented at four-digit HS level; $N_{I j t-1}$ are the sector notifications, where HS sectors are represented at two digits, I $=1, \ldots .$. 23 , covering agricultural products; $N_{J t-1}$ are the total exporting country's notifications, with J corresponding to each of the countries indicated above; imports (Imports Ijit-1 $_{\text {) }}$ are defined in terms of value and GDP per capita is expressed in log terms. To take account for risks associated to specific sectors a fixed effect is included for every trade chapter at the two-digit level of the HS. We also explicitly tested the differential effects on counts for exporters belonging to the Mediterranean region by including a dummy variable $Z_{M}$ that takes a value 1 when the corresponding import flow is originated in a MPC; this dummy can help to validate if there is a fixed effect for MPCs. Besides, the interaction coefficients $\beta$ ' $h, \mathrm{~h}=1, \ldots, 6$, measure the specific change in product, sector, country reputations, import and GDP per capita effects due to an export originated in a MPC.

As for the data generating process $f(\mathrm{Nijt} \mid \mu)$, we considered that the Poisson distribution for counting data poses limitations to deal with over-dispersed data sets (Cameron and Trivedi, 2013) as is the case of the dataset used in this paper. Also, by examining our panel data, a majority of our agro-food trade notifications are found to display zero values. In this context, we explore count data models where the dependent variable is discrete and a distribution comes applied at non-negative integer values. To overcome these limitations, Negative Binomial (NB) and Zero Inflated Negative Binomial models (ZINB) were chosen, as discussed below.

A problem appears in our case because of the existence of a large number of zeros in the notification counting. Although both the Poisson model and the NB regression models can, unlike the log-normal model, technically deal with zeros, they are not well suited to handle the situation in which the number of observed zeros exceeds the number of zeros 
Chapter 5 Exploring EU food safety notifications on agro-food imports: Are Mediterranean Partner Countries discriminated?

predicted by the model. The most important problem caused by excessive zeros in the data stems from the fact that two different processes can produce zero notifications. The first is the full compliance of an export to the EU food control, which is reflected by inexistence of food notifications. The second process is the absence of exports to the EU, what can be due to structural factors depending on resources, distances, preferences and specialization. In this case, food notifications do not appear because the probability of trade is zero, and notification cannot apply to the corresponding product and partner. The possibility of such double process leads to test a ZINB model (Greene, 1994) that considers the existence of two latent groups within the sample of exporting countries: a group having strictly zero counts and a group having a non-zero probability of having counts other than zero. Therefore, the estimation process of the ZINB contains two parts. The first part includes a probit regression of the probability that there is not any count of food notifications at all. The second part contains a NB analysis of the notification count for the group that has a non-zero probability of trade. Then a zero-inflated model with extra proportion of zeros $p$ is defined by the following probability density function:

$$
\begin{gathered}
\operatorname{Prob}\left(N=N_{i j k t} \mid \mu\right) \\
\begin{cases}p+(1-p) f\left(N_{i j k t}=0 \mid \mu\right) & \text { If } N_{i j k t}=0 \\
(1-p) f\left(N_{i j k t} \mid \mu\right) & \text { If } N_{i j k t}>0\end{cases}
\end{gathered}
$$

Eq. (2)

Where we consider a negative binomial distribution for $f(\mathrm{Nijt} \mid \mu)$. The present contribution has included, in the probit part, variables that influence the probability of appearance of no counts: product, sector and country reputations at year $\mathrm{t}-1$; and a dummy variable $t .1$ that takes a value of one when there was import of the corresponding product in year $\mathrm{t}-1$. This last variable is assumed to affect the probability of zero counts but remains uncorrelated with the number of notifications at year t. Maximum likelihood estimation of the parameters of the ZINB model is documented in Cameron and Trivedi (2010). With these three possible models (Poisson, NB and ZINB), we carried out the estimations. Their results are presented in the next section.

\subsection{Results and discussion}

As an initial exploratory analysis, a correlation chart was made showing the influence of 
Chapter 5 Exploring EU food safety notifications on agro-food imports: Are Mediterranean Partner Countries discriminated?

lagged notifications on the current ones for the same product in Figure 10. It seems to support $\mathrm{H} 1$, so that reputation matters in EU border controls. These results would be consistent to what was found by Jouanjean et al (2012) for the US import refusals.

Figure 11 shows the effect of development levels (measured in terms of GDP per capita) on present notifications (H5). It illustrates a negative relationship between the two variables, hence suggesting that countries with higher GDP per capita tend to have lower notifications.

Figure 10. Product reputation. A correlation analysis of one-year lagged and current notifications

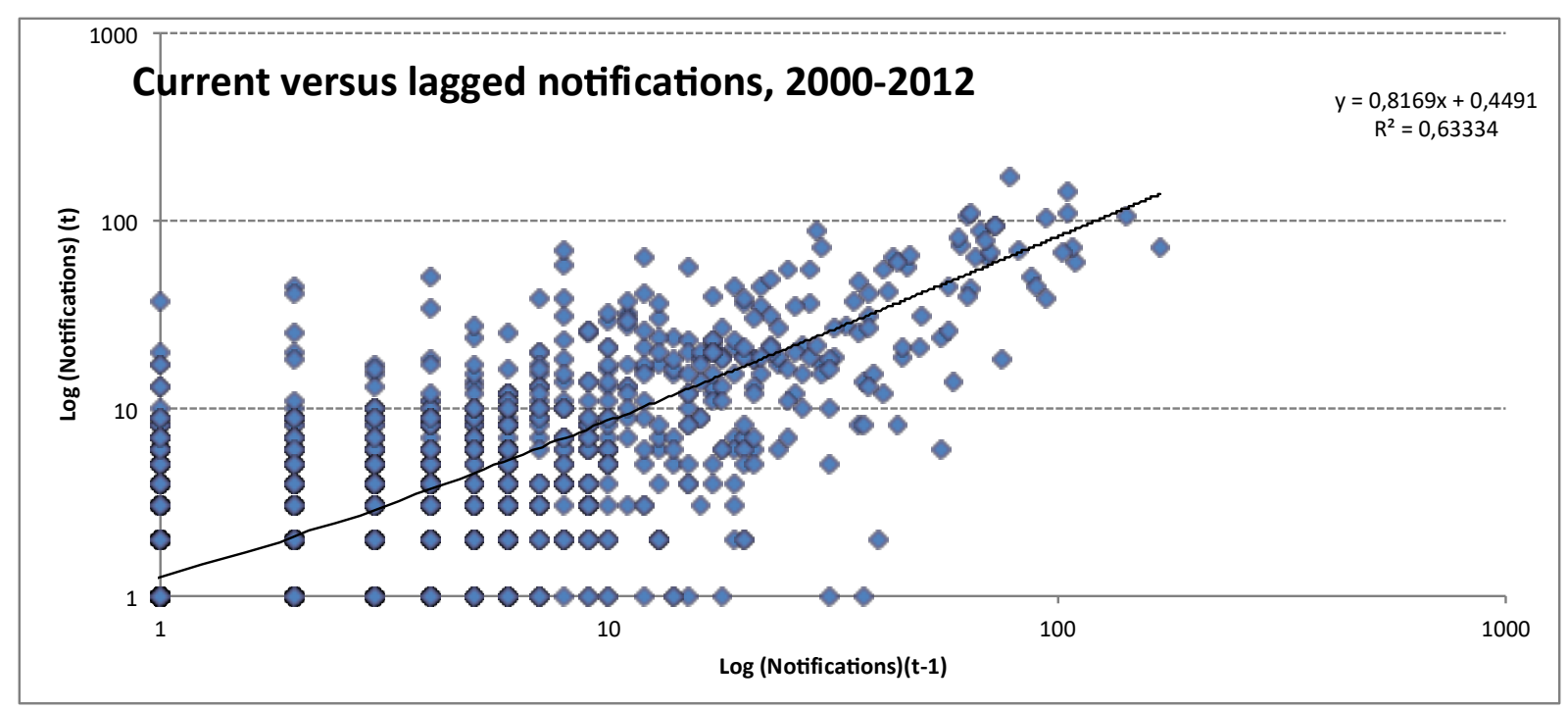

Source: Authors' calculations 
Chapter 5 Exploring EU food safety notifications on agro-food imports: Are Mediterranean Partner Countries discriminated?

Figure 11. Relationship between the single average of notifications and their GDP per capita

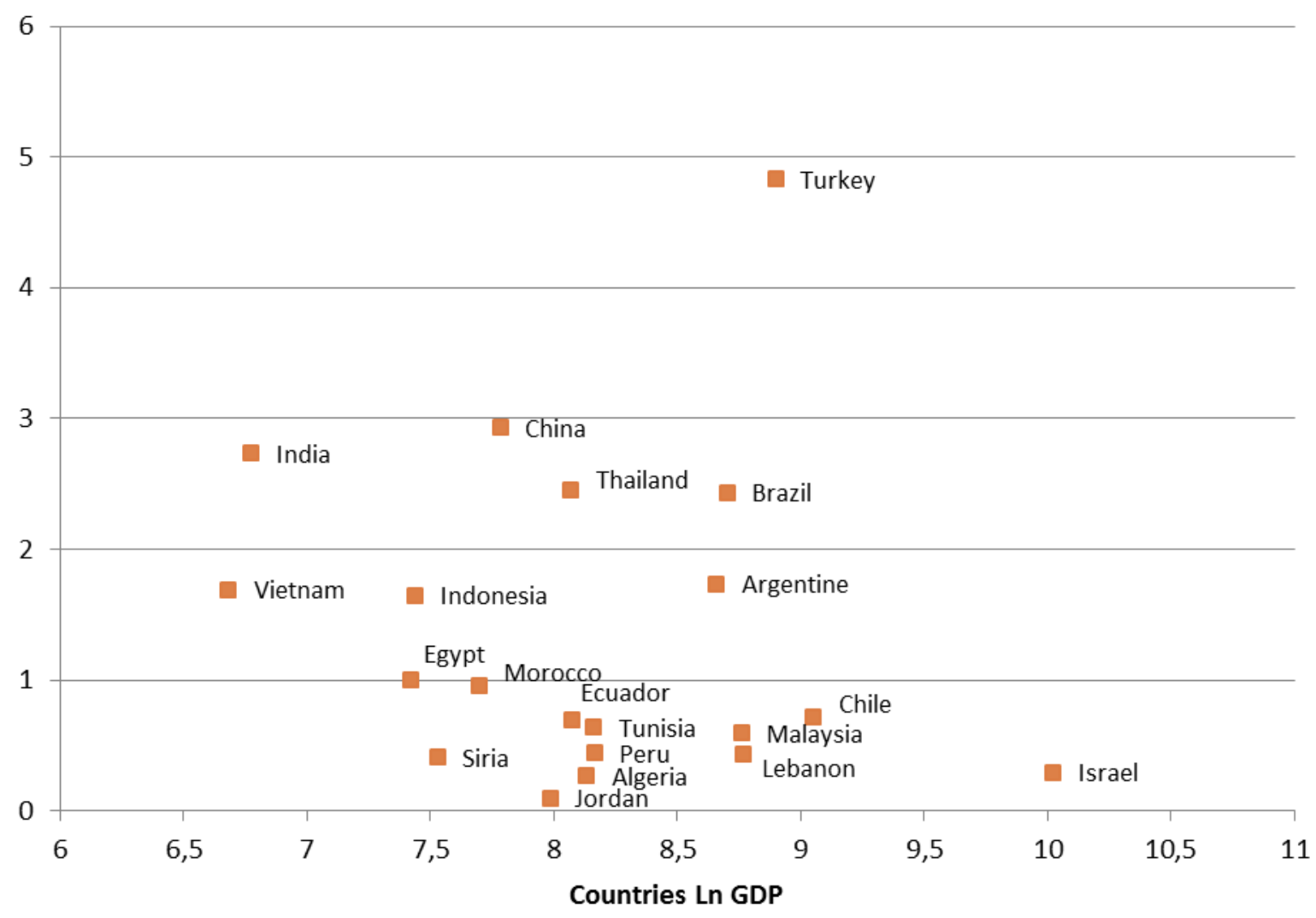

Source: Authors' calculations

Turning now to the count data models' estimates, Table 14 presents the results of the estimation. At first sight, the poor general performance of the Poisson model fits with the findings of the literature regarding its lack of validity with over dispersed data. It can also be seen through the significantly higher log-Likelihood rate and AIC and BIC indicators compared to the other models tested.

For the NB and ZINB models, the model selection indicators AIC and BIC apparently favor the selection of the ZINB model against the NB version. However, the Vuong test, suitable to compare both kinds of models (Vuong, 1989), indicates that the NB model provides a better fit to the data than the ZINB model. If we depict the different counts of observed notifications and of those predicted by both models (Figure 12) we find that the NB model predicts a percentage of different counts that it is closer to the observed curve than the ZINB model. So we could accept as well the adequacy of the NB model. As model comparison criteria do not lead to unequivocal conclusions, we will make reference to both models' results in the next paragraphs. 
Chapter 5 Exploring EU food safety notifications on agro-food imports: Are Mediterranean

Partner Countries discriminated?

Table 14. Statistical models: estimated parameters and models' fit indicators

\begin{tabular}{|c|c|c|c|}
\hline & Poisson & NB & ZINB \\
\hline (Intercept) & $0.194(0.296)$ & $-0.865(0.135)^{* * *}$ & $-0.024(0.140)$ \\
\hline$N_{i j(t-1)}$ & $0.780(0.013)^{* * *}$ & $0.160(0.005)^{* * *}$ & $0.092(0.007)^{* * *}$ \\
\hline Med & $-0.455(0.381)$ & $-0.149(0.179)$ & $-0.026(0.184)$ \\
\hline$N_{I J(t-1)}$ & $-0.012(0.005)^{*}$ & $-0.001(0.002)$ & $-0.003(0.002)$ \\
\hline$N_{i j(t-1)}$ & $0.002(0.001)^{*}$ & $0.004(0.000)^{* * *}$ & $0.003(0.000)^{* * *}$ \\
\hline $\log G D P p c_{j t}$ & $-0.002(0.001)$ & $-0.002(0.001)^{* * *}$ & $-0.003(0.001)^{* * *}$ \\
\hline lmports $_{i j[t-1]}$ & $0.000(0.000)^{* *}$ & $0.000(0.000)^{* * *}$ & $0.000(0.000)^{* * *}$ \\
\hline$N_{i j(t-1)}: M e d$ & $0.159(0.021)^{* * *}$ & $-0.036(0.008)^{* * *}$ & $-0.024(0.013)$ \\
\hline$N_{I j(t-1)}: M e d$ & $0.018(0.007)^{* *}$ & $0.005(0.003)$ & $0.005(0.002)^{*}$ \\
\hline$N_{i j(t-1)} \cdot M e d$ & $-0.003(0.002)$ & $-0.002(0.001)$ & $-0.001(0.001)$ \\
\hline $\operatorname{LnGDPpc_{jt}:Med}$ & $0.003(0.003)$ & $0.001(0.002)$ & $0.000(0.002)$ \\
\hline Imports $_{i \bar{f}(t-1)^{1}}$ Med & $0.000(0.000)$ & $0.000(0.000)$ & $0.000(0.000)$ \\
\hline$f_{I}$ & Yes & yes & yes \\
\hline Zero model : (Intercept) & & & $0.421(0.116)^{* * *}$ \\
\hline t.1 & & & $-0.132(0.115)$ \\
\hline$N_{i j(t-1)}$ & & & $-0.852(0.096)^{* * *}$ \\
\hline$N_{I j(t-1)}$ & & & $-0.003(0.002)$ \\
\hline$N_{i j(t-1)}$ & & & $-0.001(0.000)$ \\
\hline Num. obs. & 5420 & 5420 & 5420 \\
\hline $\mathrm{AIC}$ & 31980.592 & 14294.438 & 13869.626 \\
\hline $\mathrm{BIC}$ & 32191.723 & 14505.569 & 14113.75 \\
\hline Log Likelihood & -15958.296 & -7115.219 & -6897.813 \\
\hline Deviance & 114535.968 & 4044.840 & \\
\hline Overdispersion $(\alpha)$ & & $9.2287^{* * *}$ & \\
\hline Vuong Test & & $-12.150^{* * *}(\mathrm{NB}>\mathrm{ZINB})$ & \\
\hline
\end{tabular}

Note: ZINB consists of two parts. The first part is a negative binomial regression of probability. The second contains a probit regression of the probability. ${ }^{* * *} \mathrm{p}<0.001,{ }^{* *} \mathrm{p}<0.01,{ }^{*} \mathrm{p}<0.05$. Standard errors are provided in brackets. For overdispersion, the alpha value is displayed, for the Vuong test the z-score.

Source: Authors' calculations. All models are estimated using R-language

Coefficients in Table 14 can be interpreted as the marginal effects of increasing the levels on the right hand side of equation (1). For covariates expressed in levels, coefficients mean the percent change in the food notification count for product $i$ from country $j$, due to a change in one unit of the studied covariate. When the covariate is expressed in log terms, such as it happens with GDP per capita, the coefficient is an elasticity measuring the percent change in the food notification count related to one per cent change in the explanatory variable. Fixed effects and constant provide the food notifications given by the exponential of the studied fixed effect or constant. In addition, in this exercise we can see how the general 
Chapter 5 Exploring EU food safety notifications on agro-food imports: Are Mediterranean Partner Countries discriminated?

levels of the different covariates may increase or decrease by measuring the coefficients of interaction variables with a dummy that refers to a MPC.

Our empirical results show that notifications registred in year $t$ are largely affected by those claimed in previous periods. Product reputation on $\mathrm{N}_{\mathrm{ij}(\mathrm{t}-1)}$ has the expected positive sign in both the NB and ZINB models. This coefficient is statistically significant at $1 \%$ significance level indicating that increase in one unit in lagged notifications $\mathrm{N}_{\mathrm{ij}(\mathrm{t}-1)}$ would increase the number of expected notifications $\mathrm{N}_{\mathrm{ij} \mathrm{t}}$ by $16 \%$ in the NB model and $9 \%$ in the ZINB model. These results confirm H1, so that the past history of notifications issued at the EU borders affects the number of notifications for same product-country in the next year.

As for $\mathrm{H} 2$ (sector reputation), the corresponding coefficients were not found significant, suggesting that the notion of collective reputation applied to a sector $I$ has no influence on the food notifications for the product $i$ belonging to that sector in the next year.

Confirming H3, the impact of the country reputation was found to be statiscally significant and positive, although small in value. Thus, the registred notifications in year $\mathrm{t}$ applied to the products are affected by the collective reputation of the exporter involved in the trade flow, so one food notification in country $J$ adds to the product notification count $0.4 \%$ (NB) and $0.3 \%$ (ZINB).

As regards to the level of development of partner countries tested in H5, regressions show that GDP influences the number of notifications. Indeed, the GDP is statiscally significant at $1 \%$ significance level which means that the EU rejections depend on exporter's characteritics correlated with GDP per capita of the countries (infrastructure, human capital, etc). This finding is consistent with the regression curve drawn in Figure 11 and also in line with our expectations in H5. The GDP per capita has a negative coefficient in both NB and ZINB version (with elasticity of -0.2 and -0.3 , respectively). The level of development of national standards infrastructure is relevant to the determination of import notifications. It is due to the higher quality of exported products in more developed countries and the better adoption of new technologies. It is not surprising that countries with higher GDP accomplish more successfully the required standards by the EU.

Regarding the lagged import value (H6), this has a positive and 1\% statistically significant coefficient. This findindg suggests that import value is a relevant determinant of the total number of food notifications. The positive coefficient of this variable means that the increase of imports from an exporter, independently of its history of compliance with EU 
Chapter 5 Exploring EU food safety notifications on agro-food imports: Are Mediterranean Partner Countries discriminated?

standards, is accompanied by a stricter control in the borders. This could suggest a EU protectionist behavior, as it is normal that when import value increases, though it is normal that the border controls become more intensive and tend to increase their frequency as imports increase, generating an increase in food notifications.

Figure 12. Different counts of observed notification and those predicted by both models

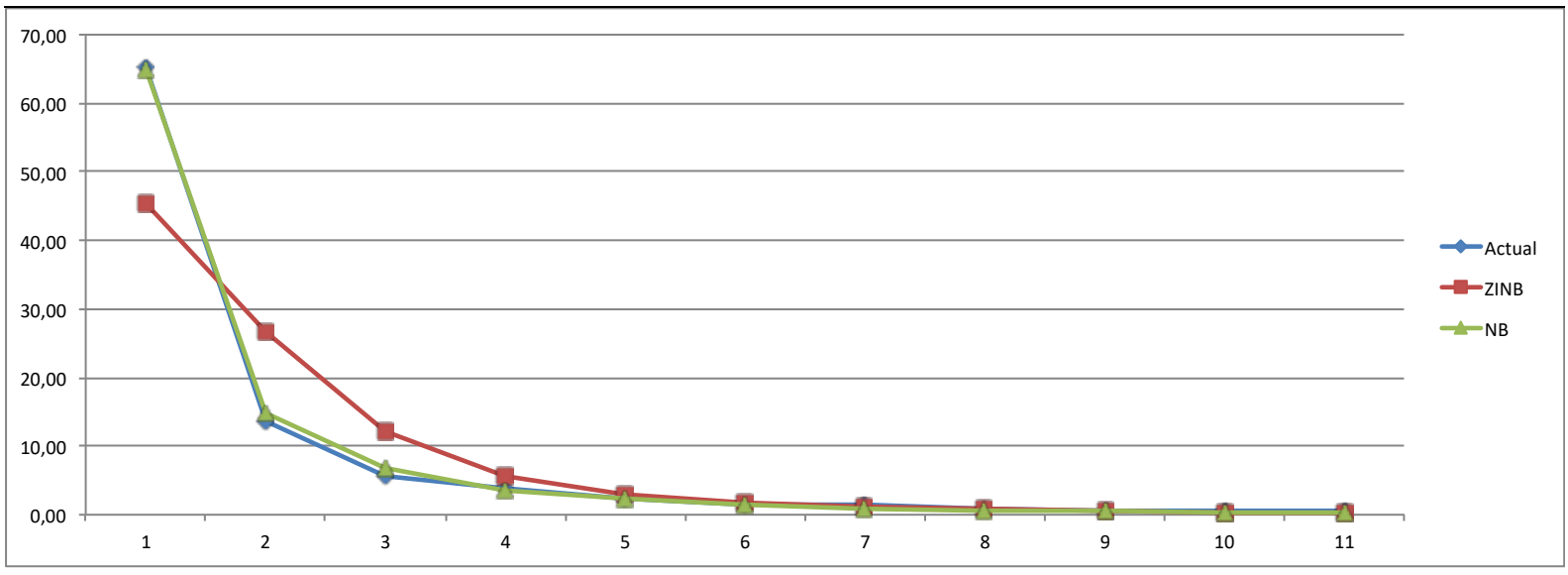

Source: Authors' calculations

After these general findings, it is time to look at the differential effect for MPCs as analysed in H4 and H7. First of all, as we considered sectoral fixed effects as covariates whose parameters are not shown in the Table 14 for space reasons- we found a significant a positive coefficiente for HS chapters 03 (fish product) and 02 (meat products) indicating a higher propensity to issue notifications for these two chapters. Also, we found a significative negative coefficient for HS chapters 15 (animal and vegetable oils), 18 (cocoa) and 22 (beverages), with the opposite meaning. Among these cases, chapters 03 and 15 are of export interest for MPCs. However, the parameters for HS chapters 07, 08 and 20, which include vegetables and fruits and their preparations, did not result significant in the models estimated. Hence, we did not find a sector bias against of favouring these products of crucial interest for Mediterranean exporters to the EU.

As for the interaction variables including the MPC regional effect, they were not found to be significant in neither the NB nor the ZINB model for country reputation, import level and $\log$ GDP per capita suggesting the absence of a Mediterranean bias with respect to how the characteristics of the exporting country and its exports affect the propensity of the EU to release food notifications. This is supported by the non-significancy of the Mediterranean fixed effect parameter. Mediterranean interactions with product notifications were found 
Chapter 5 Exploring EU food safety notifications on agro-food imports: Are Mediterranean Partner Countries discriminated?

significant in the NB model, with negative sign. It suggests that the marginal percent effect of increasing in one unit the notification count from a MPC would reduce the average expected count of notifications for products concerned by 3.6\%. Mediterranean countries' sector reputation was found significant at 5\% in the ZINB estimated model, although the value of the effect is quite marginal (a slight $0.5 \%$ increase in the counts of product notification in year $\mathrm{t}$ resulting of one more notification in the same sector from a MPC in year ( $t-1)$.

\subsection{Concluding remarks}

This study aims at assessing if the reputation effects can affect the implementation of NTMs, considering RASFF notifications at the EU border. While notifications are influenced by specific SPS and TBT problems, however, it may happen that past notifications have an influence on present restrictiveness of NTMs. Four types of reputation effects were considered, namely product, sector, country and region reputations.

Our empirical findings suggest that the EU notifications are affected firstly by the own reputation of a product and the country reputation, with relatively stronger effect of the reputation built at the product level. Nevertheless, reputation of a product does not affect in the sector level. Notifications are also affected by the import value suggesting a possible protectionist behavior. Implementation of NTMs by the EU vary according the per capita GDP of the exporter, suggesting that investment in infrastructure and human capacities favor the integration of agro-exporting firms in the global value chains to comply with EU requirements regarding the quality of imported products.

These results suggest that, apart from specific problems related to given products, it is worth noting that product and country reputation affect strongly the notification count. Thus, export quality policies have to be built at a country or wider level. It is strongly recommended to involve the developing country stakeholders in NTMs-setting process through international organizations and bilateral discussions to get more harmonization between European standards and their agri-food suppliers, including partnership agreements between the EU and developing countries. Our findings give a strong base that reputation builds on across-theboard efforts to improve quality compliance in one zone or sector, beyond the problems of a specific product.

Our results show that there is no sign of an anti or pro Mediterranean bias in the way food safety policy is implemented at the EU borders. This does not mean that the Mediterranean countries are out of the RASFF system and actually they are affected by the 
Chapter 5 Exploring EU food safety notifications on agro-food imports: Are Mediterranean Partner Countries discriminated?

implementation of EU safety standards as occurs in other partners in the world. Instead, what is reflected in our models is that there is no sign of protectionist behaviour by the EU against Mediterranean exporters, even when their export specialization competes with Southern European production, namely on fruits, vegetables and its preparations. On the other hand, historical partnership and the geographical proximity could reflect in a better treatment as might be suggested by the coefficient of the NB for the Mediterranean product reputation. 
Chapter 5 Exploring EU food safety notifications on agro-food imports: Are Mediterranean

Partner Countries discriminated?

\section{References}

Anders, S.M., \& Caswell, J. (2009). Standards as barriers versus standards as catalysts: Assessing the impact of HACCP Implementation on U.S. Seafood imports. American Journal of Agricultural Economics, 91(2), 310-321.

Baylis, K., Nogueira, L., \& Pace, K. (2010). Food import refusals: Evidence from the European Union. American Journal of Agricultural Economics, 93(2), 566-572.

Beghin, J.C., \& Bureau, J.C. (2001). Quantitative policy analysis of sanitary, phytosanitary, and technical barriers to trade. Economie Internationale, 3, 107-130.

Cadot, O., Malouche, M., \& Sáez, S. (2012). Streamlining non-tariff measures: A toolkit for policy makers. World Bank Publications.

Cameron, A. C., \& Trivedi, P. K. (2010). Microeconometrics using Stata: Revised edition.

Cameron, A.C., \& Trivedi, P. K. (2013). Regression analysis of count data. Cambridge University Press.

Deardorff, R., \& Stern, N. (1997). Measurement of non-tariff barriers. OECD, Economics Department : Working Papers, 179.

Disdier, A.C., Fontagné, L., \& Cadot, O. (2014). North-South standards harmonization and international trade. The World Bank Economic Review, 29(2), 327-352.

Essaji, A., (2008). Technical regulations and specialization in international trade. Journal of International Economics, 76(2), 166-76.

Tudela-Marco, L., Garcia-Alvarez-Coque, J.M., \& Martinez-Gomez, V. (2014). Are non-tariff measures a substitute for tariffs in agricultural trade? Recent evidence from southern Mediterranean countries. Outlook On Agriculture, 43(4), 235-240.

Garcia Martínez, M., Poole, N.D., Skinner, C. (2006). Food safety performance in European Union accession countries: Benchmarking the fresh produce import sector in Hungary. Agribusiness: An International Journal, 22(1), 69-89.

Grazia, C., Hammoudi, A., \& Malorgio, G. (2009). Regolamentaziones della qualità sanitaria degli alimenti e acesso dei Paesi Della riva Sud del Mediterraneo ai Mercali europei: Un analisi empirica. Comunicazione XLVI Convegno di Studi, SIDEA, Piacenza, 16-19.

Greene, W. (1994). Accounting for excess zeros and sample selection in Poisson and negative binomial regression models. New York: New York University, Leonard N. Stern School of Business. 
Chapter 5 Exploring EU food safety notifications on agro-food imports: Are Mediterranean

Partner Countries discriminated?

Henson, S., \& Jaffee, S. (2006). A Strategic Perspective on the Impact of Food Safety Standards on Developing Countries. Presented paper at the International Association of Agricultural Economists Conference, Gold Coast, Australia.

Jaud, M., Cadot, O., Suwa-Eisenmann, A. (2013). Do food scares explain supplier concentration? An analysis of EU agri-food imports. European Review of Agricultural Economics, 40(5), 837-890.

Jouanjean, M.A., Maur, J.C., \& Shepherd, B. (2012). Reputation matters: Spillover effects in the enforcement of US SPS measures. Non-tariff measures. In: A Fresh Look at Trade Policy's New Frontier. The International Bank for Reconstruction and Development/The World Bank. NW, Washington: USA.

Maertens, M., \& Swinnen, J.F.M. (2009). Trade, standards, and poverty: Evidence from Senegal. World Development, 37(1), 161-78.

Michalopoulos, C., (1999). Trade policy and market access issues for developing countries: Implications for the millenium round. World Bank Publications.

Movchan, V., (1999). Welfare costs of certification. EERC conference proceedings.

Nimenya, N., Ndimira, P., \& De Frahan, B. (2012). Tariff equivalents of non tariff measures: The case of European horticultural and fish imports from African countries. Agricultural Economics, 43(6), 635-653.

OECD, (2005). Looking beyond tariffs: The role of non-tariff barriers in world trade. OECD Trade Policy Studies.

Otsuki, T., Wilson, J.S., \& Sewadeh, M. (2001). What price precaution? European harmonisation of aflatoxin regulations and African groundnut exports. European Review of Agricultural Economics, 28(3), 263-283.

RASFF, (2012). The Rapid Alert System for Food and Feed annual report. European Commission: http://ec.europa.eu/food/safety/rasff/docs/rasff_annual_report 2012 en.pdf

Vuong, Q.H., (1989). Likelihood ratio tests for model selection and non-nested hypotheses. Econometrica: Journal of the Econometric Society, 57(2): 307-333.

Wilson, J.S., \& Otsuki, T. (2004). To spray or not to spray: Pesticides, banana exports, and food safety. Food Policy, 29(2), 131-146.

Zeileis, A., Kleiber, C., \& Jackman, S. (2008). Regression models for count data in R. Journal of Statistical Software, 27(8), 1-25. 
Food security, competitiveness and trade: The case of Tunisian agriculture 
Chapter 6. Food security, competitiveness and trade: The case of Tunisian agriculture

\section{Co-author letter}

UNIVERSITAT

POLITECNICA

DE VALĖNCIA

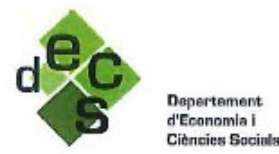

Valencia, 3 february 2017

Mr. Jose Maria Garcia-Alvarez-Coque Co-author of the publication: Food Security; Competitiveness and Trade: The case of Tunisian Agriculture, published as a chapter in the book "Food Security and Sustainability: Investment and Financing along Agro-Food Chains", Declares that he agrees with the presentation by the doctoral candidate, Ibtissem Taghouti, of this publication as part of the doctoral thesis; additionally expresses his renounce to the use of this work as part of other ddctoral thesis.

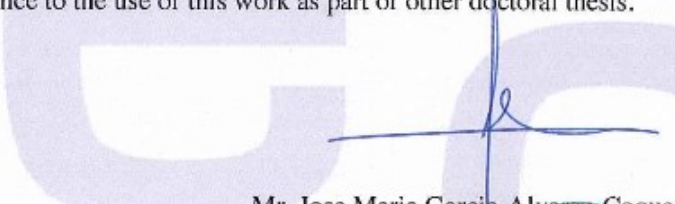

Mr. Jose Maria Garcia-Alwarez-Coque Department of Economics aif Social Sciences Universitat Politè đríta de Valènciá:

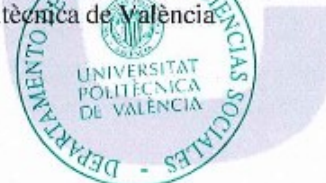

Departament d'Economia i Ciències Socials

Source: Department of Economics and Social Sciences; Dr. Jose Maria Garcia-Alvarez-Coque 
Chapter 6. Food security, competitiveness and trade: The case of Tunisian agriculture

\section{Co-author letter}

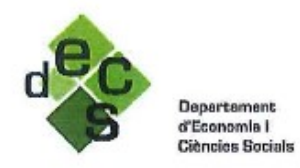

Valencia, 3 february2017

Mr. Victor Martinez-(iomez Co-author of the publication: Food Security; Competitiveness and Trade: The case of Tunisian Agriculture, published as a chapter in the book "Food Security and Sustainability: Investment and Financing along Agro-Food Chains", Declares that he agrees with the presentation by the doctoral candidate, Ibtissem Taghouti, of this publication as part of the doctoral thesis; additionally expresses his renounce to the use of this work as part of other doctoral thesis.

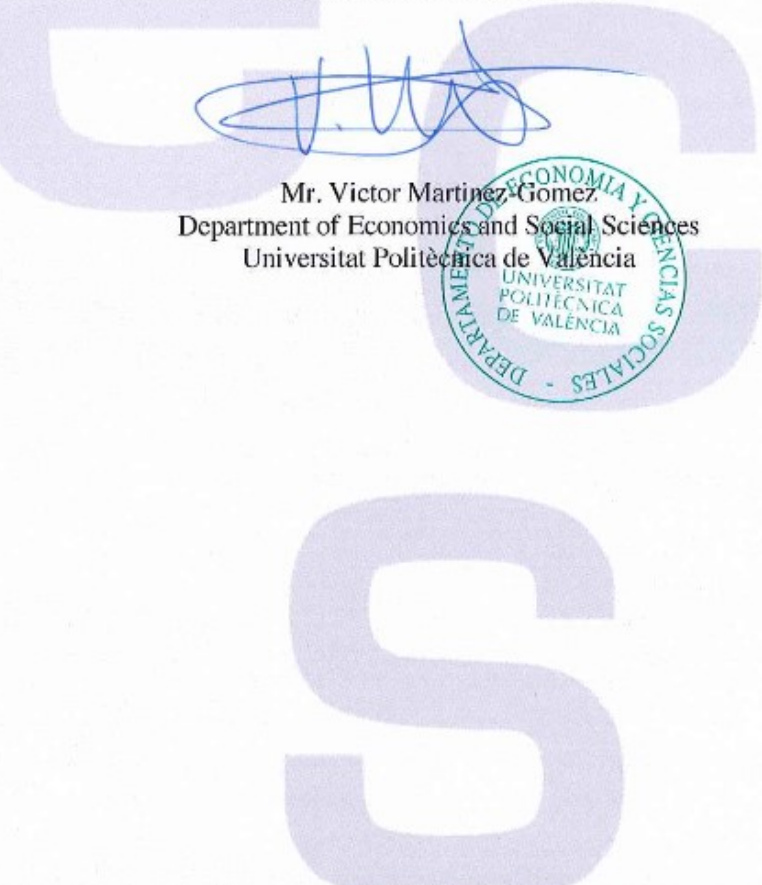

Departament d'Economia i Ciències Socials

Camí de Vora, s/n.46022 VALENCIA.Tel. 963877470. Fax.963877479.E-mail: decs@upvnet.upv.es

www. upv.es \entidades\DECS

Source: Department of Economics and Social Sciences; Dr. Victor Martinez-Gomez 
Chapter 6. Food security, competitiveness and trade: The case of Tunisian agriculture

\section{Co-author letter}
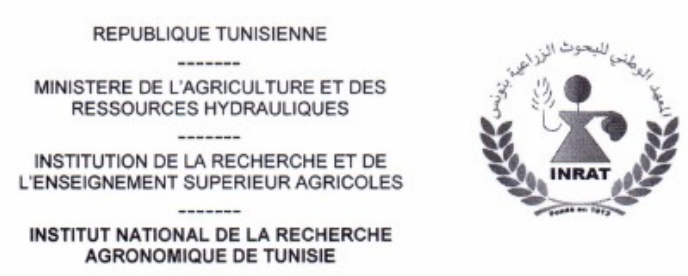
AGRONOMIQUE DE TUNISIE

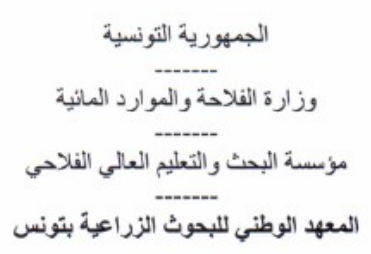

Tunis, 3 february 2017

Mr. Mohamed Elloumi Co-author of the publication: Food Security; Competitiveness and Trade: The case of Tunisian Agriculture, published as a chapter in the book "Food Security and Sustainability: Investment and Financing along Agro-Food Chains", Declares that he agrees with the presentation by the doctoral candidate, Ibtissem Taghouti, of this publication as part of the doctoral thesis; additionally expresses his renounce to the use of this work as part of other doctoral thesis.

$$
\text { Mr. Mobermed Elloumi }
$$$$
\text { Laboratoire d'Economie Rurale }
$$

Institut National de Recherche Agronomique de Tunis

Rue Hédi Karray, 2049 Ariana, Tunisie
Tél. +216 71 230-024/ 71 230-239

Tél. +216 71 230-024/71 230-239
Fax. +216 71 230-531/71 752-897
الهو الهابي كرابي، 23049 أرياية - تونس

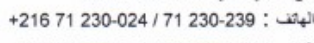

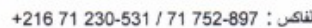

Source: Laboratoire d'Economie Rurale Institut National de la Recherche Agronomique de Tunisie (INRAT), Dr. Mohamed Elloumi 
Chapter 6. Food security, competitiveness and trade: The case of Tunisian agriculture

Food security and sustainability: Investment and financing along Agro-food chains

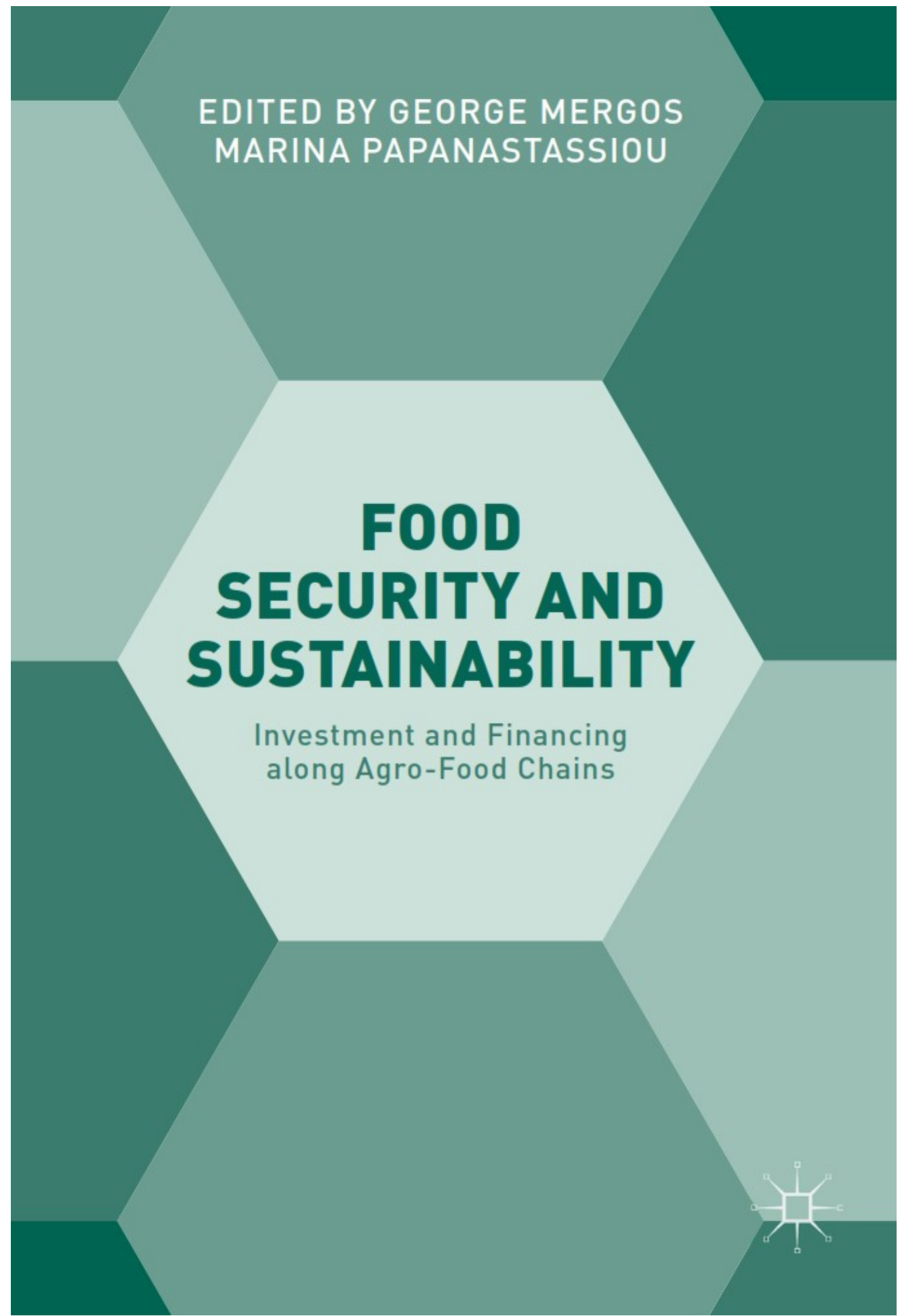


Chapter 6. Food security, competitiveness and trade: The case of Tunisian agriculture

\title{
Food security, Competitiveness and trade: The case of Tunisian agriculture $^{31}$
}

\author{
Ibtissem Taghouti $^{1}$ \\ Mohamed Elloumi ${ }^{2}$ \\ Victor Martinez-Gomez ${ }^{1}$ \\ Jose Maria Garcia Alvarez-Coque ${ }^{1}$
}

${ }^{1}$ Department of Economics and Social Sciences;

Group of International Economics and Development;

UPV-UniversitatPolitècnica de València, Spain

${ }^{2}$ Laboratoire d'Economie Rurale

Institut National de la Recherche Agronomique de Tunisie (INRAT)

12

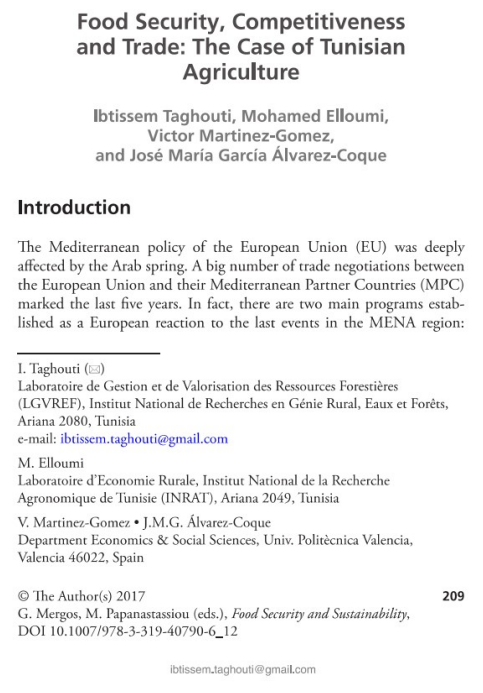

\footnotetext{
${ }^{31}$ It was published in the edited book Food security and sustainability: Investment and financing along Agrofood chains in 2017, pages 209-228. DOI : 10.1007/978-3-319-40790-6_12
} 


\title{
Chapter 6. Food security, competitiveness and trade: The case of Tunisian agriculture
}

\begin{abstract}
The purpose of this study is to provide an overview about the competitiveness of the Tunisian agri-food sector before signing the Deep and Comprehensive Free Trade Agreement with the EU. Agri-food sector plays a vital role in Tunisian economy and exports. However, the globalization of markets can influence the comparative advantage of agri-food sector enjoyed by Tunisia in exporting several Mediterranean products and increase competition. Tunisian agricultural sector's competitiveness is deeply concerned given the particular economic context in the country after the revolution and the important competition atmosphere in the Mediterranean area. Meanwhile, food security is an essential priority that cannot be compromised. Tunisia should tradeoff between two options by signing the DCFTA agreement: Developing agri-food exports in free trade area or protecting local market and the implementation of new policies to ensure food security. An analysis of the competitive advantage of the Tunisian agri-food sector reveals an important potential of exporting some agri-food staples. Recently, Tunisia is facing new challenges in exporting strategic products such as dates and olive oil, underlying the importance of adopting new business and marketing strategies, such as conditioning, packaging or prospecting new markets.
\end{abstract}

Key words: Competitiveness index; agri-food sector; trade; food security; Tunisia

\subsection{Introduction}

The Mediterranean policy of the European Union (EU) was deeply affected by the Arab spring. A big number of trade negotiations between the European Union and their Mediterranean Partner Countries (MPC) marked the last five years. In fact, there are two main programs established as a European reaction to the last events in the MENA region: the European Neighborhood Program for Agriculture and Rural Development (ENPARD), running from 2014 to 2020, and the Deep and Comprehensive Free Trade Agreements (DCFTA). These European initiatives could present an important opportunity for Mediterranean countries to deal with the existing social and trade issues. Even without mobilizing funds, the European support can be relevant to the MPC by sharing experiences and helping in capacity building. (Garcia-Alvarez-Coque and Martinez, 2016). Besides, the 
Chapter 6. Food security, competitiveness and trade: The case of Tunisian agriculture

EU is trying to refine a new Mediterranean policy adapted to each country in the Southern shore, as it would be inappropriate to understand the area as a block.

In the beginning, the DCFTA was an initiative launched by the EU to create a free trade area with Georgia, Moldova and Ukraine. In 2011, preparation sessions for negotiations were begun to implement Deep and Comprehensive Free Trade Areas with Egypt, Jordan, Morocco and Tunisia. In 2015, there was a plan to start negotiations of DCFTA with Morocco, Tunisia and Jordan. Focusing on Tunisia, the third meeting of the preparatory process for the negotiations of a DCFTA took place on 19 June 2015 in Tunis and the Tunisian Prime Minister announced that Tunisia is ready to launch the DCFTA negotiations on 13 October 2015. The DCFTA guarantees the access of associated countries to the EU internal market in selected sectors as well as ensuring to the European investors the same regulatory environment in the associated country as in Europe. Bilateral negotiations on trade liberalization in services and establishment will be integrated into the DCFTA. However, bilateral negotiation on agriculture remains open and controversial. In the Mediterranean region, the actual situation is a severe dependence on foreign supplies of food which could present an important threat to food security in the region. (Abis, 2012). Regarding the most basic staples, the northern African countries account for about $20 \%$ of world wheat imports with only $2 \%$ of world population. Indeed, all countries of North Africa are very dependent on agricultural imports with a deficiency in agri-food trade balance. In the case of Tunisia, traditional agri-food policies aimed at alleviating the import bill by exporting products with comparative advantage. While this strategy to ensure food security has been questioned (see Akesbi, 2011 for Morocco and Petit, 2015 for the region), it is still worthwhile to identify the degree of export competitiveness of Tunisian products on key markets in order to enhance food security in the country.

Trade could be a driver of prosperity for Tunisia if European efforts turn to the economic development, political stability and achieve essential goals such as food security. However, several critiques are emerging about the benefits of DCFTA to the southern economies. In this sense, the main concern is about the readiness of the Tunisian market to benefit from the DCFTA planned gains in the agri-food sector.

Against this panorama, the main objective of this chapter is to assess the competitiveness of Tunisian agri-food products in respect to the Europe and Maghreb before signing DCFTAs. In addition, this paper aims to identify and assess the main points of controversy related to the DCFTAs between the EU and Tunisia and the ways to mitigate 
Chapter 6. Food security, competitiveness and trade: The case of Tunisian agriculture

them from the Tunisian point of view, by exploring some of the issues related to the rural communities and market actors in Tunisia.

The chapter is organized as follows. After presenting a framework of the situation, the agri-food sector and trade in Tunisia and the expected advantages and costs of the DCFTA are described in section "Agri-food sector, Trade and DCFTA in Tunisia". In Section "Expected Benefits and shortcomings of the DCFTA", we present the competitiveness indicator computed and Sect. 4 shows the results of the calculations to illustrate the competitiveness of the agri-food sector in Tunisia just before signing the DCFTA. The chapter ends with some conclusions and policy implications drawn from the analysis.

\subsection{Agri-food sector, trade and DCFTA in Tunisia}

Since its independence, Tunisia has considered agriculture as a key sector for its economic development and a national priority. Nevertheless, since 1996, the agri-food sector share in the gross domestic product (GDP) has decreased sharply from about 16 to $9 \%$ in 2014 (Figure 13)

Figure 13. Agriculture value added share in Tunisia's GDP (1980-2014)

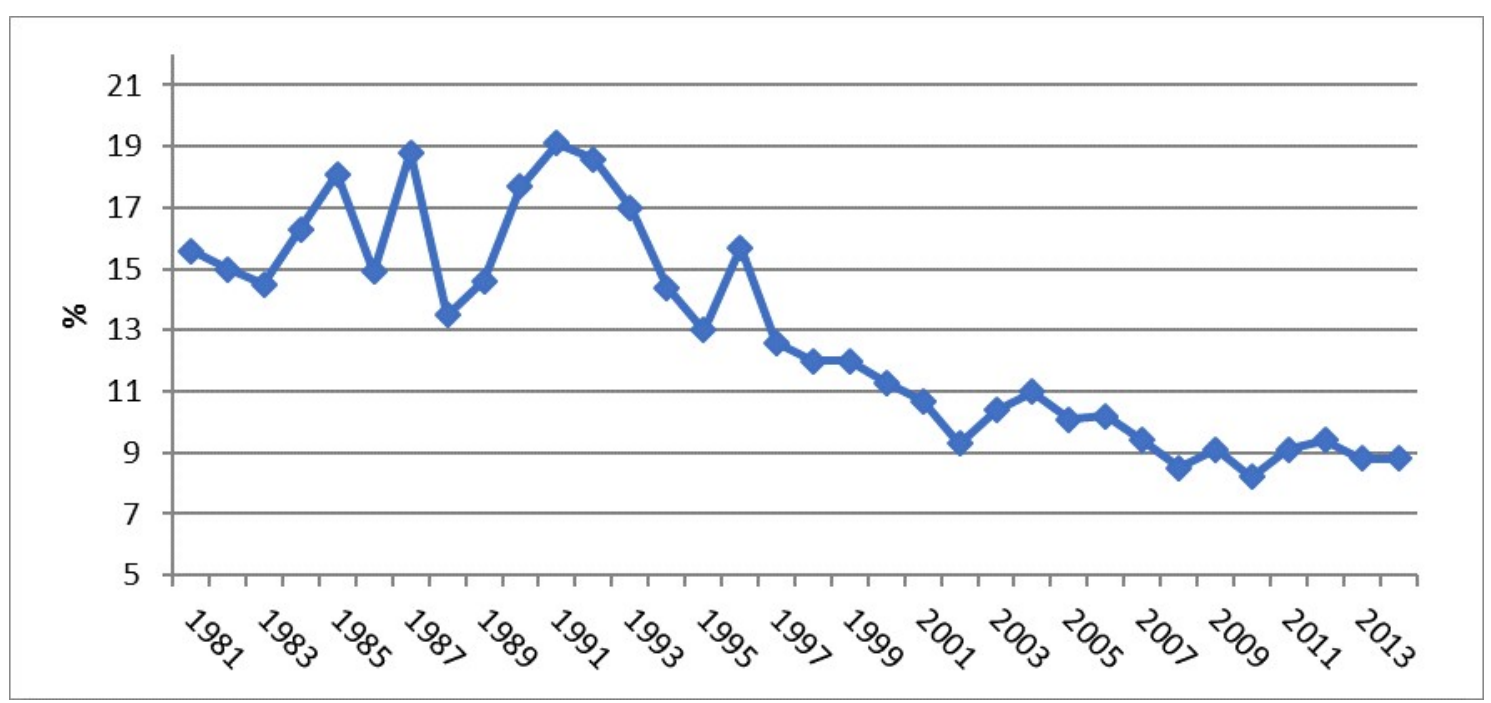

Source: Authors' elaboration using data from World Bank, World Trade Indicators (WTI), 2016

In spite of the aforementioned reduction, agriculture remains one of the driving forces of economic and social development in Tunisia. The Tunisian agriculture is the only source of income for nearly half of the rural labor force (45\%) (African Development Bank, 2012). Agriculture employs between 16 and $20 \%$ of the total active population (INS, 2014). 
Chapter 6. Food security, competitiveness and trade: The case of Tunisian agriculture

Tunisia has undergone a revolution and is experiencing a long democratic transition, which leads to much economic turbulence, such as the trade deficit. Five years after the Tunisian revolution, the trade deficit has rapidly increased from -8603.5 to -12047.4 MTND in the period 2011-2015 with an average annual growth of $-8.78 \%$ (Table 15 ).

Table 15. Tunisian Trade balance in MTDN (2011-2015)

\begin{tabular}{|c|c|c|c|}
\hline Year & Annual exports & Annual Imports & Trade balance \\
\hline 2011 & 25092.0 & 33695.4 & -8603.5 \\
\hline 2012 & 26547.6 & 38178.0 & -11630.3 \\
\hline 2013 & 27701.1 & 39509.4 & -11808.2 \\
\hline 2014 & 28406.8 & 42042.5 & -13635.7 \\
\hline 2015 & 27607.1 & 39654.5 & -12047.4 \\
\hline \multicolumn{3}{|c}{ Source: Author's elaboration using data from INS, 2016} \\
\hline
\end{tabular}

The agri-food balance follows the same trend of trade deficit. It can be explained by the strong increase in domestic demand. In the period 2005-2013, the gap between imports and exports grew. The persistence of a deficit in agri-food trade endangers food security in Tunisia as it raises the dependence on international markets (Figure 14).

Figure 14. Evolution of Tunisian's Agri-food imports and exports (1993-2015)

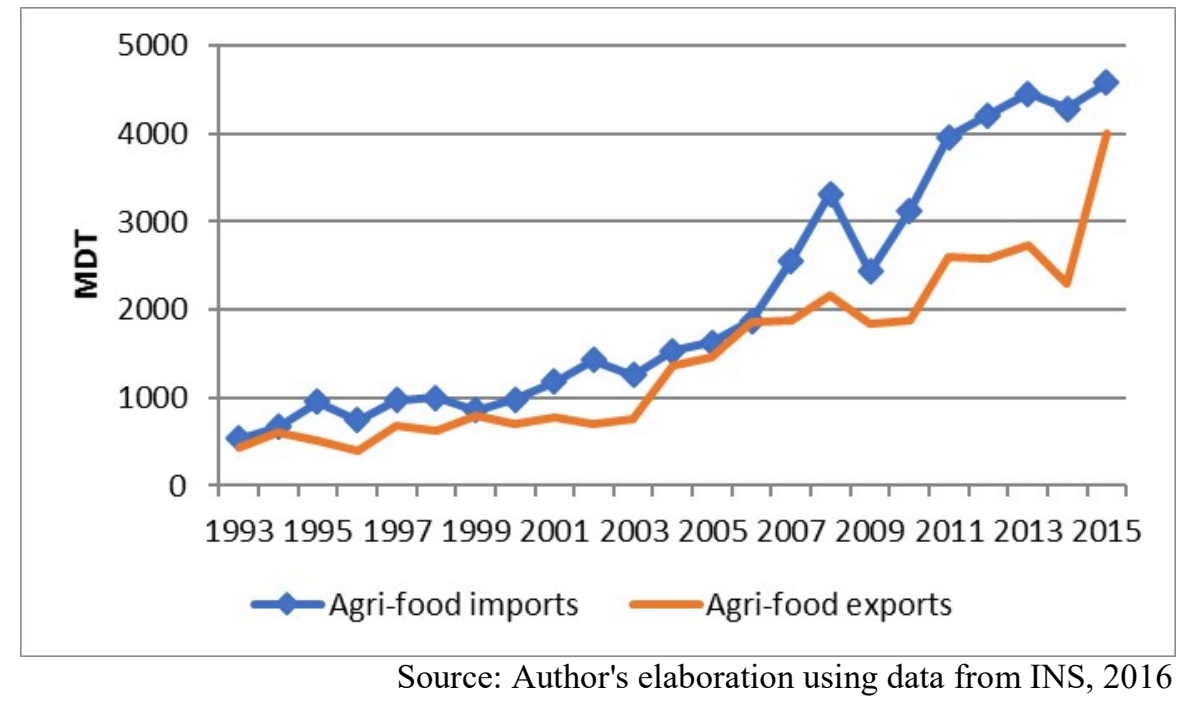

Tunisian agri-food exports are highly dependent on few commodities, being olive oil and dates considered as flagship products. Indeed, Tunisia is an international leader in exporting olive oil and it has the highest market share in exporting date to the international market. In 2014, the agri-food export is composed mainly of olive oil (484,35MTND); fruits (509.82MTND, of which 388.43MTND of dates) and fish and crustaceans (231.45MTND). 
Chapter 6. Food security, competitiveness and trade: The case of Tunisian agriculture

Olive oil, dates and fish exports represent together about $50 \%$ of the value of Tunisian agrifood exports (Table 16).

Table 16. Structure of agri-food exports (2009-2014)

(in \% of Tunisian agri-food exports in MTDN)

\begin{tabular}{|c|c|c|c|c|}
\hline Year & Olive oils & Fish and crustaceans & Dates & Other \\
\hline 2009 & 28.84 & 9.84 & 12.85 & 48.47 \\
\hline 2010 & 23.65 & 9.82 & 15.22 & 51.31 \\
\hline 2011 & 15.57 & 9.78 & 11.48 & 63.17 \\
\hline 2012 & 23.02 & 8.26 & 13.36 & 55.36 \\
\hline 2013 & 29.93 & 8.16 & 13.86 & 48.05 \\
\hline 2014 & 21.08 & 10.08 & 16.91 & 51.93 \\
\hline
\end{tabular}

Source: INS, 2016

These products are an important source of foreign currencies, which can help considerably to compensate the country's cost of seed oils imports' and other primary products such as cereals (Sai and Msallem, 2005). Indeed, Tunisian imports of cereals and seed oils in 2013 represented about 50\% of its agri-food imports (Table 17).

Table 17. Structure of agri-food imports (2009-2013)

(in \% of Tunisian agri-food imports in MTDN)

\begin{tabular}{|c|c|c|c|c|}
\hline Year & Cereals & Seed oils & Sugar & Others \\
\hline 2009 & 25.11 & 12.07 & 7.57 & 55.25 \\
\hline 2010 & 34.72 & 11.76 & 9.17 & 44.35 \\
\hline 2011 & 31.77 & 16.92 & 11.98 & 39.33 \\
\hline 2012 & 31.66 & 13.47 & 8.75 & 46.12 \\
\hline 2013 & 37.19 & 10.31 & 6.8 & 45.70 \\
\hline
\end{tabular}

To date, the EU is by far Tunisia's main trade partner in agri-food products, although reciprocity is not the case given the size of the country in comparison with the EU. In 2014, Tunisia imported $50.7 \%$ of its agri-food needs from EU countries and exported over $40 \%$ of its exports to the EU. These exports experienced a growth rate of over $62 \%$ from 2001 to 2014, whereas imports grew at an estimated average annual rate of 15\% (See Figure 15). Trade preferences given to MPCs by the EU do not impact on the export dynamics but reinforce the traditional trade pattern of these countries with the EU. In fact, there has been a limited impact of the Barcelona Process on agricultural trade (Abis, 2011; Garcia AlvarezCoque and Martinez, 2016). 
Chapter 6. Food security, competitiveness and trade: The case of Tunisian agriculture

Figure 15. Evolution of Tunisia's agri-food imports and exports from the European Union (2001-2014)

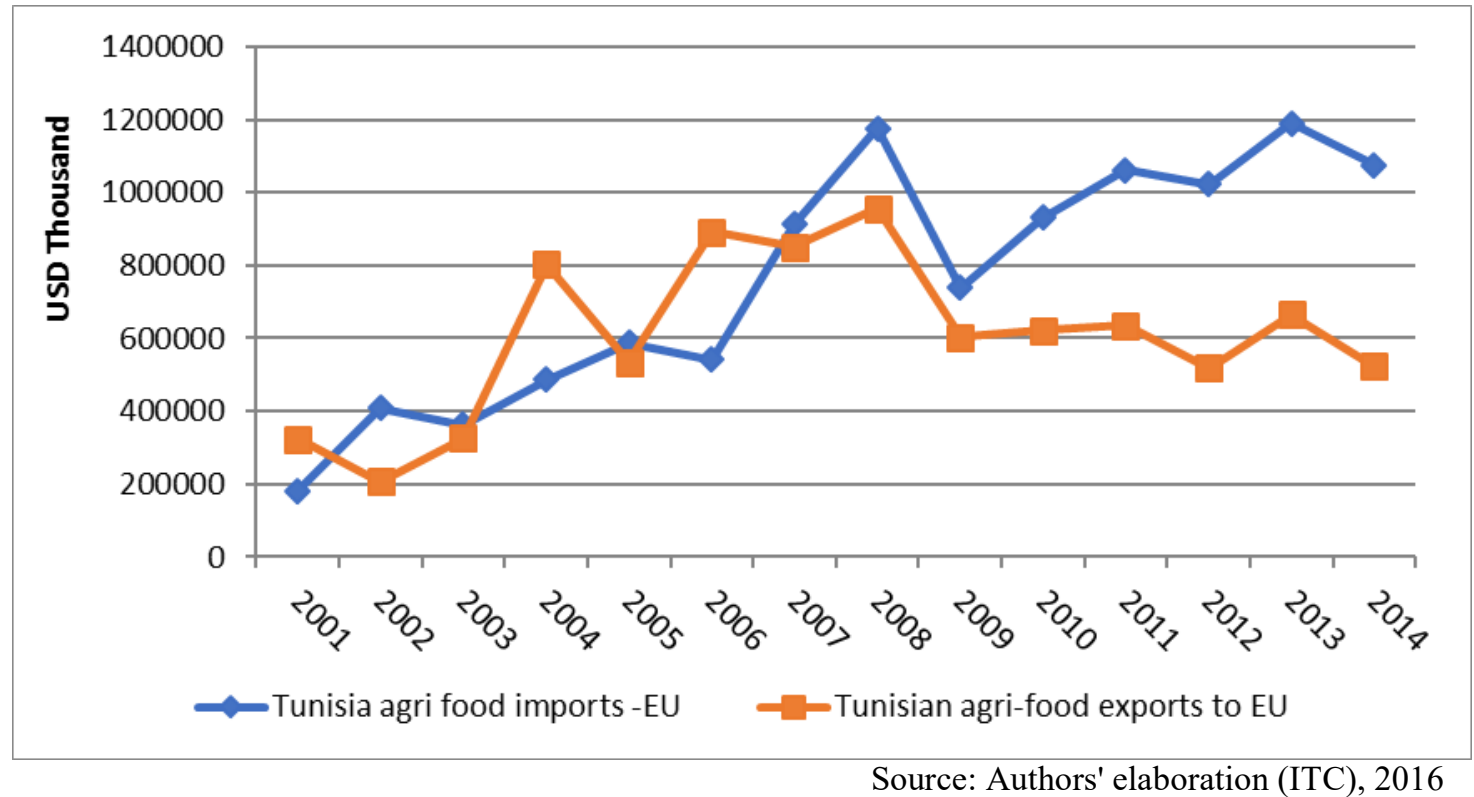

\section{Expected benefits and shortcomings of the DCFTA}

The new DCFTA will facilitate trade between the EU and Tunisia. Indeed, only the agricultural sector will benefit from tariff reduction, as tariffs on industrial products are already eliminated. Agricultural tariffs on Tunisian imports from Europe will be reduced by $80 \%$ while tariffs in the European market on imports from Tunisia will be mitigated by $95 \%$ (Ecorys, 2013).

Simulations indicate that the expected effect is that Tunisian exports will increase and enhance trade balance. This will have a positive effect on wages in general and on agricultural revenue in particular, leading to considerable increase in the purchasing power of producers (Ecorys, 2013). The national income of both the EU and Tunisia is likely to increase in the long term as a result of this agreement. Given the size of the economies, Tunisian benefit in GDP is expected to be bigger than the European one. As a result, such an agreement would be in favor of Tunisia and consolidate its privileged partnership with Europe (Ecorys, 2013).

In spite of the importance of expected benefits of the DCFTA to Tunisian economy, it is worth noting several negative effects that it can have. On the one hand, Tunisian producers might face high competition in exporting agri-food staples to Europe given the similarity of products produced in the Mediterranean area. Thus, producers may lose their comparative advantage due to competition from the other EU providers. 
Chapter 6. Food security, competitiveness and trade: The case of Tunisian agriculture

As a dynamic effect, the new trade environment may lead small Tunisian producers to adapt not only to a new type of competition with European products and neighbors such as Morocco and Turkey, but also to the European food safety standards and rules (Compés López et al., 2013).In the domestic arena, another short coming of the DCFTA is the additional drop in the levels of protection (Ecorys, 2013) and the subsequent increase in competition caused by the availability of foreign agri-food products in the Tunisian market. In turn, this may result in the impoverishment of small domestic producers. Currently, most agricultural programs in Tunisia include subsidies to increase production level and protect the family farm model (see next section).

It is worth mentioning that the integration of agriculture in DCFTA negotiations is complicated even on the European side. One reason is that agriculture, especially the fruit and vegetables sub-sector, is considered to be one of the main sources of conflict in the relation between the EU and the MPC (Jordán et al., 2011; García Alvarez Coque et al., 2008) due to the increased competition that EU producers face from the MPC.

\section{Support to agriculture in Tunisia}

The Tunisian agricultural policy has focused traditionally on maximizing production by intensifying the use of inputs such as chemical supplies and fertilizers, seeds and improved varieties, or on improving irrigation and water infrastructure. Thus, agricultural activities were planned according to national guidelines and objectives of food self-sufficiency by supporting agriculture production prices and subsidizing most agricultural inputs (AFDB, 2012). Before the Tunisian revolution, the deepening of trade liberalization was always accompanied by severe supervision by inter-professional groups to limit competition and improve market efficiency (Elloumi, 2006). However, pricing of agri-food products is no longer under the control of the inter professional organizations but is determined by market forces. These organizations roles have been limited to the coordination between the different stakeholders, such as producers and exporters.

The Nominal Protection Coefficient for Producers (NPCp) is the ratio between the average price received by domestic producers for their products at the farm gate (including payment per ton of current output), and the border price that they would receive if the product were freely traded according to international market conditions. An NPCp greater than 1 means that the producers of the commodity are protected by border measures influencing prices (OECD, 2011). 
Chapter 6. Food security, competitiveness and trade: The case of Tunisian agriculture

FAOSTAT and INS data have been used to compute NPCp. Table 18 presents the NPCp of beef, poultry meat and bread wheat. We have chosen these products given their importance in the Tunisian market.

In general terms, the changes in NPCp over the period considered show a diminution of protection for these three basic food products. This fact can be explained by a gradual trend toward more neutral support to producers in the framework of more liberalized markets, which leads to a reduction of tariff protection.

The evolution of NPCp for beef over a period of 15 years (1998-2012) shows that domestic producers were not protected by government measures affecting prices. In addition, the average nominal protection coefficient of poultry meat decreased to less than 1 . It dropped from 1.15 during the second period (2003-2007) to 0.87 during the third period (2008-2012). Regarding soft wheat, the protection factor is always greater than 1 with the exception of the last year in that period, reflecting the importance of this product in domestic agricultural policies. However, a downward trend since 1998 is noticeable. More generally, cereals continue to receive substantial attention within the support policies and take advantage of financial support at the expense of other sectors such as beef and poultry meat.

In this sense, an additional liberalization of agri-food trade raises a question about its impact on Tunisian local markets and on food security. The debate is whether additional trade liberalization can enhance food security via the increment of exports. In this context, it is fundamental to analyze the evolution of the economic competitiveness of the Tunisian agricultural sector since Tunisia has become a member of the free trade EuropeanMediterranean area. Such an analysis may help policy makers to study the impact of the DCFTA based on previous experiences. 
Chapter 6. Food security, competitiveness and trade: The case of Tunisian agriculture

Table 18. Nominal Protection Coefficient for producers- Tunisia

\begin{tabular}{|c|c|c|c|c|c|c|c|c|c|c|c|c|c|c|c|}
\hline \multirow[t]{2}{*}{ Year } & \multicolumn{5}{|c|}{1} & \multicolumn{5}{|c|}{2} & \multicolumn{5}{|c|}{3} \\
\hline & 1998 & 1999 & 2000 & 2001 & 2002 & 2003 & 2004 & 2005 & 2006 & 2007 & 2008 & 2009 & 2010 & 2011 & 2012 \\
\hline Bovine meat & 0.73 & 0.63 & 0.55 & 0.56 & 0.59 & 0.48 & 0.56 & 0.49 & 0.54 & 0.53 & 0.50 & 0.53 & 0.53 & 0.53 & 0.49 \\
\hline Average & \multicolumn{5}{|c|}{0.61} & \multicolumn{5}{|c|}{0.52} & \multicolumn{5}{|c|}{0.52} \\
\hline Poultry meat & 1.27 & 1.32 & 1.23 & 1.03 & 1.24 & 1.42 & 1.18 & 1.02 & 1.07 & 1.06 & 0.72 & 1.05 & 0.85 & 0.82 & 0.90 \\
\hline Average & \multicolumn{5}{|c|}{1.24} & \multicolumn{5}{|c|}{1.15} & \multicolumn{5}{|c|}{0.87} \\
\hline Soft wheat & 2.25 & 2.47 & 2.17 & 1.91 & 1.59 & 1.66 & 1.63 & 1.73 & 1.44 & 1.04 & 1.20 & 1.71 & 1.31 & 1.06 & 0.93 \\
\hline Average & \multicolumn{5}{|c|}{2.08} & \multicolumn{5}{|c|}{1.50} & \multicolumn{5}{|c|}{1.24} \\
\hline
\end{tabular}




\subsection{Methodology: measuring the competitiveness of Tunisian agri-food products}

Several definitions have been used in previous literature to define competitiveness. It changes depending on the purpose of the analysis and the studied product. Indeed, various approaches have been used to analyze the competitiveness of international agri-food trade. In this chapter, the Revealed Comparative Advantage (RCA) index is used to assess the competitiveness of Tunisian products with respect to its partners (the EU and the Arab Maghreb Union UMA). Data on Tunisian exports by HS chapter are obtained from the National Institute of statistics (INS) and include exports by commodity from chapters HS01 to HS23 and partner country from 2007 to 2012. Values are presented in Tunisian dinars.

\section{Balassa Revealed Comparative Advantage (RCA) index}

This index was used for the first time by Liesner (1958) and improved by Balassa in 1965. It came to be known as the "Balassa Index" and it measures normalized export shares of a country, compared to exports of the same industry in a group of reference countries.

Balassa (1965) defined the RCA index as the ratio between exports of certain products (HS2 chapter) of a country (in this study Tunisia) and total exports of this country to the rest of the world (or the geographical reference area; in this study we consider the EU and UMA as a geographical reference area), and world exports (or the geographical reference area) of the same product to the total world exports (or the geographical reference area) (Vollrath, 1991; Bojnec, 2001).

RCA can take positive or negative values. Positive values of RCA are interpreted as meaning that the country has comparative advantage. The Balassa RCA is defined as:

$$
R C A_{i}=\frac{X_{i}-M_{i}}{X_{i}+M_{i}}-\frac{\sum\left(X_{i}-M_{i}\right)}{\sum\left(X_{i}+M_{i}\right)}
$$

where

$X_{i}$ represents exports from Tunisia of HS2 sector (i);

$M_{i}$ represents imports of HS2 sector (i)

While the index is not free of shortcomings (see Cai and Leung, 2007), it is still widely used for a first approximation to the measure of competitiveness. As an instance, at the end of the previous century, Chebbi and Gil (1999) presented a general diagnostic of Tunisian 
Chapter 6. Food security, competitiveness and trade: The case of Tunisian agriculture

agri-food sector competitiveness with the EU during the period 1975-1995 using the RCA index. An overview by group of products revealed that products of animal origin present a slightly higher competitive advantage compared to other sub-sectors thanks to the high competitiveness of HS2 03 (fish and crustaceans) and the strong Tunisian marketing strategy to promote fishery exports. In addition, the authors found that the competitiveness of the vegetable sub-sector deteriorated over the period of study. They pointed out to the irregularity and low production level, of which a major proportion is absorbed by domestic demand (Arfa, 1995). On the other hand, they showed that the competitiveness of dates and olive oil was improved due to their competitive prices and improved quality compared to those of their direct competitors.

\subsection{Results and discussion}

Empirical results of our calculations are reported in table 19. They reveal the current competitive position of the Tunisian productive sectors. Beginning with the three traditional subsectors of relevance in Tunisian exports and the EU market, our findings show that Tunisian exports of fish and crustaceans are competitive, in spite of the fact that over the last decade there has been a loss of competitiveness given the significant decline in the RCA from $84 \%$ in 1995 (Chebbi and Gil, 1999) to 26\% 2012. Many efforts have been made by the government in previous years to promote fish and crustacean exports and to implement more effective management of fisheries. In terms of services, the government has decided to launch an upgrade program with the French Development Agency to prepare Tunisian firms for the new phase of liberalization. These efforts could be extended to other sectors and used as lessons of competitiveness-enhancing policies. Modernization of the production fleet which is very old and traditional and better organization of the subsector will enhance the competiveness of local producers and can reverse the negative trend detected.

Regarding animal or vegetable fats, oil and waxes products, the RCA has decreased from 48\% in 1995 (Chebbi et Gil, 1999) to 21\% in 2012. However, it is still positive and Tunisia remains competitive. A major part of this competitiveness stems from olive oil exports. Nonetheless, there is an ample margin to improve competitiveness of this sector since a major part of olive oils is exported to the EU under Inward Processing Relief Traffic (IPRT) conditions. Indeed, Tunisian olive oils are re-exported under European brands after processing or just bottling (Anania and Pupo d'Andrea, 2011). 
Chapter 6. Food security, competitiveness and trade: The case of Tunisian agriculture

Fruits also show a positive RCA over the period of study, as vegetables do during most of the period. Overall, our findings prove that these sectors could take advantage of the free trade with the EU as chapters 07, 08, 09 and 14 display high competitiveness. Particularly, dates are included in chapter 08. Despite the strong performance of the dates sector, several structural weakness and handicaps have been identified in this sector. Literature mentions the several possible causes such as the insufficient production material and techniques, the lack of research and marketing services, weak farming organizations, the irregularity of the trading system and the inconsistent quality of the packaged products, as well as a high rate of product infestation (APIA, 2008; Jemni et al., 2014).

Turning now to the relevant products that show negative competitiveness, the RCA of live animals has substantially decreased to reach an indicator of $-140 \%$ compared to Chebbi and Gil's (1999) results. They computed an RCA of $-60 \%$ in 1995 before Tunisia was engaged in the Barcelona process. Furthermore, the meat and edible meat offal subsectors display a similar trend suggesting that these Tunisian sectors do not have any comparative advantage to export this type of products to Europe. The decreasing protection shown earlier may be the cause behind the low competitiveness of local production. On the other hand, at the policy level the RCA of meat subsector could be improved as long as farmers' performance can be enhanced through information campaigns, training actions and extension services.

Despite the relevant importance of cereal sector within the Tunisian agricultural policies, the RCA indicator continues to be negative indicating that local producers are less competitive than their European counterparts. In fact, Tunisia does not have a comparative advantage to produce cereals and indeed imports from the EU are still very important. Many factors are behind the low competitiveness of this sector. In Tunisia, farmers are far from the international cereal production standards (Bachta, 2011). Furthermore, increasing input costs borne by Tunisian farmers reduce their competitiveness compared to their EU counterparts. On the other hand, the potential of production in Tunisia is not yet achieved due to the spread of small farm size which represents about $75 \%$ of the total. Thus, local production cannot take advantage of economies of scale.

With respect to another geographic trade area (UMA), it is worth noting that the countries of UMA have a similar economic structure with the dominance of the agricultural sector. Indeed, they offer similar agri-food products. In general, it appears that Tunisian products are more competitive than their UMA counterparts. However, it is important to note 
Chapter 6. Food security, competitiveness and trade: The case of Tunisian agriculture

that the agri-food trade flows with UMA countries are limited and restricted to a small number of agri-food products.

\subsection{Conclusion and policy implications}

The EU and Tunisia share common interests for expanding the cooperation in terms of agrifood products. So, Tunisian authorities will deepen the aggressive trade liberalization agenda by signing the DCFTA. However, several issues that require the employment of pro-active strategies will be crucial to avoid negative impacts of the DCFTA in some sub-sectors. Indeed, the liberalization process needs an institutional and legislative adaptation to the EU's standards and rules which could affect Tunisian agri-food exports and lead to various social costs. Hence, it can put some basic domestic agri-food products at stake due to increased competition.

Food security and self-sufficiency constitute the major concerns of Tunisian government, especially with trade liberalization. One strategy to achieve food security consists on relying on exports of competitive products to compensate for the bill of basic food products. In this context, the analysis of the competitiveness of agri-food trade with the EU and neighboring countries makes this study especially interesting.

Our empirical findings reveal that the biggest relative increase in Tunisian exports is expected to come mainly from the sectors of fruits, fish and olive oil given the high competitiveness shown at the EU market. Moreover, these products are likely to expand in terms of value added, which would lead to positive spillover effects. Then, Tunisian efforts could focus on obtaining more significant trade benefits in these sectors. Marquez and Martinez-Gomez (2016) show that this strategy has been fruitful to enhance Moroccan exports of fruits and vegetables.

Another point to stress, consistent with Chebbi and Gil's (1999) findings, is that the competitiveness of the Tunisian agricultural sector differs significantly according to geographical areas of trade. The three most competitive sectors in the EU market are not so competitive in the UMA market. Otherwise, the rest of the products increase their competitiveness at the UMA. Hence, one Tunisian policy option would be to deepen the UMA trade so that exports of competitive products increase to Maghreb partners and then, through a learning-by-doing process, they can raise their overall competitiveness and become ready for the global markets. 
Chapter 6. Food security, competitiveness and trade: The case of Tunisian agriculture

Indeed, in the short-term some agri-food subsectors, mainly animal products, milk and dairy products and cereals, remain unprepared to support the costs of the DCFTA due to their low competitiveness. Then, Tunisian authorities could propose a progressive trade liberalization strategy with the EU.

In the meanwhile, Tunisia could encourage foreign direct investment in these sectors to improve their competitiveness. Another measure to foster producers' competitiveness is to promote the adoption of adequate varieties with quality control and certification facilities. Beyond the "pure" export strategies, Petit (2015) and Petit et al. (2015) emphasize the role of civil society organizations and local institutions to enhance agricultural and rural development for a sustainable food security in Mediterranean countries, and point out to the ENPARD funding and European experiences to achieve this goal.

\section{Acknowledgments}

J.M. Garcia Alvarez Coque and V. Martinez-Gomez wish to thank the Spanish Ministry of Economy and Competitiveness for supporting the research project AGL2015-65897-C3-3-R; V. Martinez-Gomez is grateful to the support given by Generalitat Valenciana, research project GV/2015/073. 
eness and trade: The case of Tunisian agriculture

19. RCA index of the Tunisian Agri-food products with the EU and UMA (\%)

\begin{tabular}{|c|c|c|c|c|c|c|c|c|c|c|c|c|}
\hline & \multicolumn{6}{|c|}{ Tunisia-UE } & \multicolumn{6}{|c|}{ Tunisia - UMA } \\
\hline & 2007 & 2008 & 2009 & 2010 & 2011 & 2012 & 2007 & 2008 & 2009 & 2010 & 2011 & 2012 \\
\hline & -144 & -134 & -136 & -138 & -132 & -140 & 189 & 175 & 182 & 193 & 197 & $\underline{189}$ \\
\hline & -127 & -121 & -149 & -112 & -123 & -139 & -32 & 4 & $\underline{7}$ & $\underline{14}$ & -133 & -174 \\
\hline & $\underline{37}$ & $\underline{35}$ & $\underline{1}$ & $\underline{22}$ & $\underline{42}$ & $\underline{26}$ & -147 & -142 & -120 & -80 & -100 & -94 \\
\hline & -132 & -123 & $\begin{array}{l}-139 \\
\end{array}$ & -121 & -117 & -128 & $\underline{102}$ & $\underline{126}$ & $\underline{106}$ & $\underline{114}$ & $\underline{87}$ & $\underline{114}$ \\
\hline & $\underline{62}$ & $\underline{72}$ & $\underline{55}$ & $\underline{73}$ & $\underline{76}$ & $\underline{65}$ & -155 & -156 & $\begin{array}{l}-108 \\
\end{array}$ & -44 & -52 & -17 \\
\hline & -29 & -18 & -40 & -41 & -29 & -48 & $\underline{64}$ & $\underline{74}$ & $\underline{70}$ & $\underline{87}$ & $\underline{78}$ & $\underline{38}$ \\
\hline & -57 & $\underline{2}$ & -49 & $\underline{26}$ & $\underline{17}$ & $\underline{1}$ & -52 & -45 & -31 & -78 & $\underline{11}$ & $\underline{8}$ \\
\hline melons & $\underline{65}$ & $\underline{76}$ & $\underline{59}$ & $\underline{77}$ & $\underline{80}$ & $\underline{71}$ & $\underline{17}$ & $\underline{13}$ & $\underline{16}$ & $\underline{14}$ & $\underline{17}$ & $\underline{11}$ \\
\hline & $\underline{62}$ & $\underline{70}$ & $\underline{50}$ & $\underline{54}$ & $\underline{45}$ & $\underline{36}$ & $\underline{90}$ & $\underline{94}$ & $\underline{90}$ & $\underline{114}$ & $\underline{134}$ & $\underline{132}$ \\
\hline & -132 & -123 & -139 & -121 & -117 & -128 & $\underline{90}$ & $\underline{169}$ & $\underline{0}$ & $\underline{0}$ & $\underline{191}$ & $\underline{198}$ \\
\hline & -132 & -123 & -127 & -90 & -113 & -127 & $\underline{46}$ & $\underline{2}$ & $\underline{18}$ & $\underline{63}$ & $\underline{62}$ & $\underline{30}$ \\
\hline traw & -66 & -80 & -96 & -78 & -59 & -81 & -34 & $\underline{4}$ & $\underline{25}$ & $\underline{62}$ & $\underline{13}$ & $\underline{19}$ \\
\hline & -132 & -123 & -130 & -116 & -117 & -124 & $\underline{75}$ & $\underline{35}$ & $\underline{108}$ & $\underline{140}$ & $\underline{33}$ & $\underline{89}$ \\
\hline & $\underline{62}$ & $\underline{69}$ & $\underline{54}$ & $\underline{74}$ & $\underline{62}$ & $\underline{71}$ & $\underline{36}$ & $\underline{34}$ & $\underline{24}$ & $\underline{41}$ & $\underline{8}$ & $\underline{37}$ \\
\hline es & $\underline{45}$ & $\underline{54}$ & $\underline{33}$ & $\underline{54}$ & $\underline{27}$ & $\underline{21}$ & $\underline{48}$ & $\underline{70}$ & $\underline{59}$ & $\underline{71}$ & $\underline{82}$ & $\underline{71}$ \\
\hline staceans & $\underline{5}$ & $\underline{49}$ & $\underline{44}$ & $\underline{58}$ & $\underline{62}$ & $\underline{53}$ & $\underline{19}$ & $\underline{19}$ & $\underline{19}$ & $\underline{18}$ & $\underline{28}$ & $\underline{37}$ \\
\hline & -133 & -114 & -142 & -135 & -127 & -135 & $\underline{61}$ & $\underline{81}$ & $\underline{105}$ & $\underline{54}$ & $\underline{64}$ & $\underline{113}$ \\
\hline & -124 & -101 & -102 & -129 & -129 & -138 & $\underline{82}$ & $\underline{82}$ & $\underline{87}$ & $\underline{96}$ & $\underline{96}$ & $\underline{92}$ \\
\hline & -87 & -71 & -91 & -81 & -79 & -88 & $\underline{40}$ & $\underline{29}$ & $\underline{33}$ & $\underline{29}$ & $\underline{27}$ & $\underline{31}$ \\
\hline & -108 & -46 & -63 & -54 & -65 & -84 & $\underline{69}$ & $\underline{38}$ & $\underline{42}$ & $\underline{54}$ & $\underline{37}$ & $\underline{48}$ \\
\hline & $\underline{2}$ & -3 & $\underline{8}$ & $\underline{7}$ & -9 & -33 & -26 & -29 & -38 & -22 & -9 & -40 \\
\hline & -12 & $\underline{12}$ & -8 & -13 & -1 & -44 & -84 & -47 & -38 & -77 & -33 & -15 \\
\hline
\end{tabular}


Chapter 6. Food security, competitiveness and trade: The case of Tunisian agriculture

\section{References}

Abis, S. (2011). Libéralisation du commerce agricole et coopération pour la sécurité alimentaire. Euromed Survey:euro-mediterranean policies in the light of the arab spring, (third ed.). IEMed. Barcelona.

Abis, S. (2012). Wheat in the Mediterranean region: Societies, trade and strategies. Barcelona: European Institute Of The Mediterranean (IEMed).

African Development Bank. (2012). Distortions to agricultural policy incentives in Tunisia: A preliminary analysis. http://www.afdb.org/fileadmin/uploads/afdb/Documents/Publications/Brochure\%20no te $\% 20$ politique $\% 20$ agriculture $\% 20$ Anglais.pdf

Agence de Promotion des Investissements Agricoles de la Tunisie. (2008). Étude de positionnement stratégique de la Deglet Nour Tunisienne et de la promotion de ses exportations à long et moyen terme.

Akesbi, N. (2011). L'agriculture Marocaine, est-elle apte au libre-echange?. Revue Marocaine De Sciences Politique Et Sociale, 2 (1): 47-85.

Anania, G., and D'Andrea, M. R. P. (2011). Olive oil in the Mediterranean area: Production, consumption and trade. The CIHEAM Watch Letter, 16.

Arfa, L. (1995). Evolution et avenir des échanges agro-alimentaires de la Tunisie avec l' Union Européenne. Options Méditerranéennes, 14 (Serie B), 43-57. http://ressources.ciheam.org/om/pdf/b14/CI960041.pdf.

Bachta, M. S. (2011). La céréaliculture en Tunisie: une politique de régulation a repenser. Les $\begin{array}{llll}\text { Notes D'Analyse } & \text { Du }\end{array}$ http://ciheam.org/images/CIHEAM/PDFs/Observatoire/NAN/nan64.pdf.

Balassa, B. (1965). Trade liberalisation And "Revealed" Comparative Advantage". Manchester School, 33 (2), 99-123. doi:10.1111/j.1467-9957.1965.tb00050.x.

Bojnec, Š. (2001). Trade and revealed comparative advantage measures: Regional and central and east European agricultural trade. Eastern European Economics, 39 (2), 72-98 http://www.jstor.org/stable/4380256.

Cai, J. \& Leung. P. S. (2007). Toward a more general measure of revealed comparative advantage variation. Applied Economic Letters, 15(9), 723-726.

Chebbi, H. E. \& Gil, J. M. (1999). Le commerce agro-alimentaire Tunisien avec l'Union Européenne et le pays du Maghreb Arabe : Une analyse structurelle de la 
Chapter 6. Food security, competitiveness and trade: The case of Tunisian agriculture

Compétitivité. Mediterranean Journal of Economics, Agriculture and Environment, 3(99), 18-23. http://www.iamb.it/share/img new medit articoli/678 18 chebbi.pdf.

Compés López, R., Garcia-Alvarez-Coque, J. M. \& García Azcárate, T. (2013). EUMediterranean relations in the field of agriculture. The example of Morocco and Turkey. Notre Europe. Jacques Delors Institute. http://www.institutdelors.eu/media/mediterraneanagriculture-lopezgarciagarcia-ne-jdiapr13.pdf?pdf $=$ ok.

Ecorys,. (2013). Trade sustainability impact assessment in support of negotiations of a DCFTA between the EU and Tunisia. Rotterdam. http://trade.ec.europa.eu/doclib/docs/2013/november/tradoc 151923.pdf.

Elloumi, M. (2006). L'agriculture Tunisienne dans un contexte de libéralisation. Région Et Développement, 23, 129-152. http://region-developpement.univ$\underline{\text { th.fr/fr/pdf/R23/R23 Elloumi.pdf. }}$

Food and Agriculture Organization of the United Nations, (2016). http://www.fao.org/home/en/.

Garcia-Alvarez-Coque, J. M. \& Martinez-Gomez, V. (2016). Agricultura y alimentación, prioritarias en la cooperación Euromediterránea. Afkar/Ideas , 49(primavera 2016), 5254

Jordán, J. M. , Garcia-Alvarez-Coque, J. M. \& Martinez-Gomez, V. (2011). La agricultura y el espacio Euromediterraneo : Recursos, competitividad y políticas. Informacion Comercial Espanola, 861, 11-28

Garcia-Alvarez-Coque, J. M., Jordán Galduf, J. M., \& Martinez Gomez. V. (2008). El modelo europeo de agricultura y los acuerdos internacionales. Papeles De Economía Española, 117, 227-242.

Jemni, M., Otón, M., Ramirez, J.G., Artés-Hernández, F., Chaira, N., Ferchichi, A., et al. (2014). Conventional and emergent sanitizers decreased ectomyelois ceratoniae infestation and maintained quality of date palm after shelf-life. Postharvest Biology And Technology, 87: 33-41. doi:10.1016/j.postharvbio.2013.08.002.

Liesner, H. H. (1958). The European Common Market and British Industry. The Economic Journal, 68 (270), 302. doi:10.2307/2227597.

Márquez Ramos, L., \& Martinez-Gomez, V. (2016). On the effect of EU trade preferences: Evidence for monthly exports of fruits and vegetables from Morocco. Mediterranean Journal of Economics, Agriculture and Environment, 15(2), 2-13. 
Chapter 6. Food security, competitiveness and trade: The case of Tunisian agriculture

National Institute of Statistics (INS), 2016. http://www.ins.nat.tn/

Organisation for Economic Co-operation and Development,. (2011).OECD'S Producer support estimate and related indicators of agricultural support concepts, calculations, interpretation and use (The PSE Manual). http://www.oecd.org/tad/agriculturalpolicies/46193164.pdf.

Petit, M. (2015a). Sustainable Mediterranean agriculture for food security? Challenges for the Euro-Mediterranean Relationship. In M. C. Paciello (Ed.), Building sustainable agriculture for food security in the EuroMediterranean Area: Challenges and policy options. Rome: Edizioni Nuova Cultura, 253-280.

Petit, M. (2015b). Sustainable Mediterranean Agriculture for food security? Challenges for the Euro-Mediterranean Relationship. In M. C. Paciello (Ed.), Building sustainable agriculture for food security in the EuroMediterranean Area: Challenges and policy options. Rome: Edizioni Nuova Cultura, 253-280.

Petit, M., Gautier, F. E.-H., García Alvarez-Coque, J. M., Mili, S., Mattas, K., \& Montaigne, E. (2015) Conclusion. In Petit et al. (Eds.), Sustainable agricultural development. Challenges and approaches in Southern and Eastern Mediterranean Countries. Springer, 197-225.

Saï, M. E. B., \& Msallem, M. (2005). Le secteur oléicole en Tunisie: De la protection a la libéralisation. Les Défis De La Terre: L’Agriculture En Espagne Et En Tunisie Face Au Défi De La Libéralisation. Tunis: Cérès Editions and IRESA, 203-222.

Santeramo, F. G. (2014). On the composite indicators for food security: Decisions matter! Food Reviews International, 31(1), 63-73. doi: $10.1080 / 87559129.2014 .961076$.

Vollrath, T. L. (1991). A theoretical evaluation of alternative trade intensity measures of revealed comparative advantage. Weltwirtschaftliches Archive, 127(2), 265280. doi: $10.1007 / \mathrm{bf} 02707986$.

World Bank (WB). (2016). http://www.worldbank.org/ 
General discussion 


\section{General Discussion}

NTMs are playing an increasingly important role in determining international trade patterns, especially concerning agri-food products. They are widely affected by the use of these measures representing the highest number of NTM claims with respect to their sectoral export value (United Nations Conference on Trade and Development, UNCTAD, 2005). However, the application of NTMs in agri-food trade has been commonly explained by two main factors. On the one hand, consumer health and food safety become more and more relevant and are placed at the center of new political decisions. On the other hand, tariffs have been extensively reduced through various Free Trade Agreements. Therefore, the employment of NTMs has an important role in determining agri-food trade flows. Recently, there has been a significant increase interest in monitoring these measures and quantifying their economic impact.

This chapter will discuss the main results achieved in the four previous chapters based on the following points:

- Presenting the advantages of using RASFF database to analyze the use of NTMs.

- Assessing the determining factors of applying NTMs in agri-food trade based on "Reputation effects".

- Identifying the controversial points in using count models.

Earlier analyses of NTMs have mainly relied upon the UNCTAD TRAINS database because the latter provides data on policy measures according to the Harmonized System nomenclature which includes various details on concerned product. Nevertheless, the main drawback of using TRAINS is that the irregularity of national reporting induces a significant time lag for some necessary information. Furthermore, while some data for both tariffs and imports are available for almost all countries, over one-third of countries (58 out of 149) have no data on NTMs (Ferrantino, 2006). Moreover, if available, data on NTMs are generally older than those for tariffs and imports. Indeed, an analysis of NTMs effects using that information permits to concentrate only on limited policies, products or countries. On the other hand, deriving consistent and unbiased estimates of NTMs effects needs a complete and detailed knowledge of the concerned product (origin, date of export, type of hazard...) and should incorporate as much information as possible. For instance, the implied policies, the procedures by which they are implemented and whether they have changed over time and the 
exact products are of considerable importance to conduct a sound assessment of NTMs impacts (Deardorff and Stern, 1998).

RASFF database has been put in place to overcome the shortcomings of the TRAINS information and to offer a useful tool to exchange information about measures taken responding to serious hazard detected in relation to food or feed. Indeed, it provides a complete information about notified products with public access. This portal was created by the European Commission to keep the information transparent for consumers, business operators and trade partners. However, publishing complete information should be accompanied with a balance between transparency and protection of information that could cause economic losses and affect the reputation of exporting countries.

Recent studies tend rather to use RASFF database to analyze the impact of SPS measures on agri-food trade. Kleter et al. (2009) explored the RASFF notifications to identify emerging trends in recent food safety issues. Besides, Jaud et al. (2013) used the same data source to determine the geographical concentration of EU agri-food imports. Given the advantage of RASFF over TRAINS database, the former has been used to achieve the specific objectives of the present thesis.

It is worth noting that the RASFF dataset record all notifications between 1979 to 2017 with the specification of the identity of the importing EU Member State, exporting country, product, hazard, type of notification and measure. Indeed, notifications are presented in verbal form and products are not coded into the Harmonized System and its conversion to HS code is a not an easy task. To do so, a word-recognition algorithm has been implemented and each notified product was coded based on the HS classification. Nonetheless, this tool does not evidently provide a complete codification and the user assessment is crucial for ambiguous verbal forms. All notifications are used to gather count data taking into account other explicative variables as the per capita GDP and the import value.

Because of the complexity and the heterogeneity nature of NTMS, a variety of methodological techniques have been employed. While one group of studies rely on direct approaches using more specific dataset to estimate the impact of NTMs (Otsuki et al., 2001) the second group has been interested in understanding the effect of NTMs on trade flows through indirect measurement (Head and Ries, 2001; Baldwin et al., 2004). In line with the first group, we use a direct approach to estimate the impact of food standards on agri-food trade based on three original datasets. 
Count regression model is commonly used in many disciplines while its application to analyze NTMs trade effects is often of limited use. The methodology is mainly based on the Poisson and Binomial models. While the former is suited to deal with unbounded counts, the latter best fit bounded data. Negative Binomial model is more flexible than Poisson model in that it can be employed to properly quantify the parameters in case of overdispersion problem. The latter results in underestimating the variance of the estimated variables which conduct to a misleading conclusion. There are two major solutions to account for overdispersion in the model. The first one relies on scaling the variance of the Poisson distribution by adding a dispersion parameter and multiplying it to the variance. The second one allows introducing new probability distribution to handle the dispersion, such as the Negative Binomial or the Zero Inflated Negative Binomial Model. Further, it is necessary to choose a robust model that reflects and accounts for these issues. In this regard, the high number of zeros in the response variable suggests the use of zero inflated negative binomial regression to correctly and consistently determine the parameters to be estimated (Lambert 1992; Greene 1994). In particular, the Zero Inflated models can be found in several previous studies in other areas such as environmental sciences (Agarwal et al. 2002), medicine (Bohning et al. 1996) and manufacturing (Lambert, 1996). However, using these alternatives to the Poisson model seems to be an innovative approach to estimate the impact of NTMs on agri-food trade. These different estimation techniques have been used throughout this document for comparison purposes to check the confidence and the robustness of our empirical findings. That is whether they coincide or not with other results obtained from different methods and whether they are or not within the range of existing estimates in the literature.

The model selection indicators such as AIC, BIC and Vuong were employed to justify the choice of selected model which is the best performing with employed data in the present Thesis. The most challenging task was about the selection of the ZINB model against the NB version as model comparison criteria do not lead to unequivocal conclusions. Indeed, ZINB does not always fit the data better the NB does. In datasets with excess zeroes, the ZINB does not always fit the data better than the NB does. The Vuong test indicates that the NB model provides a better fit to the data than the ZINB model. As model comparison criteria do not lead to unequivocal conclusions, we will make reference to both models' results and we added a restricted model in order to select which model could minimize the loss in fit with the data. 
In the last decade, the evaluation of NTMs impact on agri-food trade has been broadly examined. To our best knowledge, the assessment of reputation effect has received scant attention by the literature on NTMs modeling and tends to be rather scarce. The work conducted by Jouanjean et al. $(2012,2015)$ constitutes an exception to published literature on reputation effect on agri-food trade. They focused on the effect of reputation on developing countries exports' and this has been applied to United States food imports. Our research work contributes to fill this gap. It attempts to respond to the following question: Do the notifications received in previous years influence the current notifications in the case of European imports?

Interestingly, consistently with previous researches, we found that intensive use of NTMs is accompanied by an increasing notifications rate during the period of our study (1998-2013). The logic behind the concept, reputation effects, is to study the influence exerted by the issue of a food product notification for a given year on the probability of the application of future food notifications. Therefore, we are interested in verifying whether the "history matters" influences the application of NTMs. This conceptual issue sheds light on four types of reputation effects relative to the European countries: product, sector, exporting country and region. Results reveal that there are significant reputation effects at product, sector and country level. Besides, the previous year import value and per capita GDP of exporting country are identified relevant in determining the implementation of European SPS standards. The concept of reputation can be explained as well as "import memory" or "export response".

Our empirical findings support previous evidence found by Jouanjean et al (2015) for the US and introduce a new aspect dealing with the effect of reputation over time. Indeed, our results show a relatively strong effect in the case of short run notifications (one lagged year) in comparison with medium and long run. Besides, findings suggest that notifications are more affected by the reputation built at the product than country. In the case of Mediterranean Partner Countries, notifications are affected similarly by product and country reputation effects. However, there is no sign of an anti or pro Mediterranean bias in the way food safety policy is implemented at the EU borders which implies the absence of protectionist behavior against the EU.

To deepen our understanding of NTMs impact, we pay attention to examine the behavior of the EU in controlling AF contamination in nuts with respect to food policy changes (harmonization and relaxing). Two notable changes in regulations with respect to AF 


\section{General discussion}

standards have occurred to control the safety of imported nuts. Our empirical results confirm that EU notifications for nuts is affected by alerts and product own reputation. Furthermore, we conclude that low performance of exporting countries in trading nuts (and groundnut products) to comply with new standards on food safety could be improved through more cooperation between EU and their partners. The latter would be more involved in in NTMssetting process through international organizations and bilateral discussions would be of considerable importance to get more harmonization between European standards and their agri-food suppliers. This may lead to improve the likelihood of acceptability of exported products. On the other hand, progressive trade liberalization agreements are strongly recommended since many developing countries are not yet competitive to benefit from the opportunity offered by the developed country in terms of market access. However, the lack of necessary financial and technical resources prevents the integration of agro-exporting firms in the global value chains to comply with EU requirements regarding the quality of imported products. 
General discussion

\section{References}

Agarwal, D. K., Gelfand, A. E., \& Citron-Pousty, S. (2002). Zero-inflated models with application to spatial count data. Environmental and Ecological statistics, 9(4), 341355.

Baldwin, R. E., Forslid, R., Martin, P., Ottaviano, G., \& Robert-Nicoud, F. (2004). The coreperiphery model: key features and effects. In Brakman et al. (Eds.), The Monopolistic Competition Revolution in Retrospect. Cambridge University Press, Cambridge, 213-235.

Bohning, D., Dietz, E., Schlattmann, P., Mendonca, L., \& Kirchner, U. (1999). The zero-inflated Poisson model and the decayed, missing and filled teeth index in dental epidemiology. Journal of the Royal Statistical Society: Series A (Statistics in Society), 162(2), 195-209.

Deardorff, A. V., \& Stern, R. M. (1998). Measurement of nontariff barriers. University of Michigan Press.

Ferrantino, M. (2006). Quantifying the trade and economic effects of non-tariff measures. OECD Trade Policy Working Papers, No. 28, OECD Publishing. doi: $10.1787 / 837654407568$

Greene, W. H. (1994). Accounting for excess zeros and sample selection in Poisson and negative binomial regression models. New York: New York university, Leonard N. Stern School of Business.

Head, K., \& Ries, J. (2001). Increasing returns versus national product differentiation as an explanation for the pattern of US-Canada trade. American Economic Review, 91(4), 858-876.

Jaud, M., Cadot, O., \& Suwa-Eisenmann, A. (2013). Do food scares explain supplier concentration? An analysis of EU agri-food imports. European Review Of Agricultural Economics, 40(5), 873-890. http://dx.doi.org/10.1093/erae/jbs038

Jouanjean, M. A. (2012). Market Access \& Food Standards: Insights from the implementation of US sanitary and phytosanitary regulation. Institut d'Etudes Politiques de Paris.

Jouanjean, M. A., Maur, J. C., \& Shepherd, B. (2015). Reputation matters: Spillover effects for developing countries in the enforcement of US food safety measures. Food Policy, 55, 81-91.

Kleter, G. A., Prandini, A. L. D. O., Filippi, L. A. U. R. A., \& Marvin, H. J. P. (2009). Identification of potentially emerging food safety issues by analysis of reports 
General discussion

published by the European Community's Rapid Alert System for Food and Feed (RASFF) during a four-year period. Food and Chemical Toxicology, 47(5), 932-950.

Lambert, D. (1992). Zero-inflated Poisson regression, with an application to defects in manufacturing. Technometrics, 34(1), 1-14.

Otsuki, T., Wilson, J. S., \& Sewadeh, M. (2001). Saving two in a billion: quantifying the trade effect of European food safety standards on African exports. Food policy, 26(5), 495514.

United Nations Conference on Trade and Development (UNCTAD). (2005). Methodologies, Classifications, Quantification and Development Impacts of Non-Tariff Barriers. 
Conclusions 


\section{Conclusions}

Trade liberalization agreements signed in the last decades have substantially contributed to increase the integration of the world's agri-food markets. Substantial efforts have been focused on reducing traditional barriers to trade including tariffs and quantitative restrictions. The progressive liberalization of world trade has eased market access, in particular for developing countries. Consequently, trade volumes of agri-food products have grown during the last decades. However, significant regulations to international trade barriers whether than tariffs remain in agri-food products, through the implementation of NTMs, continue to represent a special challenge for exporters in developing countries.

The use of non-tariff measures, mainly SPS, is often justified by the fact that consumers become more and more concerned about the safety and quality standards of imported products. On the other hand, under changing market conditions policymakers can use food safety issues as a tool to disguise domestic producer protection. Hence, NTMs continue to represent an important potential obstacle for exporters in general and for developing countries in particular. In this regard, exporters have to overcome an array of regulatory trade barriers, including the need to satisfy a certain level of quality and safety of agricultural products and other requirements of the importing country (Horton, 1998).

The effect of standards has received an increasing attention of economists and policy makers to identify their implications on trade flows. Previous literature on economics of regulatory barriers has widely examined the impact of NTMs on trade and welfare of the society (Kavallari et al., 2013). The analysis of specific trade policy instruments (GarciaAlvarez-Coque et al., (2009,2010); Cioffi et al., 2011; Santeramo et al., 2014) has focused the attention of mainstream trade literature. Another group of research assessed the policy substitution between tariffs and NTMs in some MPCs (e.g., Tudela-Marco et al., 2014). The literature on determining the factors that influence notifications of non-compliance of SPS and TBT measures is relatively scant, which is mainly due to poor and scarce data. The databases on NTMs are often outdated and uncompleted, and researchers are exploring the possibilities of some sanitary and phytosanitary databases as an alternative source of information. Their main drawback is that they are designed for information and action in the health area, hence not always providing trade information in a consistent way. In fact, the complexity of the conversion of all recorded notifications from verbal form to HS code has 


\section{Conclusions}

limited its use to a few empirical studies. In recent years there have been a few attempts to address this issue. This Thesis contributes to fill this gap by targeting issues not previously investigated and using count model estimation techniques (Poisson, NB, Zero Inflated models) as well as competitiveness measures.

The Thesis is integrated by four independent research articles. The first article, analyzes the scope of the reputation effect over time through extending the concept of reputation to cover a longer time span. The second article's scientific contribution is mainly of an empirical nature, as it targets nuts products. More specifically, it focuses on assessing the Aflatoxin (AF) standards on notifications of these products, the most notified sector. The third research paper seeks to assess the influencing factors on food standard enforcement in the EU, which is a major importer of agri-food products from developing countries, paying attention to Mediterranean countries. Finally, the last article aims at determining the competitiveness of Tunisian agri-food products in respect to Europe and Maghreb before signing DCFTAs.

The methodological approach adopted in the first paper allows accounting for the dynamic effect of reputation over time. It is the main novelty and contribution of this paper. Our research is pioneer in that it investigates how past notifications lagged up to three years can affect the application of SPS measures to EU imports of agri-food products. To this end, we have used two count models based upon RASFF database of EU notifications over the period 1998-2013.

Our empirical findings suggest that EU SPS border controls are affected by reputation. Our results identify product's own reputation -with a relatively stronger effect in the case of one-lagged-year notifications in comparison with two or three-lagged years as the variable that is more relevant in explaining EU notifications. Finally, we find evidence that a country's development level is a key determinant of the integration in the global value chains in terms of complying with EU product safety standards. Consistently, two different patterns have been detected. For the first group of countries (e.g., China, the US, Turkey, Brazil and Argentina), product reputation are relevant but their effects diminish over time, hence indicating that effective efforts have been employed to fix the SPS problems notified previously. Identical to the first group, previous notifications have detrimental effects on current SPS compliance for the second group (e.g., Morocco, Thailand, Vietnam, Ukraine and Egypt) and exports are still burdened by past (bad) performance. This can be explained that 


\section{Conclusions}

these countries lack necessary resources and institutions to fulfill SPS rules implemented by developed countries (Petrey \& Johnson, 1993; Sykes, 1995; Thilmany \& Barrett, 1997).

In the second research article, our primary objective is to examine the behavior of the EU in controlling AF contamination in nuts with respect to food policy changes. These changes implied first tightening and harmonization, and then relaxing of border regulations. As a specific case study, we focus on nuts trade since they represent a group of products that tends to be highly notified. To conduct this analysis, we used RASFF notifications on AF covering the period 1998-2015. Two notable changes in regulations with respect to AF standards have been accounted for in our empirical model. In 2002, the EU harmonized and set stricter standards to control the safety of imported nuts, while the second change was established in 2010 to allow for higher maximum presence of AF based on by Codex less strict standards. With this paper, we contribute to the existing literature by providing a new theoretical framework, based on a political economy approach, to explain the behavior of the EU in controlling AF contamination in nuts in the context of food policy changes.

A theorical framework was adapted in this study departing from a political economy approach and based on the Grossman-Helpman model of political influence (1992). The theorical framework was modified to consider the capacity of exporting countries to meet standards and the path-dependence on previous decisions. This modification was introduced to include dynamicity in the model. Our empirical results show that the number of AF notifications for nuts is affected by the number of alerts and product own reputation, with a relatively stronger effect in the case of alert notifications compared to product and country past reputation. Low performance of exporting countries in trading nuts cannot only be attributed to the adverse impact of the European Union's strict harmonized standard on AF. There are leading and emerging suppliers of nuts who are benefiting from the EU adopted Codex standards such as the United States, Argentina and South Africa. These countries have undertaken important efforts to upgrade the quality of their exports and increasing nuts production with less AF contamination.

The third research paper aims at assessing if the reputation effects can affect the implementation of NTMs, considering RASFF notifications at the EU border. While notifications are affected by specific SPS and TBT problems, however, historical refusals may impact present restrictiveness of NTMs. Four types of reputation effects are considered, namely product, sector, country and region reputations. Checking these effects for the EU case for the first time in the literature is the main contribution of this paper. 
Our empirical findings suggest that the EU notifications are affected firstly by the own reputation of a product and the country reputation, with relatively stronger effect of the reputation built at the product level. Another interesting finding reveals that EU rejections of agricultural and food products from outside Europe are also affected by the import value indicating a possible protectionist behavior. In line with previous literature, we also find evidence that technical and financial resources as well as human capacities would advocate the integration of agro-exporting firms in the global value chains to comply with EU requirements regarding the quality of imported products. Finally, results show no sign of protectionist behaviour by the EU against Mediterranean exporters, even when their export specialization competes with Southern European production (e.g., fruits, vegetables and its preparations). This can be attributed to historical partnership and the geographical proximity which could reflect in a better treatment based upon the NB coefficient for the Mediterranean product reputation.

The last research paper intends to provide an overview about the competitiveness of the Tunisian agri-food sector before signing the Deep and Comprehensive Free Trade Agreement with the EU. Competitive advantage measurement, based on INS data over the 2007-2012 period, has been used for this purpose. The analysis of the Tunisian agri-food sector reveals an important potential of exporting some agri-food products. Recently, Tunisia is facing new challenges in exporting strategic products such as dates and olive oil, underlying the importance of adopting new business and marketing strategies, such as conditioning, packaging or prospecting new markets. However, some agri-food subsectors, mainly animal products, milk and dairy products and cereals, remain unprepared to support the costs of the DCFTA due to their low competitiveness. Hence, Tunisian authorities could propose a progressive trade liberalization strategy with the EU. The main contribution of this research consists of the identification of the products potentially more challenged as a result of the liberalization.

Based on these results, some policy implications as well as recommendations for future studies are proposed along the Thesis. Given the negative relationship between EU import refusals and exporter's GDP per capita, technical and financial resources to ensure quality and safe food are prerequisite to enhance the performance of agro-exporting enterprises particularly in developing countries. This would allow them to comply with EU product safety standards. Therefore, analyzing the measures implemented in different instances can be a fruitful exercise, not only in terms of pure academic research but also as a 


\section{Conclusions}

basis for good policymaking. On the other hand, involving developing country stakeholders in NTMs-setting process through international organizations and bilateral discussions would be of considerable importance to get more harmonization between EU standards and their agrifood suppliers.

More rigorous public policies with pre-export facilities and controls such as warehouses, terminals, roads etc. are needed to enhance compliance with SPS rules and overcome the problem of high level border rejection rates. This is especially useful for agrifood products in general and edible nuts in particular. Nuts trade to the EU remains heavily dependent on restrictive controls of AF carried out by MS, which affect the economy of nuts producers. According to these, many efforts have been devoted by main producers of nuts (e.g., USA, Argentina and South Africa) to avoid AF contamination and enhance the quality of their exports. Another way to improve the exporting performance of developing countries may be achieved through encouraging foreign direct investment in agri-food sector to foster producers' competitiveness by promoting the adoption of adequate varieties with quality control and certification facilities. This may lead to improve the likelihood of acceptability of food offered for importation.

Across the papers included in the Thesis, the product reputation effect has been demonstrated to be a solid element framing SPS compliance in the agri-food trade. Checking whether or not product reputation matters at other major importers' borders can be a relevant research area. Investigating the evolution of reputation effects for different countries in other geographical areas can also help to contrast current results.

Finally, our study provides an opportunity to stress that the RASFF database can be a rich source of detailed information on agri-food trade. Collecting data, through more refined surveys, on exporting companies' perceptions of regulatory constraints as well as the business environment that they face would increase the reliability represented by our results. Such information might contribute to establish a better transparency on NTMs. Providing a solid basis for national and international authorities would be helpful to implement effective tools to avoid adverse trade effects and to effectively address the economics of border regulations. This is left as another pending research issue that merits further attention. 


\section{References}

Cioffi, A., Santeramo, F. G., \& Vitale, C. (2011). The price stabilization effects of the EU entry price scheme for fresh fruit and vegetables. Agricultural Economics, 42(3), 405418.

Garcia-Alvarez-Coque, J. M., Martinez-Gomez, V., \& Villanueva, M. (2009). A trade model to evaluate the impact of trade liberalisation on EU [European Union] tomato imports. Spanish Journal of Agricultural Research, 7(2), 235-247.

Garcia-Alvarez-Coque, J. M., Martinez-Gomez, V., \& Villanueva, M. (2010). Seasonal protection of F\&V imports in the EU: impacts of the entry price system. Agricultural Economics, 41(2), 205-218.

Grossman, G. M. \& Helpman, E. (1992). Protection for sale (No. w4149). Cambridge, MA: National Bureau of Economic Research.

Horton, L. R. (1998). Food from developing countries: steps to improve compliance. Food and Drug Law Journal, 53(1), 139-171.

Kavallari, A., Rau, M.L., \& Rutten, M. (2013). Economic Growth in the Euro-Med Area through Trade Integration: Focus on Agriculture and Food - Regional Impact Analysis, Joint Research Center: Scientific and Policy Report.

Petrey, L. A., \& Johnson, R. W. M. (1993). Agriculture in the Uruguay Round: sanitary and phytosanitary measures. Review of Marketing and Agricultural Economics, 61(3), 433442.

Santeramo, F. G., Capitanio, F., \& Adinolfi, F. (2014). Integrating agricultural risks management strategies in selected EU Partner Countries: Syria, Tunisia, Turkey. Romanian Journal of European Affairs, 14, 22.

Sykes, A. O. (1995). Product standards for internationally integrated goods markets. Washington, DC: Brookings Institution.

Thilmany, D. D., \& Barrett, C. B. (1997). Regulatory barriers in an integrating world food market. Review of Agricultural Economics, 19(1), 91-107.

Tudela-Marco, L., Garcia-Alvarez-Coque, J. M., \& Martinez-Gomez, V. (2014). Are nontariff measures a substitute for tariffs in agricultural trade? Recent evidence from southern Mediterranean countries. Outlook on Agriculture, 43(4), 235-240 


\section{Annex \\ Chapter 3. Programming language $R$ code}

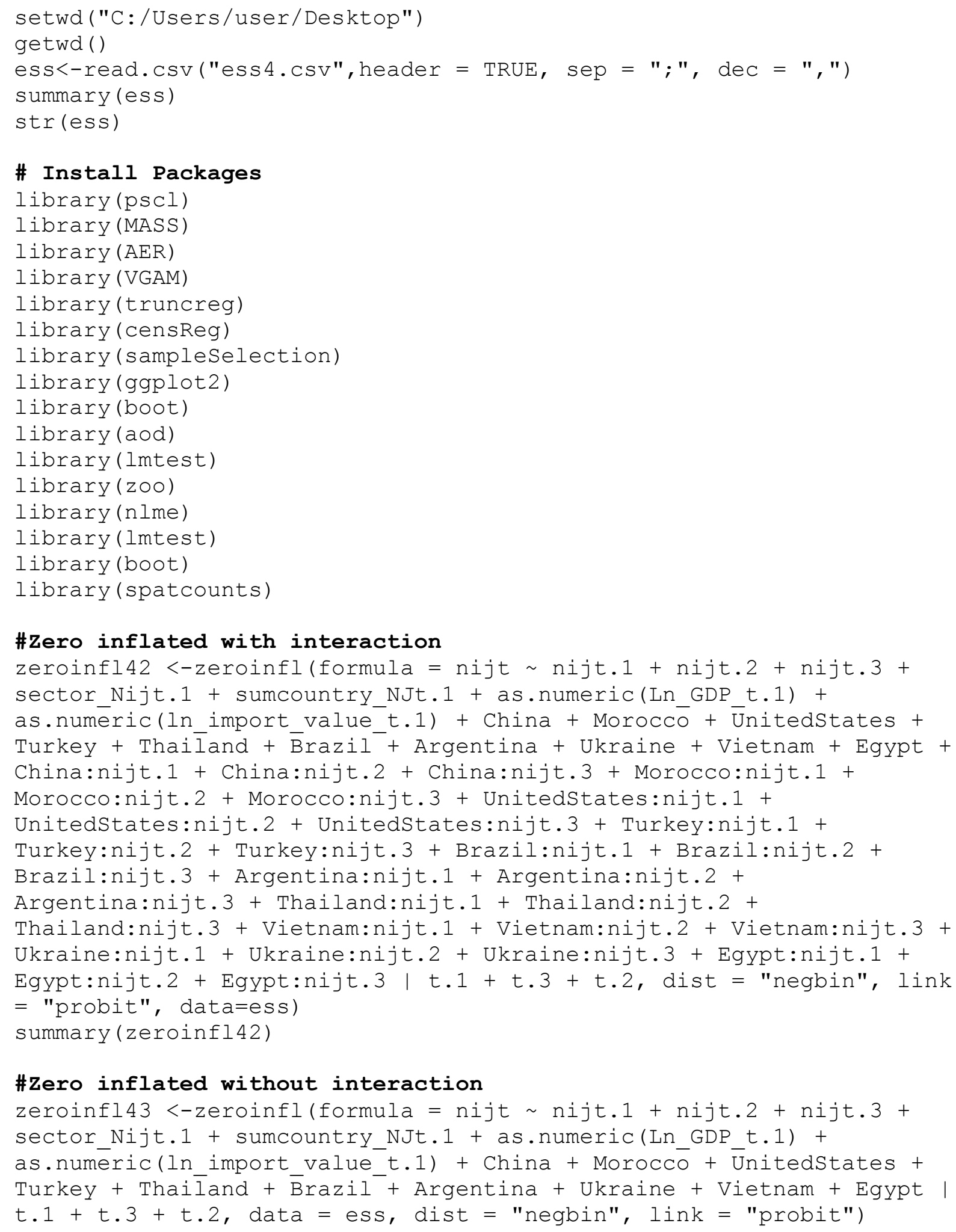

\#Zero inflated without interaction

zeroinfl43 <-zeroinfl (formula = nijt nijt.1 + nijt.2 + nijt.3+ sector_Nijt.1 + sumcountry_NJt.1 + as.numeric(Ln_GDP_t.1) + as.numēric(ln_import_value_t.1) + China + Moroccō $+\bar{U} n i t e d S t a t e s+$ Turkey + Thail̄and + Brazil + Argentina + Ukraine + Vietnam + Egypt t.1 + t.3 + t.2, data = ess, dist = "negbin", link = "probit") 
Annex

summary (zeroinfl43)

\section{\#Negative Binomial with interaction}

Negbin08 <-glm.nb (formula = nijt nijt.1 + nijt.2 + nijt. $3+$ sector_Nijt.1 + sumcountry_NJt.1 + as.numeric(Ln_GDP_t.1) + as.numēic(ln import value t.1) + China + Morocco $+\bar{o}$ UnitedStates + Turkey + Thailand + Brazil + Argentina + Ukraine + Vietnam + Egypt + China:nijt.1 + China:nijt.2 + China:nijt.3 + Morocco:nijt.1 + Morocco:nijt.2 + Morocco:nijt.3 + Unitedstates:nijt.1 + UnitedStates:nijt.2 + UnitedStates:nijt.3 + Turkey:nijt.1 + Turkey:nijt.2 + Turkey:nijt.3 + Brazil:nijt.1 + Brazil:nijt.2 + Brazil:nijt.3 + Argentina:nijt.1 + Argentina:nijt.2 + Argentina:nijt.3 + Thailand:nijt.1 + Thailand:nijt.2 + Thailand:nijt.3 +Vietnam:nijt.1 +Vietnam:nijt.2 + Vietnam:nijt.3 + Ukraine:nijt.1 + Ukraine:nijt.2 + Ukraine:nijt.3 + Egypt:nijt.1 + Egypt:nijt.2 + Egypt:nijt.3, data=ess)

summary (Negbin08)

\section{\#Negative Binomial without intreation}

Negbin09 <-glm.nb (formula = nijt nijt.1 + nijt.2 + nijt.3 + sector_Nijt.1 + sumcountry_NJt.1 + as.numeric(Ln_GDP_t.1) +

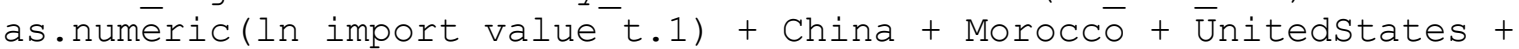
Turkey + Thail and + Brazil + Argentina + Ukraine + Vietnam + Egypt, data $=$ ess )

summary (Negbin09)

\section{\# Nested models}

waldtest (zeroinfl42, zeroinfl43)

vuong(zeroinfl42, Negbin08)

vuong (zeroinfl43, Negbin09)

\section{\# Print Model}

library (texreg)

htmlreg (list(zeroinfl42, zeroinfl43, Negbin08, Negbin09), file="resultsdoc", single.row = TRUE, custom.model.names = c("ZIM1", "ZIM2", "NBM1", "NBM2"), digits=5, bold=0.05, inline.css = FALSE, doctype=TRUE, html.tag=TRUE, head.tag=TRUE, body.tag= TRUE)

\section{Chapter 4. Programming language $R$ code}

\#\#\# Install packages

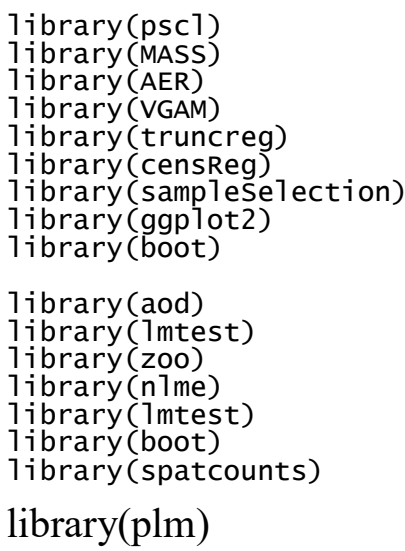


Annex

$\operatorname{library}($ rattle)

library(cluster)

\#\# data reading via ....

setwd("C:/Users/user/Desktop")

$\operatorname{getwd}()$

ess<-read.csv("Database_19.CSV", sep=";", dec=";", header=T)

attach(ess)

zeroinfl00021 <-zeroinfl (formula $=$ Nijt $\sim$ Nijt.1 + Njt.1 + Nij.t.1..K.A. + Nijt.1:Dummy.2002 + Njt.1:Dummy.2002 + Nij.t.1..K.A.:Dumm.2002+

Nijt.1:Dummy.2010 + Njt.1:Dummy.2010+Nij.t.1..K.A.:Dummy.2010+

as.numeric(LnGDP.t.1.) + as.numeric(Ln_Import.t.1.) +

as.numeric (Ln_europ_prod) + as.numeric (Ln_pression_social_t) + Dummy.2010 +

Dummy.2002 + Iran + Turkey + China + United.states + Argentina + Brazil +

Egypt + India + South.africa + Nigeria + Groundnut + Almond + Pistachios I

Nijt.1 + Njt.1 + Nij.t.1..K.A. + as.numeric(LnGDP.t.1.) +

as.numeric(Ln_Import.t.1.) + as.numeric(Ln_europ_prod)

as.numeric(Ln_pression_social_t), data=ess, dist="negbin", link = "logit")

summary (zeroinfl00021)

\section{Chapter 5. Programming language $R$ code}

\# Data reading via...

IB2<-read.cSv("IbtissemDB3 (t-2t-3).cSv", sep="; ", dec=";",

header $=\mathrm{T}$ )

attach (IB2)

str(IB2)

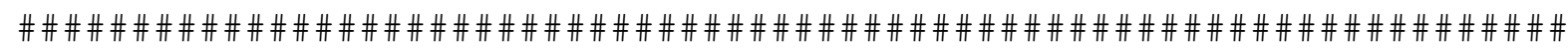

\#\#

\#\#\# Count Models

\#\#\# Data base IB3

\#Zero Inflated Model\#

zeroinfl2<- zeroinfl(formula= nijt nijt.1*Med +nijt.1 +

nijt.2*Med + nijt.2+nijt.3*Med + nijt.3+nIjt.1+nIjt.1*Med+

sommenijt.1_pais +sommenijt.1_pais*Med +

as.numeric( log_gdp_mod)*Med + as.numeric(log_gdp_mod) +

as.numeric (importe dvalue.1001) tas.numeric (importēdvalue.1001) *Med+

$\mathrm{x} 7+\mathrm{x} 8+\mathrm{x} 3+\mathrm{x} 2+\mathrm{x} 6+\mathrm{x} 9+\mathrm{x} 10+\mathrm{x} 11+\mathrm{x} 12+\mathrm{x} 13+\mathrm{x} 15+\mathrm{x} 16+\mathrm{x} 17+$

$\mathrm{x} 18+\mathrm{x} 19+\mathrm{x} 20+\mathrm{x} 21+\mathrm{x} 22+\mathrm{x} 23+\mathrm{Med} \mid \mathrm{t} .1+\mathrm{t} .2+\mathrm{t} .3+\mathrm{nijt.1+}$

nIjt.1+ sommenijt.1_pais,dist="negbin", link="probit", data=IB2)

summary (zeroinfl2)

\#AIC \& BIC Zero Inflated Model\#

AIC (zeroinfl)

AIC (logLik (zeroinfl))

\#Negative Binomial Model\# 


\section{Annex}

negbin2<-glm.nb( nijt nijt.1*Med +nijt.1 + nijt.2*Med + nijt.2+nijt.3*Med + nijt.3+nIjt.1+nIjt.1*Med+ sommenijt.1_pais +sommenijt.1_pais*Med + as.numeric(log_gdp_mod)*Med + as.numeric(log_gdp_mod) + as.numeric(importēdvalue.1001) tas.numeric(importēdvalue.1001)*Med+X7+x8 +x3+x2+x6+x9+x10 $+\mathrm{X} 11+\mathrm{x} 12+\mathrm{X} 13+\mathrm{x} 15+\mathrm{X} 16+\mathrm{x} 17+\mathrm{X} 18+\mathrm{X} 19+\mathrm{x} 20+\mathrm{x} 21+\mathrm{x} 22+$ $\mathrm{x} 23+\mathrm{Med}$, data $=$ IB2)

summary (negbin2)

\#AIC Negative Binomial Model Model\# AIC (negbin)

\section{\#Poisson Model\#}

poisson $<-$ glm(formula= nijt $\sim$ nijt.1*Med +nijt. $1+$ nijt. $2{ }^{*}$ Med + nijt.2+nijt.3*Med + nijt.3+ nIjt.1+nIjt.1*Med+ sommenijt.1_pais +sommenijt.1_pais*Med + as.numeric(log_gdp_mod)*Med + as.numeric(log_gdp_mod) + as.numeric(importedvalue.1001)

+as.numeric(importēdvalue.1001)*Med+x7+x8 +x3+x2+x6+x9+x10 $+\mathrm{x} 11+\mathrm{x} 12+\mathrm{X} 13+\mathrm{x} 15+\mathrm{x} 16+\mathrm{x} 17+\mathrm{x} 18+\mathrm{x} 19+\mathrm{x} 20+\mathrm{x} 21+\mathrm{x} 22+$ $\mathrm{X} 23+$ Med, family=poisson, data=IB2)

summary (poisson)

\#AIC Poisson Model\#

AIC (poisson1)

\#over dispersiontest (poisson)\#

dispersiontest (poisson2, trafo=2) 